\title{
ANÁLISIS: DEFENSA DE LA MANO DE OBRA LOCAL EN LA POLÍTICA PÚBLICA DE EMPLEO DE BARRANCABERMEJA, UNA VISIÓN PARA EL DESARROLLO LOCAL
}

\section{LINA MARCELA MERLANO MARÍN}

UNIVERSIDAD SANTO TOMÁS

FACULTAD DE SOCIOLOGÍA

MAESTRÍA EN PLANEACIÓN PARA EL DESARROLLO

BOGOTÁ, COLOMBIA

2016 


\title{
ANÁLISIS: DEFENSA DE LA MANO DE OBRA LOCAL EN LA POLÍTICA PÚBLICA DE EMPLEO DE BARRANCABERMEJA, UNA VISIÓN PARA EL DESARROLLO LOCAL
}

\section{LINA MARCELA MERLANO MARÍN}

Trabajo de investigación para optar al título de: MAGISTRA EN PLANEACIÓN PARA EL DESARROLLO

DIRECTORA

DORIS YANETH HERRERA MONSALVE

\author{
UNIVERSIDAD SANTO TOMÁS \\ FACULTAD DE SOCIOLOGÍA \\ MAESTRÍA EN PLANEACIÓN PARA EL DESARROLLO \\ BOGOTÁ, COLOMBIA \\ 2016
}




\section{DEDICATORIA Y AGRADECIMIENTOS}

Este trabajo de tesis de grado está dedicado a DIOS, por permitirme respirar cada día. A mi padre y mis hermanos por siempre estar ahí. A mi familia entera por su cariño. A mi madre por ser el motor de mi vida y la persona que inspira todo para ser motivo de orgullo en ella. También lo dedico a Jhon Mario, mi amor, gracias por tu compañía, comprensión, alegría y por estar a mi lado para compartir este momento de felicidad.

Mi sincero agradecimiento a la Universidad Santo Tomás en cabeza de la directora de la Maestría en Planeación Desarrollo Mg. Doris Yaneth Herrera Monsalve, quien además fue mi guía en este proceso de aprendizaje y de investigación; a todo el equipo de docentes que ayudaron en este proceso de formación en cada uno de los semestres cursados.

A mis compañeros de clase por compartir sus saberes, alegría y por su trabajo en equipo, esto fue fundamental para aprender nuevas cosas para la vida y la formación profesional. Gracias a Iván Eduardo Matiz y a Luis Michael Plazas por su amistad, por su compromiso en cada trabajo en equipo, por su disposición y paciencia. 


\section{RESUMEN}

La generación de oportunidades laborales y la defensa de la mano de obra local ha sido para la población del Municipio de Barrancabermeja una prioridad. Desde 1985 están exigiendo al gobierno local que dentro de la dinámica laboral, se prefiera al talento humano del territorio para mejorar las condiciones de vida de sus ciudadanos. Dentro de las competencias municipales el gobierno de turno en 2008 acordó la implementación de la Política Pública de Empleo para formular acciones con el objeto de brindar oportunidades de empleos dignos y decentes a las personas, defender la mano de obra local, apostarle a la formación del talento humano y al desarrollo local. Sin embargo, pasados más de seis años desde la implementación de la Política Pública (PP), y los pobladores consideran que en el municipio aún no se protege la mano de obra local pues no evidencian los resultados y las cifras de desempleo van en aumento 19.9\% (EHB-CER, 2013).

Este trabajo de investigación busca profundizar, mediante un análisis cualitativo, el aporte de la política pública de empleo de Barrancabermeja en la defensa de la mano de obra local como pilar para el desarrollo municipal a partir de las percepciones de los miembros del Comité que hace evaluación y seguimiento de la implementación y cumplimiento de la PP de empleo.

Los resultados obtenidos durante el desarrollo y análisis de este proyecto dan cuenta de las dificultades que se presentan al implementar políticas públicas, y de la necesidad que en el municipio se generen políticas territorizalizadas, inmersas en un nuevo modelo de desarrollo local con el que no sólo se defienda la mano de obra sino con el que se establezcan nuevas dinámicas en otros sectores productivos y económicos, que permitan un uso responsable de los recursos naturales y el bienestar social de las comunidades.

Palabras claves: políticas públicas; empleo y trabajo como derecho; desarrollo local y economía extractiva. 


\section{ABSTRACT}

The creation of employment opportunities and the defense of local labor has been a priority for Barrancabermeja's population. Since 1985 they are demanding to local government that human talent of the territory be preferred in work dynamics in order to improve the living conditions of its citizens. In 2008, current government agreed to implement the Public Employment Policy to formulate actions in order to provide opportunities for dignified and decent people jobs, to defend the local workforce, to bet on training human talent in the region and local development. Nevertheless, more than six years after the implementation of this Public Policy (PP), villagers believe that local goverment doesn't protect local workforce because they cannot see any result and unemployment numbers are rising $19.9 \%$ according to the Household Survey Centro de Estudios Regionales del Magdalena Medio (CER) in 2013.

This research seeks to deepen, through a qualitative analysis, the contribution of public employment policy Barrancabermeja in the defense of the local workforce as a pillar for municipal development from the perceptions of members of the Committee that makes assessment and monitoring of the implementation and enforcement of the PP employment.

The results obtained during the development and analysis of this project show the difficulties encountered in implementing public policies, and the need for the municipality of generating policies attending the territory, immersed in a new local development model to defend workforce and, further, to establish new dynamics within other productive and economic sectors that allow a responsible use of natural resources and social welfare of communities.

\section{KEYWORD}

Public politics; employment and work as a right; local development and extractive economy. 


\section{Tabla de contenido}

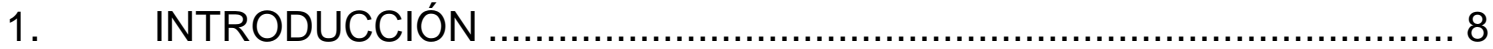

2. PLANTEAMIENTO DEL PROBLEMA, OBJETIVOS Y JUSTIFICACIÓN DE LA INVESTIGACIÓN ........................................................ 12

2.1. Planteamiento del problema........................................................ 12

2.2. Objetivos de la investigación ........................................................ 15

2.2.1. Objetivo general .................................................................... 15

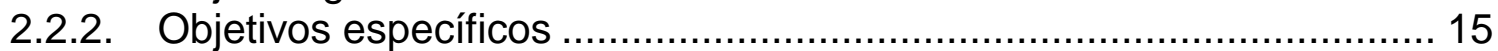

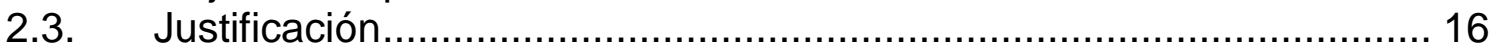

3. MARCO CONCEPTUAL ….................................................... 18

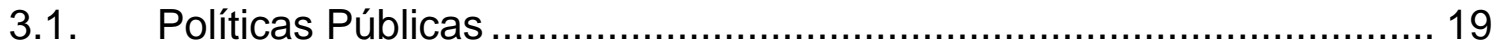

3.1.1. Implementación de política pública ……….................................... 25

3.1.2. Territorialización de la política pública.............................................. 29

3.2. Trabajo y Empleo: una breve conceptualización según la OIT y el contexto colombiano. .................................................................. 31

3.2.1. Conceptualización según la OIT sobre trabajo y empleo ..................... 33

3.2.2. El trabajo/empleo en el contexto colombiano .................................... 36

3.3. Definiciones: Mano de obra calificada y no calificada ........................ 38

3.4. El Desarrollo y la dimensión del desarrollo local: implicaciones en materia de empleo, aproximaciones para su definición ................................... 38

3.4.1. ¿Qué se entiende por Desarrollo? .............................................. 38

3.4.2. El Desarrollo Local ........................................................................ 41

3.4.3. El Desarrollo para el empleo …................................................... 45

3.5. Economías Extractivas: en el sector petróleo .................................. 49

3.5.1. Dinámica laboral del Gas y el petróleo: ¿qué las diferencia de las demás dinámicas?

4. MARCO CONTEXTUAL ........................................................... 58

4.1. Una mirada al municipio de Barrancabermeja, Santander .................. 58

4.1.1. Ubicación geográfica de Barrancabermeja ...................................... 58

4.1.2. Características demográficas de Barrancabermeja .........................6 60

4.1.3. Caracterización del Comité de Política Pública de Empleo.................. 67

4.1.4. Niveles de desempleo de Barrancabermeja......................................69 69

4.1.5. Fuentes de empleo que existen en Barrancabermeja ........................ 74

5. MARCO NORMATIVO ............................................................ 76

5.1. Convenios firmados con la OIT para la protección laboral de Colombia ............................................................................... 76

5.2. Principales leyes y normas generadas en Colombia para la protección laboral en el sector petrolero ....................................................... 77

5.3. Acuerdos y decretos municipales generados en Barrancabermeja para la defensa de la mano de obra local y la puesta en marcha de la política pública de empleo en la ciudad ......................................................... 84

6. MARCO METODOLÓGICO ….................................................... 86 


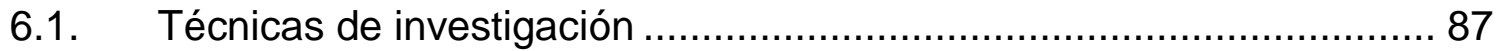

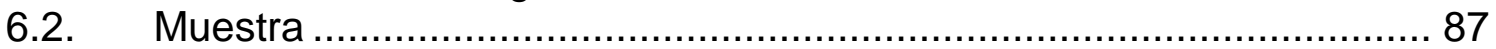

7. MARCO DE ANALSIS .......................................................... 90

7.1. Surgimiento, contexto y actores que formularon la Política Pública de empleo en Barrancabermeja...................................................... 102

7.2. Definiciones de Defensa de la mano de obra local ......................... 106

7.3. La implementación de la Política Pública de empleo en Barrancabermeja

7.3.1. Aciertos, desaciertos y retos que enfrenta la Política Pública de empleo en Barrancabermeja................................................................ 124

7.3.2. Cambios o modificaciones para realizar en la Política Pública de empleo en Barrancabermeja................................................................... 129

7.3.3. El desarrollo local a través de la implementación de la Política Pública de empleo en Barrancabermeja ..................................................... 131

7.4. La plataforma de empleo como herramienta para evitar la intermediación de laboral en Barrancabermeja ..................................................... 133

7.5. Divulgación y comunicación de la Política Pública de empleo en Barrancabermeja ................................................................ 136

8. CONCLUSIONES Y RECOMENDACIONES ….......................... 140

9. REFERENCIAS BIBLIOGRÁFICAS ........................................ 147

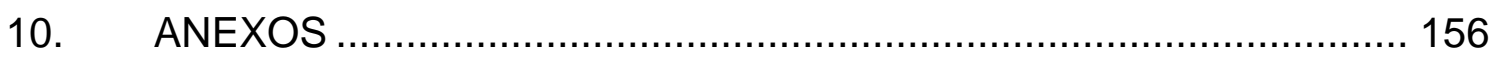

\section{Índice de Tablas}

Tabla 1: Tipos de extracción y destino de recursos naturales ......................... 50

Tabla 2: Planes de Desarrollo - Periodo de estudio 2008- 2014 .................... 63

Tabla 3. Encuesta a Hogares urbano-rural del municipio de Barrancabermeja

Tabla 4. Encuesta a Hogares urbano-rural del municipio de Barrancabermeja 72 Tabla 5. Cuadro comparativo según cifras del Fenómeno de Empleo en Barrancabermeja ..................................................................................... 73 Tabla 6, Actores entrevistados, miembros del Comité de Política Pública de Empleo de Barrancabermeja .............................................................. 88 Tabla 7. Cuadro comparativo según cifras del Fenómeno de Empleo en Barrancabermeja …........................................................................... 140

\section{Índice de gráficas}

Gráfica 1: Tasa desempleo en Colombia, Abril 2014 (Dane) .......................... 37

Gráfica 2. Mapa municipio de Barrancabermeja (Santander) .......................... 59

Gráfica 3. Encuesta de Hogares urbano - rural de Barrancabermeja .............. 70 


\section{INTRODUCCIÓN}

El Estado como garante de derechos fundamentales de los ciudadanos -entre estos el derecho al trabajo consagrado en la Constitución de 1991, ratificado a través de convenios internacionales y la jurisprudencia constitucional- debe enfatizar en acciones que, desde sus instituciones, permitan dar cumplimiento al objetivo de brindar opciones de empleos dignos y decentes a las personas, al igual como lo plantea la Ley 715 de 2001 en los artículos 74 y 76 , cuando define las competencias de los departamentos en coordinación con los municipios, por ende, Barrancabermeja estableció una política pública de empleo en el año 2008 para ser gestor planificador de su propio desarrollo local.

De otra parte, desde hace más de dos décadas el país posicionó al sector de la minería e hidrocarburos como motor del crecimiento económico nacional. El gobierno de turno, en cabeza del presidente Juan Manuel Santos Calderón (2010-2014), activó la locomotora minera para el desarrollo sin que hasta el momento se deriven de ella ganancias en pro del beneficio público. Por el contrario, dicha locomotora ha propiciado la devastación de los recursos naturales y el empobrecimiento de las comunidades en el entorno de las zonas de explotación, que esperan oportunidades laborales dentro de este tipo de extracción.

Frente a esta lógica, Colombia se encuentra bajo un modelo de desarrollo que busca el crecimiento económico, sin embargo "[...] ha generado conflictos sociales, ambientales, económicos y culturales en varias regiones del territorio nacional' (Negrete, 2013 p. 23). 
Más de una tercera parte del territorio continental de Colombia cuenta con título minero, está solicitado para titulación o está destinado para el desarrollo minero a través de las áreas estratégicas mineras, lo que de por sí es una cifra alarmante, más aún cuando Colombia es el país con mayor biodiversidad por kilómetro cuadrado del planeta, y cuando las normas e instrumentos que regulan estas actividades no son lo suficientemente efectivas para proteger, resguardar y mantener de manera adecuada los recursos naturales renovables y los derechos fundamentales de los habitantes del país. (Negrete, 2013, p. 24)

De acuerdo a lo anterior, Colombia es mayoritariamente extractiva con respecto a sus recursos naturales; esto va en contravía del mandato de la Constitución Política de 1991, con la que el país adoptó el modelo del desarrollo sostenible, con el que se busca compatibilizar el desarrollo económico, la elevación de la calidad de vida y el bienestar social, con la preservación del medio ambiente, sin agotar la base de los recursos naturales renovables, en condiciones que permitan a las generaciones futuras vivir en forma digna y promover su propio desarrollo, según lo previsto en el artículo 3 de la Ley 99 de 1993.

Es preciso definir al extractivismo como "un tipo de extracción de recursos naturales, en gran medida con un volumen o alta intensidad, y que están orientados esencialmente a ser exportados como materias primas sin procesar, o con un procesamiento mínimo" (Gudynas, 2013, p.3). Generalmente se asocia el extractivismo con una "industria" para crear imaginarios en las personas, ya que al denominarla de esta manera se apunta a evocar imágenes de fábricas repletas de obreros con lo que se busca lograr la adhesión de la opinión pública, sin que esto resulte cierto porque dichas fábricas no existen, la demanda de empleo de esos emprendimientos es escaza y el valor agregado limitado. Este tipo de extracción sólo deja riqueza para los consorcios internacionales y el incumplimiento de normas sociales y ambientales para las comunidades. 
Bajo estos preceptos se inscribe el presente trabajo de investigación, el cual busca analizar mediante un estudio de caso la política pública de empleo y la generación de desarrollo local como apuesta por mejorar las condiciones de vida de las comunidades porteñas en el sector petrolero de Barrancabermeja, a partir de las percepciones de los integrantes de dicho comité.

Para el abordaje del estudio se establecieron siete apartados, en los que se plantea el problema de investigación que busca responder a las siguientes preguntas: ¿Qué tanto la Política Pública de Empleo ha aportado a la defensa de la mano de obra local para el sector petrolero?, ¿Cuáles son las percepciones de los miembros del Comité frente a la implementación de la política Pública de Empleo? Estos interrogantes permitieron dar cuenta de los aciertos, desaciertos y retos en la implementación de acciones en el municipio acorde con las competencias del mismo.

La estructura de la investigación contempla elementos conceptuales importantes para analizar las políticas públicas, su implementación y territorialización; también algunas interpretaciones sobre el trabajo como derecho basadas en la visión de la Organización Internacional del Trabajo (OIT) y el Estado colombiano, especificando aspectos involucrados como mano de obra calificada y no calificada; se expone la significación del desarrollo, las dimensiones del desarrollo local y el desarrollo para el empleo como ejes trascendentales para la consolidación de un nuevo modelo de apuesta por una visión compartida en el territorio. Finalmente, se argumentan las dinámicas laborales que se derivan de las economías extractivas, especialmente en el sector petrolero, y las consecuencias que impactan en las comunidades involucradas. 
La metodología se realizó a partir de enfoque cualitativo de tipo explicativo, con el cual se logró hacer un abordaje, una interpretación y un análisis de la información generada como resultado del diálogo con los 12 integrantes del Comité de la Política Pública de Empleo de Barrancabermeja, para conocer lo que piensan, sienten y esperan de esta problemática. El periodo de análisis está comprendido entre el 2008 al 2014, el trabajo de campo se realizó en septiembre de 2014. Además, se contrastaron con documentos oficiales.

Finalmente, algunos de los resultados dan cuenta de la necesidad de rediseñar la Política Pública de Empleo para generar oportunidades laborales en la sociedad porteña: es importante construir una política enfocada al desarrollo económico, que involucre y potencie nuevos sectores productivos, distintos a la dinámica petrolera. El municipio podrá plantear un modelo de desarrollo local en el que participe activamente la ciudadanía para trazar una visión de territorio compartido. 


\section{PLANTEAMIENTO DEL PROBLEMA, OBJETIVOS Y JUSTIFICACIÓN DE LA INVESTIGACIÓN}

\subsection{Planteamiento del problema}

La generación de oportunidades laborales y la defensa de la mano de obra local es para la población del Municipio de Barrancabermeja una prioridad. Desde 1985 están exigiendo al gobierno local que dentro de la dinámica laboral de la región, se priorice el talento humano del territorio para mejorar las condiciones de vida de sus ciudadanos. Sin embargo, pese a que desde esa época se firmó el Acuerdo 026 para evitar la discriminación laboral, los esfuerzos institucionales no han arrojado los resultados deseados por las comunidades.

Los antecedentes dan cuenta de una anterior regulación -a través del Acuerdo 026 de 1985- en donde se crea un mecanismo de vigilancia con el que se buscaba la protección de la mano de obra local para velar por los intereses de la comunidad, y siendo una competencia territorial tal como se plantea en la Ley 715 de 2001 en los artículos 74.15 y 76: "participar en la promoción del empleo y la protección de los desempleados" y "promover el empleo y la protección a los desempleados" respectivamente. Estas normas vigentes no lograban solucionar la desprotección a la que están sometidos los ciudadanos porque se cree que la mayoría de empresas petroleras contrataban personas foráneas al territorio, en tanto, desconocían la realidad social de la región y del municipio. 
Esta regulación aún vigente en el territorio, se ratifica posteriormente con el Acuerdo 005 de 2008, con el objetivo de garantizar la vinculación de las personas del municipio a las diferentes ofertas laborales locales y nacionales presentes en el Puerto Petrolero en tanto, para generar ingresos y disminuir las cifras de desempleo que en el año 2007 se estimaba según el CER en 21,2\%, y a nivel nacional se calculaba en $10.6 \%$ para la misma fecha (Almario, 2010). Posteriormente, con la aplicación de las Encuestas de Hogares aplicadas por el CER en los años 2011 y 2013 el desempleo en el puerto petrolero se estimaban en $16.2 \%$ y $19.9 \%$ y un subempleo del $24.1 \%$ y $26.0 \%$ respectivamente, comparándolo con las cifras de desempleo nacional en 2011 fue de $10.8 \%$ y en 2013 de 9.65\% (CER, 2013). En la actualidad, el gobernador de Santander, Didier Tavera Amado, informó que el índice de desempleo en el puerto petrolero está en el $30 \%$, debido a los bajos precios del petróleo y el fenómeno del niño (W Radio, 2016).

Teniendo en cuenta la situación del municipio para la época, en el gobierno del alcalde Carlos Alberto Contreras López (2008 - 2011) se formuló la política pública para defender la mano de obra local, implementar estrategias para la generación de empleo y apostarle a la formación del talento humano. Desde ahí se han realizado acciones para la ejecución de esta política pública, como la conformación e instalación del Comité encargado de hacer evaluación y seguimiento a la implementación y cumplimiento de la PP, entre otras estrategias, que no han logrado evitar el inconformismo de la población respecto del tema.

Uno de los problemas más comunes, según lo expuesto en el actual Acuerdo Municipal (005 de 2008), es la intermediación laboral. Este documento refiere que se realiza por presión de diferentes factores, incluso actores armados al margen de la Ley; por esta razón, se consolidó la Plataforma del Servicio Nacional de Aprendizaje (SENA) como herramienta para las postulaciones de las personas 
interesadas en las diferentes vacantes que genera el sector petrolero. Con la reglamentación del Servicio Público de Empleo implementado por el gobierno nacional a través del Ministerio de Trabajo (Decreto 0722 de 2013) se establecen nuevos operadores para ejercer la actividad de intermediación laboral, es ahí cuando surgen otras plataformas en la ciudad para brindar transparencia en los procesos de selección y vinculación del personal. El Ministerio del Trabajo tomó como modelo la PP de Empleo de Barrancabermeja para convertirla en plan piloto para el resto del país.

Sin embargo, han pasado más de seis años desde la implementación de la Política Púbica de Empleo en Barrancabermeja y aún los pobladores consideran que en el municipio no se protege la mano de obra local pues no evidencian los resultados, por tanto, las cifras de desempleo van en aumento y no se generan nuevas oportunidades laborales que permitan mejorar las condiciones de vida y aumentar el desarrollo de la ciudad.

Las anteriores son algunas de las motivaciones para plantear este trabajo de investigación. Es importante establecer cuál es el aporte de la política pública por la defensa de la mano de obra local como pilar para el desarrollo municipal, qué ha sucedido durante la etapa de implementación de la Política Pública de Empleo, desde la opinión de quienes están vinculados directamente en el Comité que hace evaluación y seguimiento; además, conocer sus resultados, desaciertos y los retos que ésta tiene con la ciudad.

El análisis centra su atención en el componente Defensa de la Mano de Obra Local para el sector petrolero, debido a que se "cree" es la principal fuente de empleo y generación de recursos en Barrancabermeja. Lo anterior da luces para conocer el enfoque de desarrollo al que le apuesta la ciudad, donde se genera una fuerte economía extractiva (explotación del petróleo) de la que muchos 
integrantes de la comunidad buscan vincularse y otros se quejan por no tener acceso a la contratación aduciendo que esto se debe al hecho de "ser locales". Con el análisis de la política pública de empleo desde las percepciones de los actores que hacen parte del Comité de Política Pública de Empleo se busca dar respuesta a estas inquietudes. De acuerdo a lo anterior, surgen las siguientes preguntas de investigación:

¿Qué tanto la Política Pública de empleo ha aportado en la defensa de la mano de obra local para el sector petrolero? y ¿Cuáles son las percepciones de los miembros del Comité frente a la implementación de la Política Pública de Empleo de Barrancabermeja?

Este estudio permitirá reconocer la política y las percepciones de los miembros del Comité de PP y para esto se plantearon los siguientes objetivos:

\subsection{Objetivos de la investigación}

\subsubsection{Objetivo general}

Analizar la Política Pública de Empleo en Barrancabermeja y su aporte en la defensa de la mano de obra local como pilar para su desarrollo municipal.

\subsubsection{Objetivos específicos}

- Indagar sobre la política pública de empleo y las percepciones de las personas que hacen parte del Comité Municipal sobre la defensa de la mano de obra local y cómo ésta influye en su propio desarrollo. 
- Caracterizar la manera en que los diferentes miembros del Comité Municipal consideran que la Política Pública de Empleo de Barrancabermeja ha influido en el desarrollo local del territorio.

- Identificar en el proceso de implementación, los aciertos, desaciertos y retos de la Política Pública de Empleo de Barrancabermeja, de acuerdo a las percepciones de los integrantes del Comité Municipal.

\subsection{Justificación}

La pertinencia del presente estudio radica en profundizar sobre las políticas públicas de empleo para la generación de un modelo de desarrollo local que permita generar otras dinámicas productivas, de manera que se mejoren las condiciones de vida de las comunidades.

Con este estudio de caso cualitativo sobre el análisis de la política pública de empleo de Barrancabermeja a partir de las percepciones y opiniones de las personas que integran el Comité Municipal y que están involucrados con evaluación y seguimiento de la implementación y cumplimiento de PP, se busca establecer el aporte que ésta ha dado a la defensa de la mano de obra local y generación de oportunidades como pilares fundamentales para el desarrollo local. El análisis resulta relevante porque es indispensable que las comunidades tengan acceso al empleo para potenciar sus capacidades y forjar bienestar social.

Con este análisis se pretende demostrar que este enclave petrolero de economía extractivista en el que está inmerso el municipio las oportunidades laborales no serán suficientes para cumplir con las exigencias de las 
comunidades; además, precisa dinamizar otros renglones productivos para que la economía sea sostenible, dar un buen uso a los recursos naturales y se reinvierta en la gente; este estudio es pertinente en el programa de Maestría en Planeación para el Desarrollo, en tanto, la línea de investigación de desarrollo, políticas públicas y planeación participativa, plantea la discusión y los retos de la territorialización de las políticas públicas, en diálogo con los actores sociales en el territorio, y cómo desde los modelos de economía extractiva afectan el desarrollo local.

Es preciso advertir que desde 1985 la comunidad porteña ha demandado del gobierno municipal la preferencia de la mano de obra local en los proyectos que genera el petróleo. Tanto así que en el año 2008 el alcalde de turno Carlos Alberto Contreras López (2008 - 2011) y las fuerzas vivas de la sociedad lograron que el Concejo Municipal firmara el Acuerdo 005 de 2008 con el que se establece la Política Pública de Empleo de la ciudad. Sin embargo, han pasado más de seis años y la PP no ha generado los resultados que la comunidad reclama. Resulta útil establecer los factores que influyen en esta problemática. 


\section{MARCO CONCEPTUAL}

Las políticas públicas son una herramienta fundamental para la gestión institucional y la gobernanza. De su buen desempeño dependen específicamente las soluciones a los problemas sociales que demandan los territorios en cualquiera de los aspectos que los actores deseen transformar. En ese sentido las políticas pueden ser la catapulta para la generación de acuerdos, programas y proyectos con el interés de resolver los conflictos existentes. La formulación de las políticas públicas exige pensar desde el territorio, con la participación activa de diversos actores políticos, técnicos y sociales para que su puesta en marcha facilite la ejecución y obtención de los resultados planteados.

En este apartado se hace un recorrido conceptual sobre las políticas públicas, su evolución, implementación y territorialización, específicamente en el contexto de la política pública de empleo de Barrancabermeja como una estrategia para defender la mano de obra local del territorio.

Este proyecto de investigación presenta interpretaciones sobre el trabajo como derecho, teniendo presente la visión de la OIT y del Estado colombiano, conceptualizando aspectos que están implícitamente involucrados con la temática como mano de obra calificada y no calificada.

Finalmente, se presentan algunas definiciones sobre desarrollo local y las apuestas que se generan entorno a las dinámicas laborales que se derivan de 
las economías extractivas, específicamente para el sector petrolero, de manera que se evidencia un impacto en las comunidades involucradas.

\subsection{Políticas Públicas}

Definir conceptualmente lo que es una política pública implica reconocer la variada y amplia existencia de términos que dan cuenta de su significado en la bibliografía asociada al tema, como lo argumenta Ordoñez (2013 p. 27) quien indica que en muchos países el término no tiene una traducción correcta y esto hace que sea mal interpretado o que tenga una definición variada de acuerdo al contexto y circunstancia en la que se aplique su significado.

Mejía (2012) interpreta el término política pública como dos vocablos que se complementan y los define por separado para producir la siguiente comprensión conceptual:

Por una parte, lo político y, por la otra, lo público. La palabra política posee a su vez un carácter polisémico referido a la esfera de lo político, la actividad política y la acción pública (Müller, 1994). Hablar de la esfera de lo político supone la distinción entre la sociedad civil y el mundo de lo político; la política pasa a ser la esfera que potencialmente puede dar sentido a las demás dado que es la que funda la existencia de la agrupación como tal al definir la existencia de otro. La actividad política tiende a expresarse en la interacción entre los partidos políticos, la obtención de puestos políticos y las formas de movilización. Por último, la acción pública, se refiere aquellos dispositivos políticos y administrativos coordinados alrededor de objetivos comunes. (Mejía, 2012 p. 145)

Definir estos conceptos permite plantearse una idea general sobre política pública para entenderla como una herramienta de gobierno y de participación 
social que procura el bienestar de las comunidades en los territorios donde se ejecuta.

En la actualidad, algunas definiciones de política pública giran en torno a las acciones ejercidas por el gobierno en función de su quehacer:

Entiendo por política pública el conjunto de decisiones, acuerdos y acciones realizadas por un grupo de autoridades públicas, con o sin la participación de los particulares, encaminadas a solucionar o evitar un problema definido como relevante, y a seleccionar, diseñar e implementar los instrumentos que permitan cumplir sus objetivos. La política pública hace parte de un ambiente determinado, busca modificar o mantener ese ambiente, y puede producir o no los resultados esperados. (Velásquez, 2009, p. 156)

En cambio, otros pensadores consideran que, aunque las políticas públicas son decisiones que sólo son tomadas por los gobernantes, estos pueden involucrar otros actores no públicos en sus decisiones. Para Aguilar:

Una PP es básicamente una acción intencional, orientada a la realización de ciertos objetivos públicos deseados, y una acción causal, que se considera idónea para efectuar los objetivos aspirados, transformando así el resultado deseado en un resultado esperado, es decir, en un hecho cuyo acontecimiento puede esperarse razonablemente que ocurra por cuanto sería el efecto de la acción decidida. (Aguilar, 2008, p.8)

Para Lahera (2008), citado por Mejía (2009, p.145) las políticas públicas son "flujos de información relacionados con un objetivo público definido en forma democrática; esta democracia involucra al ciudadano poniéndolo en un puesto importante en la consecución de objetivos políticos determinados en las esferas de decisión social". Mientras que para Vargas $(2007$, p.85) la política pública es "el conjunto de iniciativas, decisiones y acciones del régimen político frente a situaciones socialmente problemáticas". Por su parte Cuervo (2007, p.79) señala 
que las políticas públicas son "el flujo de decisiones en torno de un problema que ha sido considerado público y ha ingresado en la agenda del Estado".

Retomando a Ordóñez (2013, p.28), el autor hace un recorrido histórico del concepto a partir de las décadas del 50 y 60, época en la que las políticas públicas eran consideradas como variables que dependían de la actividad política porque se suponía que eran el resultado o la consecuencia directa de la misma. Es en la década del 70 donde apareció un interés por estudiar la acción pública y la política pública se forjó como un concepto y un objeto de estudio aparte. Desde entonces varios estudiosos en el tema han conceptuado al respecto.

Algunos de los enfoques con los que se interpreta la política pública inician con la tendencia pragmática (Ordóñez, 2013) utilizada especialmente en Norteamérica, en la que existe una forma de ver el concepto desde la orientación utilitarista: se conceptualizan las políticas públicas como cualquier acción de gobierno que busca dar solución a un problema público; éstas definiciones se encuentran en Dubnick y Bardes (1983), Kraft y Furlong (2007) y Anderson (2003).

Las concepciones europeas tienen definiciones en las que se pone énfasis en una serie de procedimientos específicos, en la naturaleza coherente y consciente de la acción pública o en el planteamiento de ciertos objetivos. Algunos autores destacados en esta línea son: Hogwood (1984), Elau y Prewitt, Muller y Surel (1998), Larrue (2000) y Velásquez (2009).

En el ejercicio de estudiar y definir las políticas públicas algunos de los autores colombianos que presentan propuestas al respecto son: Salazar (2008, p.45), Vargas (1997, p.57), Cuervo (2007, p.82) entre otros. Particularmente la conceptualización del profesor Roth (2002) plantea sobre política pública: 
Un conjunto conformado por uno o varios objetivos colectivos considerados necesarios o deseables y por medios y acciones que son tratados, por lo menos parcialmente, por una institución u organización gubernamental con la finalidad de orientar el comportamiento de actores individuales o colectivos para modificar una situación percibida como insatisfactoria o problemática. (Roth, 2002, p. 14)

Existen otros autores que definen las políticas públicas desde los métodos utilizados en la formulación e implementación (Ordoñez, 2013, pp. 30-31) como son: Jenkins (1978) y May, reseñado por Patton y Sawicki (1993).

La definición que realiza Ordoñez (2013, p.31) propone una conceptualización operacional alternativa que integre el conocimiento, la voluntad política y los recursos disponibles como ejes fundamentales para sacar adelante los objetivos sociales que se buscan en la política pública. Para este autor explorar la perspectiva del conocimiento dentro de las PP es poco común, pero es una alternativa con un significado distinto según lo conocido anteriormente por los otros autores, que daría luces para trabajar por las acciones que se emprenden dentro de éstas. Para esto se referencia a Dror (1971) quien señala:

La política pública es una selección consciente entre varias alternativas para conducir a la sociedad, una "supradisciplina orientada a la búsqueda del aprovechamiento de la elaboración de políticas" (Aguilar, 2009), o como un intento por definir y estructurar una base racional para la acción o la inacción, en donde "tener" una política pública es tener, además, de los recursos necesarios y la voluntad alineada, razones o argumentos que soportan una forma de entender los problemas y sus soluciones. Se habla de viabilizar y no de garantizar, pues reconocemos el valor de la incertidumbre. (Citado por Ordoñez, 2013, p. 32) 
Luego de presentar varias definiciones de otros autores, Ordoñez (2013) considera que la política pública es fundamental para las sociedades actuales y hace su propia conceptualización desde una propuesta alternativa de definición operacional:

La política pública es el conjunto de acciones implementadas en el marco de planes y programas gubernamentales diseñados por ejercicios analíticos de algún grado de formalidad, en donde el conocimiento, aunado a la voluntad política y los recursos disponibles, viabiliza el logro de los objetivos sociales. (Ordoñez, 2013, p. 32)

Finalmente, el autor reconoce la existencia de otros elementos comunes que son necesarios tener en cuenta y facilitan la identificación de lo que constituye una política pública, como son: el criterio procedimental, el criterio orgánico y el criterio material. Todo lo anterior tiene que ver con las decisiones tomadas para lograr un propósito particular, la posibilidad de participación de actores diferentes dentro del proceso y las acciones concretas materiales o simbólicas para generar un impacto y producir resultados dentro de la política pública respectivamente.

Son múltiples las definiciones y gran diversidad de visiones de quienes han estudiado este complejo tema. Es necesario analizar las políticas públicas como proceso, como un acto de toma de decisiones compartidas con la participación activa de la comunidad, con la voluntad política de sacar adelante soluciones para los problemas que ponen de manifiesto las necesidades de la sociedad. Es una manera real en la que se logra fortalecer la relación entre el Estado y la sociedad civil; un espacio para la interacción de los actores, un paso a paso, un proceso que debe ser vigilado y evaluado de principio a fin y en cada una de sus fases. Es indispensable que exista una retroalimentación que permita tomar nuevas decisiones para corregir y avanzar, de manera que se puedan concretar los resultados planteados en la política pública, de lo contrario sería un muy buen documento sin hechos reales y sin impactos para mostrar. 
En consecuencia, luego de un intento por comprender conceptualmente el significado de política pública cabe la pregunta ¿Qué se entiende por política pública de empleo? En términos generales se puede argumentar, valiéndose de los planteamientos anteriores, que:

...es la construcción colectiva de acuerdos y compromisos políticos y ciudadanos para la garantía del derecho al trabajo como un eje potenciador del desarrollo integral de los seres humanos, esto permite que las personas tengan opciones de participar en las actividades de producción y prestación de servicios de la sociedad y en los beneficios obtenidos mediante estas actividades conjuntas en una medida que garantice un nivel de vida adecuado. (International Human Rights Internship Program, 2000, p. 20)

Las políticas públicas de empleo en Colombia, de acuerdo con el cumplimiento del artículo 25 de la Constitución Nacional de Colombia, deben garantizar a las personas en el país su acceso al mercado laboral, además de generar trabajos decentes y dignos en los que se fortalezcan las aspiraciones personales, se satisfaga la prestación de los servicios básicos y se generen mejores oportunidades para el desarrollo integral del ser, por tanto, la política pública de empleo de Barrancabermeja es una política de tipo regulatoria ${ }^{1}$ que exige el cumplimiento en el municipio a las organizaciones nacionales e internacionales, públicas o privadas para garantizar la defensa de la mano de obra local calificada y no calificada, la generación de ingresos y el desarrollo de la ciudad con el objetivo de disminuir los altos índices de desempleo, entre otros problemas sociales que perturban el orden público, la convivencia pacífica, la seguridad ciudadana y la calidad de vida de las personas en el territorio.

1 Según Theodore J. Lowi, una política regulatoria es el sistema racional de instrumentos jurídicos que emplea un Estado para establecer obligaciones y derechos con el propósito de normar la conducta de los particulares y del gobierno para la protección de intereses sociales legítimamente aprobados (1964, p.16). 
En ese sentido las políticas públicas de empleo en el país deben ayudar a: bajar las tasas de desempleo que según el Departamento Administrativo Nacional de Estadística (DANE) se situaron para el año 2015 en $8.9 \%$ y para enero de 2016 subió a 11.9\%, según la fuente oficial por la desaceleración de la economía; regular la existencia de un sector informal que de acuerdo al DANE está en $47,7 \%$; eliminar la discriminación que el mercado laboral efectúa contra las mujeres (la ocupación de hombres $75,7 \%$ y $56,1 \%$ para las mujeres según La Gran Encuesta Integrada de Hogares realizada por el DANE en noviembre de 2015); asegurar empleo o mejorar las condiciones de los jóvenes que están en edad de trabajar (tasa del desempleo fue 13,8\%), las personas en situación de discapacidad, los desplazados, entre otros.

Las políticas públicas de empleo deben propender por dar mejores condiciones laborales, evitar a toda costa las intermediaciones laborales ilegales y generar oportunidades de trabajo, así como garantizar la sindicalización y los mecanismos de negociación colectiva. También es fundamental que las personas tengan acceso al sistema de seguridad social, entre otros derechos reglamentados en el país.

\subsubsection{Implementación de política pública}

Cuando se habla de implementación de políticas públicas se hace alusión a su puesta en marcha: es la toma de decisiones públicas para que se dé un proceso, se realicen o materialicen unos objetivos planteados en busca de soluciones a los problemas identificados por el propio gobierno o desde las comunidades. Es importante señalar que la implementación de una política pública se considera el proceso más difícil, debido a que de este punto depende 
fundamentalmente que el discurso se vuelva una realidad palpable y se materialice el objetivo deseado:

La implementación se vuelve entonces un proceso muy complejo y elusivo, también conflictivo, y es casi imposible encontrar una fórmula de coordinación que integre las diferencias y configure una acción colectiva armónica y efectiva. Los errores de diseño y los defectos de implementación son más comunes, obviamente, en las políticas sociales que enfrentan problemas cuyos componentes y factores explicativos arraigan en realidades vitales de difícil acceso e incidencia gubernamental. (Aguilar, 1993, p.16)

Para Aguilar (1993), esta práctica no resulta una fórmula perfecta por cuanto existen muchos ejemplos de políticas fracasadas; esto se debe a los errores de las grandes decisiones más que a los comportamientos de los operadores, es decir, de los funcionarios o instituciones que se encargan de hacer la puesta en marcha.

Por otro lado es importante tener en cuenta que toda política es una hipótesis que espera cumplir con objetivos mediante ciertas acciones y que en consecuencia es susceptible de error; igualmente se debe tener claro que los problemas públicos son escabrosos, de dificilísimo manejo, pluridimensionales y cambiantes, y que en su atención concurren numerosos actores con diversos intereses, puntos de vista y motivaciones; se impone encontrar fórmulas inteligentes de coordinación que integren la actividad de los diversos participantes sin perder de vista el objetivo a alcanzar.

Por estas razones es que el proceso de implementación de la política pública dejó de ser un proceso meramente administrativo y se convirtió en una etapa fundamental para el ciclo de la política pública. Así lo argumenta Ordoñez (2013, p. 211) quien explica que es el momento en donde hay un ejercicio de gobierno en el que la técnica, o lo administrativo, y la política interactúan, y en donde los 
caminos del diseñador y del implementador de la política confluyen. De esta manera la implementación se convierte en el resultado material de la acción del hacedor de la política pública, y es la correcta aplicación de este paso lo que determinará el éxito o fracaso de la misma.

Durante la fase de implementación, diversos factores influyen: el tamaño del grupo al que va dirigida la acción, el número de problemas que se pretenden resolver de ella, los agentes interesados y más. Entonces, la puesta en marcha de una política pública siempre va a estar expuesta a complicaciones y problemas. (Ordoñez, 2013, p. 211)

Es así como Ordóñez recomienda diseñar un plan de implementación, que no es otra cosa que una herramienta para realizar una prospectiva que permita anticiparse a los cambios o las dificultades y adaptar mejor el proceso a los entornos sociales y económicos que vayan resultando:

La capacidad para predecir los resultados esperados de la política es fundamental para el éxito de su análisis, así como una mejor formulación de la misma. A través de la predicción, se puede obtener una visión prospectiva, o de previsión, ampliando así las capacidades de comprensión, control y orientación de la sociedad". Con la simulación del futuro, teniendo en cuenta las variables que pueden afectar la política, se podrá hacer un plan de implementación más acertado. (Dunn, 2004, p. 128, citado por Ordoñez, 2013, p. 219)

Con esto se quiere decir que al tener un plan de implementación de la política pública se pueden disminuir los riesgos de fallar en las acciones. Además permite estar más alerta a los cambios y encontrar de forma acertada soluciones para avanzar en la consecución de los resultados que se esperan con la puesta en marcha de la política pública. Ordoñez (2013, p. 220) argumenta que con esto lo que se busca es "aprender haciendo, con la capacidad de adaptarse a los cambios que sobrevengan para que no deterioren el resultado de la política después de su puesta en marcha; en ocasiones el reto es minimizar al máximo los errores". 
Dentro del proceso de implementación existen tres modelos: uno denominado Top-Down (Roth, 2002) que trae consigo el clásico trabajo de la administración pública que se desarrolla de arriba hacia abajo, o del centro a la periferia; aquí prima la jerarquía y establece una diferencia entre la formulación, la toma de decisiones y la implementación. Otro que se conoce como Bottom-Up (Roth, 2002), contraria a la anterior, de abajo hacia arriba. Esta categoría es una alternativa que busca la eficiencia que no se reconoce en la descendente, puesto que al involucrar a los actores desde la base concilian las partes en pro de las soluciones. En el enfoque jerárquico la primacía de la ejecución radicará en los entes políticos o técnicos mientras que en la categoría Bottom-Up se posibilita la inserción de los actores sociales, quienes en un origen movilizaron la política pública; aquí se pretende partir del núcleo del problema para construir así la solución de manera paulatina.

Y un último enfoque llamado Mixed-Scanning, como lo señala Etzioni (1973) traduce "distintas formas de exploración", tiene en cuenta a los dos modelos ya mencionados pero va más allá, para incluir distintos tipos de análisis de acuerdo a las características del proceso de implementación que se estén observando. Este modelo se puede incluir dentro de una categoría de enfoques híbridos. Podría interpretarse también como un intento de encontrar un punto medio entre el enfoque arriba-abajo y el de abajo-arriba.

Para Ordoñez (2013, p. 215) es interesante saber que mientras el Top-Down constituye la forma de implementación más básica y utilizada en los países en vía de desarrollo, con una puesta en marcha de las decisiones desde el centro hacia la periferia y poca interacción entre la administración y la sociedad, el modelo Bottom-Up predomina en los países desarrollados, en el que se tiene mayor conciencia de la importancia de hacer un plan de implementación paso a paso, flexible a los posibles cambios que pueda enfrentar y en donde la 
ciudadanía juega un rol fundamental en un proceso que empieza desde el momento del diseño de la política y en donde el Estado no es percibido como un tercero sino que la sociedad se siente parte de él.

\subsubsection{Territorialización de la política pública}

El territorio, según la Real Academia Española (2014), es "porción de la superficie terrestre perteneciente a una nación, región, provincia".

Este es un concepto polisémico que tiene, de acuerdo con la disciplina de estudio, su propio enfoque. Tener claro este término es fundamental (Monnet, 1999 p.1) "en la medida que se trata de entender el territorio como un producto, como un espacio producido en ciertas condiciones, para ciertos fines, por ciertos actores". Por esta razón es preciso examinar algunos de los distintos modos de producción del territorio, o sea la territorialización, en cuyo concepto, según este autor, no hay consenso.

La territorialización es el proceso de identificación, definición y producción de un espacio como territorio por un actor geográfico (individual o colectivo). Quien además, examina los distintos modos de producción del territorio, o sea territorialización, del cual propone clasificar como "areolar" (constituyendo áreas) y "reticular" (constituyendo redes). (Monnet, 1999 p. 2)

Otra definición del término es la que presenta Barañano (2005. p. 342): "la territorialización es la estrategia que se utiliza, y el efecto que causa delimitar un territorio - o espacio - [...] La territorialización sugiere un control determinado por una persona, grupo social o étnico", quien es citado por Palomares (2015) para entender el proceso como "un concepto inmaterial, que aun cuando tiene que ver con los límites y control de un espacio, ésta sólo se presenta en el 
reconocimiento de los habitantes, pudiendo ser de carácter colectivo o individual y subjetivo".

Sobre este concepto Jolly (2012) argumenta que no hay una teorización concreta porque el término es menos utilizado. Sin embargo, presenta una cita de Vannier utilizada por Monnet: el término de territorialización "insiste en la acción humana que se fundamenta en un sistema de valor para producir un territorio". En breve, Jolly expone lo que para Monnet significa territorio, territorialidad y territorialización:

Considerando al territorio a la vez como concepto y como producción social del espacio y partiendo de una definición del territorio como "el espacio material donde se realiza una acción humana repetitiva", mientras la territorialidad corresponde a "los valores atribuidos a un territorio" y la territorialización a las "acciones que se hacen sobre el espacio material fundamentadas en una territorialidad". (Jolly, 2012 p. 7. El resaltado no es del original)

Con cada uno de los conceptos anteriores el autor busca realizar una reflexión y encontrar el núcleo central de su discusión, que gira en torno al "sistema socio territorial" como factor determinante y denominador común entre los tres significados.

Se entiende entonces la territorialización de la política pública como el acto de adaptar a un territorio y a su realidad local una iniciativa, estrategia o solución aportada por el gobierno o las comunidades. En otras palabras, una política pública "territorializada" es una política singular que toma en cuenta especificidades locales para lograr resultados más acertados.

En el contexto de las políticas públicas el territorio es sujeto de construcción socio-político, por tanto, ámbito de ejecución del poder. En su acepción de espacio físico ocupado por una población es potencial para el desarrollo de 
capacidades y sinergias, para transformar recursos tangibles e intangibles en atributos para mejorar la calidad de vida. La apuesta es que desde la construcción de las políticas públicas y en cada uno de sus pasos sea territorializada para adaptarla a la situación y problemática de los habitantes que están inmersos en el territorio.

\subsection{Trabajo y Empleo: una breve conceptualización según la OIT y el contexto colombiano.}

Un punto de partida para este apartado es definir el significado de empleo o trabajo, es decir, tratar de entender las palabras que se utilizan para describir lo que hacen las personas para ganarse la vida. Los distintos significados apuntan a los diferentes aspectos del empleo que valoran las personas, y las opiniones sobre lo que es un empleo influirán de manera casi inevitable en la forma que adopten las políticas laborales.

Para los estadísticos un empleo es "un conjunto de tareas y funciones que desempeña, o debería desempeñar, una persona, ya sea para un empleador o por cuenta propia". Sin embargo, esta definición estadística no nos dice nada acerca de lo que no debe considerarse un empleo.

Las normas internacionales consideran que los derechos humanos básicos marcan los límites de lo que es inaceptable. Entre ellas cabe mencionar la Declaración Universal de Derechos Humanos de las Naciones Unidas (1948) y la Declaración relativa a los Principios y Derechos Fundamentales en el Trabajo (1998) de la OIT, que especifica normas laborales básicas. Si se combinan esas perspectivas diferentes, el empleo se define como "una actividad que genera ingresos, monetarios o en especie, sin infringir los derechos humanos". 
De acuerdo al planteamiento del Programa de las Naciones Unidas para el Desarrollo (PNUD) desde la perspectiva de desarrollo humano, el concepto realmente relevante es el trabajo, no el empleo. Según el PNUD "el empleo, un concepto limitado que viene definido por un conjunto de tareas o actividades predeterminadas asignadas a plazos concretos, se sitúa en un marco de insumos-resultados donde el trabajo es el insumo y el producto o servicio su resultado" (2015). Para esta organización el concepto empleo no abarca el trabajo creativo (por ejemplo, la obra de un escritor o pintor); el empleo no abarca tampoco el trabajo no remunerado de cuidar a otras personas, ni tampoco incluye el voluntariado. Así, "el trabajo es un concepto más amplio, que abarca el ámbito laboral, pero que también va más allá mediante la inclusión de las dimensiones mencionadas arriba, que tradicionalmente no entran el marco del empleo, pero que son fundamentales para el desarrollo humano" (2015).

Para el PNUD (2015),

...el trabajo es el medio para dar rienda suelta al potencial humano, a la creatividad, a la innovación y a la imaginación. Es esencial para que la vida humana sea productiva, útil y significativa. Permite a las personas ganarse la vida, es un canal de participación en la sociedad, proporciona seguridad y confiere un sentido de dignidad. El trabajo esta inherentemente e intrínsecamente ligado al desarrollo humano.

Sobre el empleo dice el PNUD que:

...proporciona ingresos y apoya la dignidad humana, la participación y la seguridad económica. Sin embargo, en el marco del empleo no se incluyen muchos tipos de trabajo que tienen importantes implicaciones para el desarrollo humano, como el trabajo de cuidados, el trabajo voluntario y el trabajo creativo (por ejemplo, la escritura o la pintura). (2015, p.3) 


\subsubsection{Conceptualización según la OIT sobre trabajo y empleo}

Según Neffa (2014, pp. 10-11) el trabajo es una actividad realizada por las personas orientada hacia una finalidad, la producción de un bien, o la prestación de un servicio, que da lugar a una realidad objetiva, exterior e independiente del sujeto, y socialmente útil para la satisfacción de una necesidad. Ahora bien, cuando el trabajo así definido se hace para obtener a cambio un ingreso, en calidad de asalariado, de empleador, o actuando por cuenta propia, estamos en presencia del empleo.

Por otra parte, según Neffa (2014), la OIT considerará con empleo "a todas las personas que tengan más de una cierta edad especificada y que durante un breve periodo de referencia, tal como una semana o un día, estuvieran en cualquiera de las siguientes categorías: con un empleo asalariado o con un empleo independiente (OIT, 1988)". Las recomendaciones de la OIT se enuncian así:

Personas con empleo asalariado:

a. trabajando durante el período de referencia por un sueldo o salario en metálico o en especie;

b. con empleo, pero sin trabajar durante el periodo de referencia y que mantienen un vínculo formal con su empleo, según los siguientes criterios: pago ininterrumpido de sueldos o salarios; garantía de reintegración en el empleo al término de la contingencia o un acuerdo respecto de la fecha de reintegración y durante la ausencia del trabajo, un periodo en el cual los trabajadores pueden percibir una remuneración social sin obligación de aceptar otros trabajos.

c. las personas ausentes de su trabajo temporalmente (por causa de enfermedad o accidente, días festivos o vacaciones, huelga, paro de empleadores, licencia de estudios o de formación profesional, licencia por maternidad o paternidad, suspensión por coyuntura económica difícil, desorganización o suspensión temporal del trabajo por razones tales como el mal tiempo, averías mecánicas o eléctricas, escasez de 
materias primas o combustibles), pero siempre que tuvieran un vínculo formal con su empleo;

d. los aprendices que hayan recibido una retribución en metálico o en especie, pueden clasificarse como "trabajando" o "con empleo pero sin trabajar", al igual que las demás personas con empleo asalariado;

e. los miembros de las fuerzas armadas, incluyendo a los miembros permanentes y temporales.

Personas con empleo independiente:

a. "trabajando" durante el periodo de referencia, y realizando algún trabajo (o sea una hora de trabajo por lo menos) para obtener beneficios o ganancia familiar, en metálico o en especie;

b. "con una empresa pero sin trabajar", porque están temporariamente ausentes del trabajo durante el periodo de referencia por cualquier razón específica;

c. Ios trabajadores familiares no remunerados que están trabajando al menos 15 horas durante el periodo de referencia;

d. las personas ocupadas en la producción de bienes y servicios económicos, para consumo propio o del hogar, si dicha producción constituye una aportación importante al consumo total del hogar;

e. los empleadores, trabajadores por cuenta propia y miembros de cooperativas de producción también pueden clasificarse como trabajando o con empleo pero sin trabajar. (Neffa, 2014, pp. 15-17)

Finalmente, Neffa (2014, p. 17) en las recomendaciones internacionales de actualidad en estadísticas del trabajo (edición 2000) dice:

...debería considerarse como personas con empleo independiente a los trabajadores familiares no remunerados que estén trabajando sin consideración al número de horas trabajadas durante el período de referencia. Los países que, por razones particulares, prefieren introducir un criterio de tiempo mínimo de trabajo como condición para incluir a los trabajadores familiares no remunerados entre las personas con empleo, deberían identificar y clasificar aparte a los que trabajan menos del tiempo prescripto.

En este punto es preciso rememorar que en las sociedades antiguas tuvo origen una de las primeras concepciones, la clásica, en la cual el trabajo era concebido como tortura, tripalium, lo cual no valorizaba ni a la tarea ni al individuo. 
Contrario a esa antigua forma de entender el trabajo, en la sociedad capitalista contemporánea el trabajo está predominantemente asociado a valores positivos en la vida cotidiana, en razón de la valorización de la ética del trabajo influenciada por la doctrina protestante, conforme a lo argumentado por Weber (Blanch Ribas, 2003; Borges \& Yamamoto, 2004).

Con el capitalismo, el trabajo se asoció al sustento material y, en relación con el empleo, se caracterizó por relaciones contractuales asalariadas. Mientras el trabajo remite a la transformación de la naturaleza, el empleo está asociado, con mayor frecuencia, a relaciones contractuales, al vínculo formal con la organización, a las obligaciones y al salario. (Borges \& Yamamoto, 2004)

Es claro, que con el transcurrir de los años el trabajo ha tenido importantes cambios, para Kovács (2005) estos se pueden distinguir especialmente en las sociedades capitalistas y se identifican por tener formas flexibles de empleo que emergen a partir de las últimas décadas del siglo $\mathrm{XX}$ como son: el trabajo temporal, de tiempo parcial, a domicilio y autoempleo; -en Colombia las OPS u orden de prestación de servicios-. Esto para el autor se da como parte de la crisis del modelo de empleo predominante en los países de capitalismo avanzado. Sin embargo, para Pulido-Martínez (2007, p.29) estos nuevos cambios generan especialmente en los países mal llamados de la periferia "la destrucción violenta de la maneras tradicionales de vivir y pensar que constituyen las bases de la identidad".

Lo anterior contrasta con el planteamiento De la Garza Toledo (2001, pp. 11 12), quien afirma que el debate teórico sobre la crisis del trabajo puede asumir varias formas, pero esa declinación del trabajo es sobre todo por la marginación de los trabajadores y sus organizaciones; es una crisis de deslegitimación. Su pérdida de centralidad no la ha substituido la simple fragmentación posmoderna sino otra centralidad: la del capital y la del empresario como sujeto (p. 26). 
Por su lado, el empleo configura una forma de trabajo asalariado, tradicionalmente característica del capitalismo, lo que ha generado una equiparación equivocada de los significados relativos a los dos conceptos. Frente la variedad de formas de empleo vigentes en la actualidad, se suman la diversidad, la heterogeneidad y la complejidad de la clase trabajadora, incluyendo a "(...) todos aquellos y aquellas que venden su fuerza de trabajo a cambio de salario (...)". (Antunes, 2000, p. 103)

Con lo anterior, es clara la existencia de diferencias entre empleo y trabajo; además su comprensión está sujeta a los momentos históricos, filosóficos e ideológicos por los que atraviesa la construcción del término.

\subsubsection{El trabajo/empleo en el contexto colombiano}

Para el contexto colombiano, el trabajo/empleo está protegido como derecho en el Artículo 25 de la Constitución Política de Colombia 1991: "el trabajo es un derecho y una obligación social y goza, en todas sus modalidades, de la especial protección del Estado. Toda persona tiene derecho a un trabajo en condiciones dignas y justas" (CPC, 1991 p. 5). Existe toda una protección jurídica y normativa para defenderlo como derecho, sin que se goce de manera efectiva por la población que está en edad de trabajar y tener un empleo en el país.

Así se evidencia en las cifras reportadas por el DANE en abril de 2014 cuando más del $9 \%$ de la población en esos momentos estaba desocupada, es decir más de 2,46 millones de colombianos, como se presenta en la siguiente gráfica: 
Gráfica 1: Tasa desempleo en Colombia, Abril 2014 (Dane)

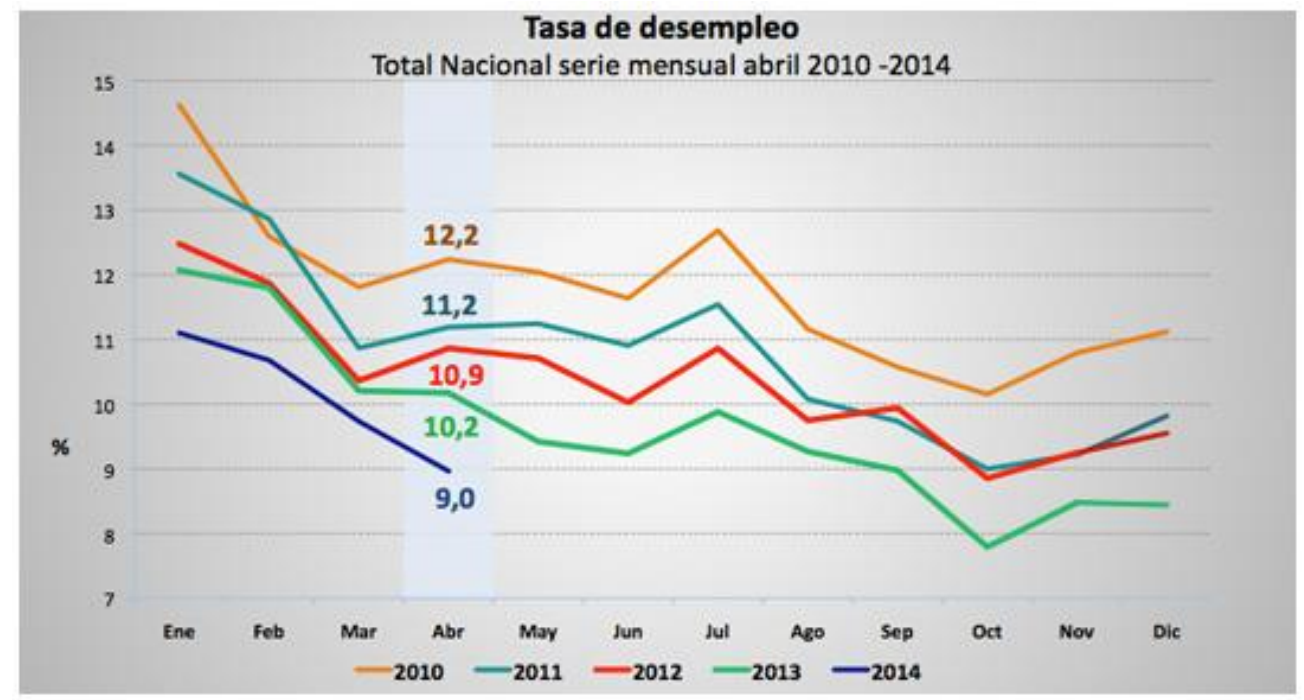

Pese a las estrategias implementadas por los gobiernos de turno para la generación de empleo, aunque las cifras de desempleo han ido a la baja en los últimos años, las oportunidades de empleo para los colombianos siguen siendo reducidas. Esto ha obligado a los gobiernos locales a formular políticas públicas territorializadas para tratar de dar solución de esa problemática social, que trae consigo consecuencias significativas para el desarrollo de los territorios y de sus pobladores. En ese sentido y haciendo alusión a la descentralización que rige a Colombia, y de acuerdo a la Ley 715 de 2001 en el marco de sus competencias reguladas en materia de empleo, el gobierno de Barrancabermeja formula el Acuerdo 005 de 2008 atendiendo a la garantía de este derecho fundamental, procurando dar respuesta a una necesidad de la comunidad: la generación de oportunidades laborales dentro de su territorio para aportar al desarrollo local. 


\subsection{Definiciones: Mano de obra calificada y no calificada}

Según la Clasificación Nacional Ocupaciones en su versión 2007, documento elaborado por el Observatorio Laboral y Ocupacional colombiano, de la Dirección de Empleo y del Trabajo del SENA, se define:

Definición Mano de Obra Calificada (MOC): son los trabajadores cuyo conocimiento sobre una actividad o profesión puede ser demostrable mediante certificación o diploma acreditado por una institución de educación superior formal o instituto tecnológico, además de la experiencia específica certificada. Por ejemplo: topógrafos, electricistas, mecánicos, técnicos, tecnólogos o profesionales en cualquier área de la ingeniería, salud, ciencias contables, ciencias sociales, entre otros.

Definición Mano de Obra No Calificada (MON): aquellos trabajos donde se ejecutan actividades complementarias y de apoyo, las cuales se caracterizan por el predominio de actividades manuales o tareas de simple ejecución, sin que se requiera para ello educación técnica profesional, tecnológica y/o profesional. Por ejemplo: obreros, ayudantes, aseadoras y oficios varios.

\subsection{El Desarrollo y la dimensión del desarrollo local: implicaciones en materia de empleo, aproximaciones para su definición}

3.4.1. ¿Qué se entiende por Desarrollo?

Sobre desarrollo es mucho lo conceptualizado desde diversas corrientes y enfoques de estudio. Sin embargo, comúnmente se le asocia con adjetivos como 
crecimiento, modernidad, civilización, riqueza, evolución, adelanto, progreso, avance, mejora, entre otros.

Para explicar el desarrollo es preciso entender que existen diversas discusiones teóricas, cada una en su línea del tiempo, con una posición que puede ser ideológica, económica, filosófica, institucional o social; de acuerdo a esto se va orientando la dimensión que varía el significado del término y adquiere otras comprensiones ${ }^{2}$.

Para este trabajo de investigación se adoptará el concepto de desarrollo brindado por el economista indio Amartya Sen (1999), quien tiene un punto de vista no tradicional. El autor plantea que para hablar del desarrollo de una sociedad hay que analizar la vida de quienes la integran, que no puede considerarse que haya éxito económico sin tener en cuenta la vida de los individuos que conforman la comunidad. El desarrollo es entonces el desarrollo de las personas de la sociedad. Por este motivo define concretamente: "el desarrollo es un proceso de expansión de las capacidades de que disfrutan los individuos" (Sen, 1999, citado por London, 2006, p.19).

Aunque al autor no le parece atractiva la palabra capacidad en sí misma (Sen, 2001), explica que se ha usado para hablar de las tierras y no de las personas. Particularmente, él elige utilizarla porque con ella se expresan las combinaciones alternativas de lo que una persona puede lograr hacer o ser: las capacidades simbolizarían las posibilidades que tienen los individuos de alcanzar desempeños valiosos.

2 Existen quienes definen al desarrollo relacionándolo íntimamente con el crecimiento del producto per cápita, como por ejemplo los autores clásicos y muchos de los que estuvieron luego de ellos hasta los años inmediatamente posteriores a la segunda posguerra, como por ejemplo Lewis (1954), Rostow (1956) y Myrdal (1957). También están quienes lo definen de manera más amplia y no limitándose al concepto de crecimiento, autores tales como Schumpeter (1967), Mynt (1954), Olivera (1959) y Sen (1999), entre tantos otros. 
Para Sen (1999) el desarrollo es un proceso de expansión de libertades reales de las que disfruta el individuo. El autor define que existen cinco tipos de libertades muy importantes que se deben identificar: las libertades políticas, los servicios económicos, las oportunidades sociales, las garantías de transparencia y de seguridad protectora. Estas cinco libertades deberían estar cubiertas para el total de la población.

Al respecto, sobre la libertad de servicios económicos y oportunidades sociales propuesta por el autor, es indispensable que se generen opciones para que las personas tengan acceso al trabajo; eso permitirá la generación de ingresos a los individuos para satisfacer otras necesidades para su propio desarrollo. Con esta idea, Sen (1997) señala que la pobreza y el desempleo coartan la forma en que los individuos pueden disfrutar y apreciar; representan pues severas violaciones a la libertad.

En este sentido el desarrollo debería generar aportes para acabar con flagelos tales como la pobreza, la tiranía, la escasez de oportunidades económicas y las privaciones sociales sistemáticas, entre otras, porque privan al hombre de su libertad. La falta de libertades fundamentales posee una estrecha relación con la pobreza, debido a que ésta coarta la libertad de los individuos para satisfacer las necesidades básicas que le concedan la posibilidad de vivir dignamente: obtener un nivel de nutrición suficiente, acceder a servicios de salud y educación o poseer una vestimenta y vivienda aceptables.

Esta visión del desarrollo propone un gran reto, que invita a repensarlo desde otras lógicas; involucra a los estamentos gubernamentales y a las comunidades para su planteamiento, sustentación, viabilización y puesta en marcha. El 
desarrollo está imbuido en los pueblos, en la gente, en sus territorios, en los recursos, incluso con su mano de obra, su técnica, su innovación.

El reto es identificarlos para potencializar su propio desarrollo, aquel que los lleve no sólo a la satisfacción de sus necesidades básicas si no a la consecución de su libertad, de su crecimiento como ser y de sus posibilidades de ser.

\subsubsection{El Desarrollo Local}

Para abordar el concepto del desarrollo local es preciso reconocer que éste hace parte de los distintos y variados enfoques que los teóricos han producido del polisémico término desarrollo. Su surgimiento se da luego de que diversas teorías, entre el ensayo y el error, intentaran dar respuesta a los problemas de la sociedad, y que en un principio pretendieran con el sólo desarrollo, mediante la ayuda que el centro le brindaría a la periferia con el crecimiento económico a través de la globalización de los mercados y un sinfín de acciones, sacar del atraso a los países que venían rezagados. Al contrario, el resultado de estas macro políticas iniciales evidenció que esto ha diezmado la participación de los países "sub-desarrollados" en la economía mundial, como lo plantea García (2004) referido del estudio de Die Gruppe von Lissabon sobre los límites de la competencia, citado por Sonntag y Arenas que se expone a continuación:

...en 1980, la participación de los 102 países más pobres en el intercambio de mercancías representaba $7,9 \%$ de las exportaciones y $9 \%$ de las importaciones a nivel mundial; solamente 10 años más tarde, estas tasas se redujeron a $1.4 \%$ y $4.9 \%$, respectivamente, en el comercio intercontinental, la participación de África y el Medio Oriente bajó de $14,1 \%$ en 1970 a 9,9\% en $1990 \%$, la de América Latina de $7,8 \%$ a $6,1 \%$ y la del ex bloque Soviético de $7,3 \%$ a $4,1 \%$; al extrapolar estos datos para los próximos 20 años, la participación de África, del Medio Oriente, de América Latina, Rusia y Europa Oriental bajaría de $39,2 \%$ (1970) a 5\% en el 2020. (García, 2004, p.140) 
Para García estas situaciones desiguales, dispares y contradictorias a un desarrollo posible para todos son, en rasgos generales, las que permiten una concepción fundamentada para generar una nueva estrategia, porque no es fácil aplicar la misma a cada país, como si fueran homogéneos,

...pues cada uno posee realidades socioeconómicas, institucionales, políticas, culturales y ambientales propias, lo cual exige, la elaboración de una agenda de desarrollo adaptada a las condiciones locales donde se expongan las fortalezas, oportunidades y debilidades que se presentan para emprender el proceso y las políticas concretas que permitirán alcanzar la sustentabilidad en materia económica, social y ambiental. (García, 2004. p. 144).

Con el paso del tiempo el desarrollo local ha tomado preponderancia como estrategia de desarrollo para que las comunidades emprendan sus propios modelos -adaptados a las circunstancias culturales, políticas, administrativas, sociales y económicas- con los que se impulse la calidad de vida, haciendo uso sostenible de los recursos del territorio, para competir en los mercados globales y generar riquezas para su entorno local. Algunas definiciones sobre desarrollo local permiten entender más el concepto:

Alburquerque plantea al desarrollo local como "un proceso de transformación de la economía y la sociedad locales, orientado a superar las dificultades y retos existentes, que busca mejorar las condiciones de vida de su población, mediante la actuación decidida y concertada entre los diferentes agentes socioeconómicos locales (públicos y privados), para el aprovechamiento más eficiente y sustentable de los recursos endógenos existentes, mediante el fomento de las capacidades de emprendimiento empresarial locales y la creación de un entorno innovador en el territorio". (Citado por García, 2004, p. 146)

Es así como el proceso de desarrollo recibe una visión resultante del esfuerzo organizativo e innovador del conjunto de la sociedad y no solamente del correcto desempeño de los mercados, focalizada en la estrategia local que busca 
promover la dinamización empresarial, el estímulo a las innovaciones, la generación de externalidades derivadas de la asociatividad, la proximidad y la utilización más eficaz posible de todo el potencial de desarrollo disponible o incorporable al territorio (Alburquerque, 2002). También destaca el proceso en este tipo de desarrollo:

Un proceso en el cual los actores e instituciones locales se movilizan para apoyar las diferentes acciones, tratando de crear, reforzar y preservar actividades y empleos, utilizando los medios y recursos del territorio. Además, las iniciativas se orientan a mejorar las condiciones del entorno local, tratando de construir un ambiente territorial favorable a la actividad empresarial innovadora. El énfasis se pone en los aspectos cualitativos y extraeconómicos, los cuales son integrados como factores aglutinantes y facilitadores del desarrollo, en su capacidad para buscar soluciones, mediante un mejor aprovechamiento de los recursos endógenos existentes y la vinculación en red de los diferentes actores socioeconómicos locales (Albuquerque, 2004, p.157-171).

Por otra parte, según Garofoli (1994) "el desarrollo económico se convierte en local, cuando el impacto del proceso de transformación sobre la comunidad local asume características bien definidas". También sustenta que el desarrollo local "es un proceso de crecimiento económico y cambio estructural que conduce a una mejora del nivel de vida de la población local".

Boisier (1999, p.10) expone cómo ha sido la evolución y marco teórico del desarrollo local. Algunos de sus argumentos los define a través de importantes exponentes de este concepto. Uno de éstos es la idea elaborada por la OCDE (1995, p.21):

El enfoque local del desarrollo es una respuesta a los problemas del desempleo y desorganización económica causados por la decadencia industrial y las deslocalizaciones. Después del fracaso relativo de los proyectos organizados y aplicados por organismos públicos 
nacionales, la idea de utilizar procedimientos locales ha ido ganando vigencia. (Citada por Cuervo, L.1999, p.12)

Vázquez-Barquero (1988, p.129) define el desarrollo local como:

Un proceso de crecimiento económico y de cambio estructural que conduce a una mejora en el nivel de vida de la población local, en el que se pueden identificar tres dimensiones: una económica, en la que los empresarios locales usan su capacidad para organizar los factores productivos locales con niveles de productividad suficientes para ser competitivos en los mercados; otra, sociocultural, en que los valores y las instituciones sirven de base al proceso de desarrollo; $y$, finalmente, una dimensión político-administrativa en que las políticas territoriales permiten crear un entorno económico local favorable, protegerlo de interferencias externas e impulsar el desarrollo local.

El desarrollo local puede ser entendido como un modelo orientado a la acción para impulsar un territorio determinado, en donde los actores sociales e institucionales trabajan mancomunadamente por brindar condiciones que permitan la generación de capacidades sociales, económicas, culturales, políticas y ambientales para mejorar principalmente el tejido social, la organización de las comunidades, resolver los retos que enfrentan, aumentar las cadenas de producción y gestionar sus propios recursos de manera sustentable.

Con lo anterior, se destaca como lo señala García (2004 p.150) la necesidad de instrumentar políticas públicas adecuadas a las características territoriales concretas, orientadas a motorizar las fortalezas y atenuar las debilidades que presenta el territorio. Para esto es vital la participación activa de los diferentes actores sociales locales -público/privados- en el diseño y aplicación de las políticas de desarrollo con el fin de movilizar y utilizar de manera eficiente las potencialidades que se tengan desde lo local, porque son ellos los protagonistas de principio a fin en la consecución de su propio desarrollo. 


\subsubsection{El Desarrollo para el empleo}

Realizar una aproximación a la definición de este desafío que se asigna al desarrollo en la generación de oportunidades laborales dignas y decentes para las personas es una apuesta interesante. Al respecto se cita la siguiente frase de la OIT propuesta para la Agenda de Desarrollo Post 2015: "el desarrollo viene con el empleo". Para la OIT (2013a) "el trabajo permite a los hogares de bajos recursos superar la pobreza, y que la expansión del empleo productivo y decente es la vía hacia el crecimiento y la diversificación de las economías".

Con esta afirmación la OIT hace un llamado a todos los países para que sin importar el nivel de desarrollo, adopten como consigna impulsar el empleo para generar en las comunidades prosperidad, inclusión y cohesión social de manera sostenible y creciente. De lo contrario, la falta de empleos y oportunidades para la vida generará pobreza en los hogares, menos crecimiento, menos seguridad, menos desarrollo humano y económico:

Los empleos vinculan a las personas con la sociedad y la economía en las que viven. El acceso a un trabajo seguro, productivo y remunerado de manera justa - asalariado o por cuenta propia - es un factor fundamental para la autoestima de las personas y las familias, que les afirma su sentimiento de pertenencia a una comunidad, y les permite hacer una contribución productiva. El cambio hacia un desarrollo incluyente y sostenible no será posible si se niega a millones de personas la oportunidad de ganarse la vida en condiciones dignas y equitativas. (OIT, 2013, p.1)

Con esta premisa la organización busca incluir dentro de la agenda de desarrollo, luego de los objetivos del milenio 2015, que las Naciones Unidas y la comunidad internacional reconozcan como prioridad la creación de empleos como eje para dinamizar el desarrollo de los países. Éste es el tema propuesto para las discusiones que se generen en los próximos decenios. 
Para esto la OIT plantea que los gobiernos centren su trabajo en la creación de políticas públicas en las que prime la protección social, la diversificación de las economías, las instituciones gubernamentales estables y sólidas, respetuosas del Estado de derecho, se integre a los trabajadores en un sistema formal de prestaciones e impuestos, entre otros, para que se generen nuevos empleos e ingresos que allanen el camino hacia un desarrollo más incluyente, equitativo y sostenible que, apoyado en el trabajo, beneficie especialmente a los sectores más vulnerables:

El desarrollo sostenible no es posible sin lograr avances en materia de empleo y en el programa de trabajo decente. El crecimiento económico no será sostenible si se basa en condiciones de trabajo pobres e inseguras, salarios reprimidos, en un aumento en el número de los trabajadores pobres, y en un incremento de las desigualdades. Por el contrario, el proceso de desarrollo se verá favorecido a través de la puesta en marcha de políticas e instituciones que ayuden a crear más y mejores empleos. Además de su efecto en el crecimiento económico, el empleo, los derechos, la protección social y el diálogo son elementos integrales del desarrollo. (OIT, 2015, p.8)

Igualmente el Banco Mundial (2013, p.13) asegura que "el empleo es la piedra angular del desarrollo económico y social”. Le da un valor importante al empleo como eje dinamizador del desarrollo porque ofrece los medios de subsistencia para que las personas escapen de la pobreza e incrementen su nivel de vida, aumenta el crecimiento económico del país, permite que prosperen las sociedades, logra transformar a las personas que tienen oportunidades laborales porque les da felicidad y autoestima; también considera que puede contribuir a la cohesión social, promueve el intercambios de ideas, nuevos conocimientos e incluso al restablecimiento de la paz.

El empleo genera aumento de los ingresos y mayores beneficios a medida que los países crecen, pero también impulsa el desarrollo. La pobreza cae a medida que las personas logran escapar de las penurias a través del trabajo y a medida que los empleos que permiten 
el empoderamiento de las mujeres conducen a un incremento de la inversión en los niños. (...) Las sociedades florecen a medida que los empleos congregan a personas de distintos orígenes étnicos y sociales y ofrecen alternativas al conflicto. El empleo es, en consecuencia, más que un efecto derivado del crecimiento económico. Es un elemento transformador: es lo que ganamos, lo que hacemos e incluso lo que somos. (Banco Mundial, 2013, p. 64)

El Banco Mundial (2013, p.14), también explica que hay empleos que tienen mayor valor para la sociedad que para las personas; algunos empleos pueden tener efectos negativos que no van en concordancia con lo que pretende el desarrollo planteado hasta el momento, ese que es distinto al crecimiento y la acumulación del capital -ese que busca principalmente la libertad del ser mediante la potenciación de las capacidades-. Específicamente dice que "aquellos empleos que son perjudiciales para el medio ambiente generan un alto costo que todos deben pagar. Es así, como algunos tipos de empleo son más beneficiosos para el desarrollo, mientras que otros tienen pocos efectos en él, aunque sean atractivos para las personas". Esta mención es importante porque más adelante se explicará cómo las economías extractivas, entre estas la del petróleo, son nocivas especialmente para los ecosistemas -así sean de provecho para unas cuantas personas que se beneficien con su extracción y su trabajo olvidando el impacto que esto causa a la naturaleza-.

Pasando al contexto latinoamericano, de acuerdo a la Comisión Económica para América Latina y el Caribe (CEPAL) (2012), ningún país de América Latina y el Caribe ha logrado en el largo plazo la combinación virtuosa entre un elevado crecimiento del empleo y de la productividad, condición necesaria para superar la pobreza y la desigualdad. Por esta razón propone que los países latinos y del caribe vayan en la siguiente dirección hacia el desarrollo: generar un cambio estructural que permita avanzar hacia sectores más intensivos en conocimiento, 
dinamizar la convergencia para reducir las brechas internas y externas de ingresos y productividad, y por último igualdad de derechos.

Bajo esos tres grandes desafíos la CEPAL considera que las políticas deben estar orientadas a lograr un crecimiento sostenido a tasas elevadas, suficientes para cerrar brechas estructurales y generar empleos de calidad; cambiar los patrones de consumo y producción en el contexto de una verdadera revolución tecnológica con sostenibilidad ambiental y garantizar la igualdad sobre la base de una estructura productiva más convergente, con protección social universal y construcción de capacidades.

Con estas condiciones, los entes gubernamentales de Colombia deberán hacer grandes reformas para crear empleos dignos y decentes, que mejoren las condiciones de los trabajadores, en donde se garanticen su protección social, la equidad y acceso para jóvenes, mujeres y personas en condición de discapacidad, afrodescendientes e indígenas -entre otras comunidades que reclaman espacios laborales-. Para esto es necesario que en el país se impulse la cualificación de la mano de obra para activar otros sectores económicos menos intensivos y agresivos con los recursos naturales pero igual de necesarios y más sostenibles en el tiempo y con las generaciones futuras; erradicar los empleos informales y el subempleo que generan precariedad en las condiciones de los trabajadores; mejorar las condiciones de contratación para generar más estabilidad laboral. Se requiere con urgencia una ética del trabajo para asegurar una justicia social que ayude a dinamizar el desarrollo, ese que demandan las comunidades de la mano de un Estado más activo y gestionador de políticas públicas responsables a las necesidades e intereses de sus gentes. 


\subsection{Economías Extractivas: en el sector petróleo}

Gudynas (2013) ofrece una definición al concepto economías extractivas. Inicialmente presenta los antecedentes que están ligados con dos tipos de actividades, la explotación minera y petrolera, y un destino específico, su exportación. Además, reconoce que usualmente se referencia como una industria (industrias extractivas). Sin embargo, esto queda despejado en la redefinición que hace al concepto en su teoría.

Para el autor, referirse al extractivismo corresponde a un tipo de extracción de los recursos naturales y el impacto que se hace sobre el ambiente. Esta es una condición principal para definirlo. Aquí se deben considerar tres dimensiones básicas para diferenciar las modalidades que se presentan cuando ocurre extractivismo en los recursos naturales: en primer lugar se da por el volumen de recursos extraídos, segundo en la extracción y por último el destino de los recursos. Otro aspecto importante es considerar la intensidad bajo la cual se realiza la extracción, ya que puede haber extracciones de volúmenes pequeños o medios pero que tienen un grave impacto para el entorno. Los destinos de los recursos extraídos deben ser igualmente precisados.

Gudynas (2013, p. 3), define el extractivismo como "un tipo de extracción de recursos naturales, en gran medida con un volumen o alta intensidad, y que están orientados esencialmente a ser exportados como materias primas sin procesar, o con un procesamiento mínimo". Señala que las etapas del extractivismo van desde las acciones de exploración, descubrimiento, etc. -las actividades propias de la extracción- pero también las fases posteriores (como cierre y abandono de los sitios apropiados). Lo anterior, se presenta porque existen otros tipos de extracciones de los recursos naturales, pero que se destinan para el consumo 
humano y otras actividades que no impactan tan gravemente el ambiente. La diferenciación que realiza Gudynas está planteada en la siguiente tabla, en la que muestra los tipos de extracción y el destino de los recursos naturales frente a cada caso, utilizando ejemplos explicativos para entender su postura al respecto:

Tabla 1: Tipos de extracción y destino de recursos naturales

\begin{tabular}{|c|c|c|c|}
\hline \multirow{2}{*}{$\begin{array}{c}\text { Destino } \\
\text { Comercial }\end{array}$} & \multicolumn{3}{|c|}{ Volumen / Intensidad de la extracción } \\
\hline & Bajo & Medio & Alto \\
\hline Local & $\begin{array}{l}\text { Cultivo campesino } \\
\text { de alimentos para } \\
\text { autoconsumo }\end{array}$ & $\begin{array}{c}\text { Tala de bosque } \\
\text { nativo para obtener } \\
\text { leña }\end{array}$ & $\begin{array}{l}\text { Captura de agua para } \\
\text { riego o uso doméstico }\end{array}$ \\
\hline Nacional & $\begin{array}{c}\text { Fibras vegetales } \\
\text { para cestería, } \\
\text { techos, etc. }\end{array}$ & $\begin{array}{c}\text { Frutas y verduras } \\
\text { convencionales para } \\
\text { mercados nacionales }\end{array}$ & $\begin{array}{c}\text { Arenas y gravas para } \\
\text { construcción }\end{array}$ \\
\hline Exportación & Alimentos orgánicos & $\begin{array}{c}\text { Flores de } \\
\text { invernadero }\end{array}$ & $\begin{array}{c}\text { EXTRACTIVISMO } \\
\text { Minerales } \\
\text { Hidrocarburos } \\
\text { Monocultivos de } \\
\text { exportación }\end{array}$ \\
\hline
\end{tabular}

Fuente: Gudynas (2013, p.3).

La definición que el autor presenta articula dos miradas que se relacionan: una mirada local porque se enfoca a la actividad de extraer los recursos naturales que ocurre en territorios específicos, con sus comunidades afectadas y ecosistemas alterados. Por el otro, contiene una dimensión global ya que reconoce que esa apropiación tiene un destino que se orienta al comercio exterior.

Otro aspecto fundamental del planteamiento que hace Gudynas al respecto, es el énfasis local que tiene la definición de extractivismo. Para esto el autor realiza una mención especial a los debates y movilizaciones que se presentan 
actualmente en América Latina, en donde se dan resistencias ciudadanas ante emprendimientos específicos, como los distintos proyectos mineros, petroleros o agroindustriales afincados también en territorios precisos y afectando a grupos humanos particulares. Deben verse las movilizaciones como denuncia por las consecuencias que trae este tipo de extracciones a los recursos naturales, especialmente los proyectos que tienen que ver con la minería y los hidrocarburos.

Aunque su materialidad es siempre local, su organización, en el sentido político y económico, es también global. Debido a este enorme peso de las condiciones globales y los enormes volúmenes de dinero invertidos, las capacidades de las comunidades locales, e incluso de los gobiernos, para regular el extractivismo son mucho más limitadas a las que se pueden ejercer, por ejemplo, sobre las extracciones para uso local o nacional. (Gudynas, 2013, p. 5).

Para referirse al extractivismo, el autor propone como necesario que se cumplan tres condiciones simultáneamente: referidas al alto volumen y/o intensidad en la extracción, ser recursos sin procesar o con escaso procesamiento, y un destino mayormente exportador. No basta que cumpla con una o dos de ellas, sino que deben encontrarse las tres al mismo tiempo.

Gudynas (2013) advierte que el extractivismo en América Latina está causando serios problemas en los ecosistemas, debido a la contaminación de las aguas, los suelos, el aire, especialmente en áreas naturales que eran protegidas por su biodiversidad. Otro problema grave que argumenta el autor, es que el extractivismo genera fuertes impactos sociales y económicos como son el desplazamiento de las comunidades, problemas en la salud pública y fuertes transformaciones en las economías locales:

Independientemente de su extensión, por lo general, el extractivismo se expresa en nuestros países bajo las llamadas "economías de enclave". Estas se asemejan a una "isla", con escasas relaciones y 
vinculaciones con el resto de la economía nacional. Esto se debe a que buena parte de sus insumos y tecnologías son importados, una proporción significativa de su personal técnico también es extranjero, y a su vez, no nutren cadenas industriales nacionales, sino que las exportan. (Gudynas, 2013, p. 6. El resaltado no es del original)

En lo anterior, se ve reflejado cómo las contribuciones que hace el extractivismo a las economías locales o regionales por lo general son muy limitadas, y el grueso de sus ganancias queda en sus casas matrices. El autor asegura que existen componentes culturales y políticos alrededor del extractivismo. Podría hablarse de una "cultura extractivista", basada en el mito de las enormes riquezas ecológicas latinoamericanas que debían ser aprovechadas al máximo.

Igualmente se debe dejar de ver a las economías extractivistas como una "industria", porque la simple extracción de un recurso no configura una industria ya que se exportan materias primas sin pasar por procesamientos que son propios de la manufacturación. Todo esto ha generado imaginarios en las personas porque al ver el extractivismo como una industria se apunta a evocar imágenes de fábricas repletas de obreros con lo que se espera lograr la adhesión de la opinión pública. Pero todo eso es sin duda una exageración, no sólo porque esas fábricas no existen sino porque la demanda de empleo de esos emprendimientos es escaza y el valor agregado limitado.

Con este planteamiento de Gudynas sobre el extractivismo, se podría pensar que Colombia está parada en estos momentos en un extractivismo clásico, a diferencia del resto de gobiernos de la izquierda en el continente que están bajo el Neo extractivismo. El extractivismo clásico es aquel que es realizado por las empresas transnacionales y en donde el papel del Estado es secundario. Aquí el extractivismo es justificado ante la opinión pública como necesario para el progreso y para captar mayores riquezas, que sería devuelto a la sociedad 
mediante la generación de más empleos y a través de programas sociales. Sin embargo, para Gudynas esto sólo deja riqueza para los consorcios internacionales y un incumplimiento de normas sociales y ambientales para las comunidades.

Finalmente, Gudynas (2013) aporta un nuevo concepto: "extraher" o su derivado "extrahección", que obedece a la aparición de un nuevo término que tiene su origen en el vocablo latino "extrahere", donde "ex" significa fuera y "trahere" alude a quitar y arrastrar hacía sí.

Por lo tanto, extraher significa tomar o quitar con violencia, "arrancar" los recursos naturales tanto de las comunidades como de la naturaleza. Este nuevo vocablo es importante dentro de la presente investigación porque alude a una postura que aborda no sólo los recursos naturales sino los derechos humanos, en donde se evidencia la violación, que es consecuencia de estas actividades.

Otras de las consideraciones que tienen que ver con el concepto de extraer es que generalmente tiene involucradas acciones ilegales o alegales (éste último se define como aquellas prácticas que en su apariencia formal contemplan exigencias legales pero sus consecuencias son claramente ilegales, es decir, vacíos legales que son aprovechados). Precisamente sobre el caso colombiano, el autor relaciona dos ejemplos sobre extrahección, utilizando como fuente al CINEP (2012): en minería existen denuncias de trabajadores del carbón sobre derechos laborales violados, incumplimientos de leyes laborales, retenciones de salarios y beneficios, acoso laboral y sexual, prohibición de sindicalización, etc. Por otro lado, en el sector de hidrocarburos se presentan denuncias por violación de la libertad y seguridad de las personas: entre 2001 y 2011 se registraron entre afiliados sindicales 49 detenciones, 6 secuestros, 66 amenazas de muerte y 8 atentados en el país. 
Es evidente que la extrahección utiliza distintas formas de apropiarse de los recursos, que van desde silenciar a la ciudadanía hasta evitar las movilizaciones, criminalizándolas; además, se ha llegado al extremo de asesinar líderes para asegurar su implantación en el territorio. Por otro lado el autor señala que también se violan los derechos de los trabajadores con frecuencia al ser deficiente la seguridad laboral, las normas sanitarias y demás.

Con el panorama anterior, vale la pena advertir que las expectativas de los trabajadores del sector petrolero en Barrancabermeja están por encima de la realidad que genera la dinámica laboral del sector hidrocarburos, los cuales -de acuerdo a los planteamientos de Gudynas- son imaginarios que traen consigo las empresas transnacionales a través de sus economías extractivistas, porque son pocos los empleos que se generan, las riquezas por el aprovechamiento de los recursos naturales no se quedan en los territorios y menos en las comunidades. Además, porque el Estado colombiano tiene un papel difuso al utilizar sus fuerzas de seguridad para custodiar el proyecto extractivista pero no para exigir el respeto por el cumplimiento de los derechos humanos y de protección a la naturaleza.

En este sentido se podría afirmar que las economías extractivas generan un intercambio desigual en el que se hace una apropiación indiscriminada de la naturaleza, de las comunidades y del territorio, pero las riquezas no se revierten concretamente en las personas; al contrario, se evidencia que son lugares en donde la pobreza extrema tiene más presencia. 
3.5.1. Dinámica laboral del Gas y el petróleo: ¿qué las diferencia de las demás dinámicas?

Se puede plantear que, en el imaginario de las personas, en este sector está el empleo soñado. Según Michael Page, empresa de selección y reclutamiento de ejecutivos para alta y media gerencia, en "Colombia 5 de cada 10 procesos de reclutamiento de ejecutivos que se realizan tienen que ver con estas industrias". Para Ramiro Bado, gerente de la división de Petróleo y Gas de la mencionada empresa, la dinámica laboral del sector de gas y petróleo genera oportunidades laborales con altas remuneraciones y proyección profesional, esto hace que casi todos (entre gerentes y responsables de posiciones técnicas) quieran trabajar en estos sectores en la actualidad.

La investigación realizada por esta organización en 2013 evidenció que éste es el sector en el que más les gustaría trabajar a los líderes empresariales del país; incluso uno de cada dos personas estaría dispuesto a salirse del sector en el que se desempeña y cambiar principalmente a industrias como la petrolera o la de gas.

Hay otros factores que genera la dinámica laboral en el sector petrolero de acuerdo a una investigación realizada por Ávila (2009) en Yopal-Casanare. EI autor plantea una discusión en torno a los cambios estructurales, tanto en lo económico como en lo social, que generó la explotación de petróleo en este departamento.

En el documento se hace una revisión teórica sobre los fenómenos de migración y su relación con el desarrollo económico y los procesos de 
acumulación o fuga de capital humano, que al parecer es lo que ha ocurrido concretamente en el municipio de Yopal (Casanare).

El autor analiza cómo la diferencia en los salarios que ofrece el sector petrolero indujo un proceso creciente de inmigración, lo cual marginó los demás sectores de la economía del departamento. Este mismo fenómeno con el paso del tiempo introdujo modificaciones importantes en la estructura poblacional, así como un visible cambio estructural en la economía local.

En el documento se concluye que los fuertes cambios experimentados en la dinámica poblacional de Yopal asociados a la explotación de petróleo, crearon una dependencia de la economía frente a ese sector, lo cual permite visualizar las dificultades que enfrentará la población joven en el futuro cuando la explotación de petróleo termine. Con lo anterior, es propicio discernir que la dinámica laboral que genera el sector petrolero es fluctuante; esto se evidencia también en los tiempos en los que las personas que trabajan en este sector permanecen vinculadas a los proyectos y luego cuánto deben esperar para poder vincularse de nuevo.

Otro factor importante es que la dinámica laboral que se genera en este sector tiene unos roles específicos y requiere de una formación o capacitación determinada que en muchas ocasiones no se encuentra en los territorios. Sin embargo, lo que se vive en muchos municipios donde se da la extracción petrolera es que sus comunidades se capacitan específicamente sobre los requerimientos que este sector demanda en mano de obra calificada y no calificada para esperar una oportunidad de trabajo.

Por otra parte, de acuerdo al planteamiento del Centro de Investigación y Educación Popular CINEP (2012), dentro de la dinámica laboral del sector 
petrolero se generan diversos conflictos por los altos riesgos ambientales, sociales y de exacerbación de la violencia por el control de los recursos.

Con base en lo anterior, es vital reclamar el papel del Estado para dar solución a los problemas que genera sostener un modelo de desarrollo basado en las locomotoras minero-energéticas; conociendo anticipadamente las complicaciones sociales que se derivan en los territorios en donde existen proyectos extractivos, en donde las comunidades reclaman oportunidades, mejores condiciones laborales, defensa de la mano de obra local, inversión de recursos para satisfacer las necesidades básicas y la disminución del costo de vida por la desigualdad en la que viven sus pobladores. 


\section{MARCO CONTEXTUAL}

\subsection{Una mirada al municipio de Barrancabermeja, Santander}

El propósito de este apartado es hacer una breve descripción del municipio de Barrancabermeja, Santander, para contextualizar su ubicación, características demográficas, niveles de desempleo y subempleo, fuentes de empleo, las acciones contempladas en los dos planes de desarrollo que abarcan el periodo comprendido para esta investigación (2008-2014) y explicar la naturaleza del Comité de Política Pública de Empleo, de acuerdo con la temática de estudio de este trabajo de grado.

\subsubsection{Ubicación geográfica de Barrancabermeja}

Barrancabermeja está ubicado en Santander, específicamente en la Provincia de Mares, al occidente del departamento, a tan sólo $101 \mathrm{~km}$ de Bucaramanga; es considerada la segunda ciudad más importante después de la capital del departamento.

De acuerdo a la información que registra el Plan de Desarrollo Municipal (2012-2015) la ciudad está bordeada al oriente por el Río Magdalena, con una altitud sobre el nivel del mar de 75.94 Metros. La extensión total de Barrancabermeja es de 1.347,83 Km2; (IGAC, 2013). Está compuesta por 30,37 
Km2 (2,24\%) de zona urbana y 1.317,46 Km2 (97,76\%) de área rural, la temperatura promedio oscila entre los $28^{\circ} \mathrm{C}$. (PDM, 2012, p.52).

\section{Gráfica 2. Mapa municipio de Barrancabermeja (Santander)}

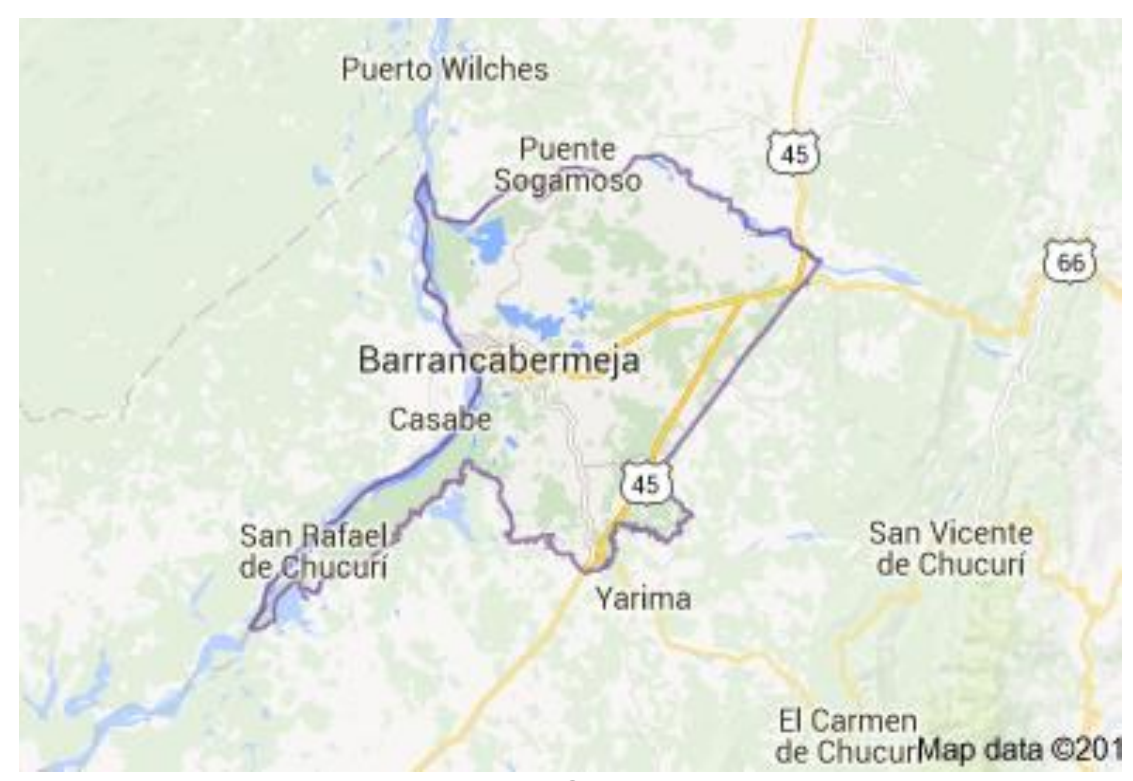

Fuente: Google maps.

El municipio limita al norte con los municipios de Puerto Wilches, Sabana de Torres y Girón, al sur con Puerto Parra, Simacota y San Vicente de Chucurí, al oriente con los municipios de San Vicente de Chucurí y Betulia; y al occidente con el municipio de Yondó (Antioquia).

Alrededor de su cabecera se encuentran los seis corregimientos que componen la zona rural del municipio, la cual equivale al $97.76 \%$ del territorio; sin embargo, ese espacio rural alberga menos del $8 \%$ del censo total poblacional.

Según el PDM (2012, p.79) la división política administrativa da cuenta que la ciudad está organizada por siete comunas compuestas por más de 300 barrios en promedio de 30 a 50 barrios cada una, el área rural está conformado por seis 
corregimientos: San Rafael de Chucurí, Ciénaga del Opón, Meseta de San Rafael, El Llanito, La Fortuna y El Centro.

\subsubsection{Características demográficas de Barrancabermeja}

La estructura socioeconómica del municipio tiene una alta dependencia de su mismo proceso histórico, el cual ha tenido distintas connotaciones con periodos de expansión relacionados al desarrollo de la industria petrolera nacional y otros de retracción como aquellos que se dieron en décadas recientes a través de los periodos de violencia en la zona del Magdalena Medio, según el PDM (2012, p. 78).

Con la dinámica empresarial de la ciudad, también migran personas de ciudades cercanas que comercializan diferentes productos, que llegan en la mañana y se van en la noche o en otros casos vienen semanalmente.

Según el informe Demográfico del CER (2012, p. 4), la cultura y tradiciones de los oriundos de Barrancabermeja está fuertemente determinada por múltiples fenómenos entre los cuales vale la pena citar la actividad petrolera, la ubicación sobre el Río Magdalena, la ubicación al centro del país, su cercanía a los departamentos de Antioquia, Cesar y Bolívar y los mega-proyectos de modernización de la refinería, de la construcción de la represa del Río Sogamoso, la construcción de la ruta del sol, la construcción del puerto multimodal, la gran vía Yuma, el dragado del Río Magdalena, entre otros.

La estructura socioeconómica de la ciudad se enlaza con su historia de explotación petrolera que se inicia con la llegada de la Tropical Oíl Company a comienzos de la segunda década del siglo XX, situación que dio pie a un proceso migratorio que fue convirtiendo el naciente caserío en corregimiento. Posteriormente en 1922 pasa a ser 
reconocida como municipio de Barrancabermeja. Es por esta historia que una de las actividades económicas principales de la ciudad gira en torno de la industria Petroquímica, ya que cuenta con la más grande refinería del país, propiedad de Ecopetrol. Sin embargo, a la par se han desarrollado otras actividades que complementan a la petrolera. (CER, 2012, p. 17)

\section{Para el CER:}

...en los últimos años Barrancabermeja ha avanzado frente a temas sociales, no obstante las cifras que se presentan esconden las inequidades que enfrenta la ciudad: de 1993 a 2005 la pobreza medida por necesidades básicas insatisfechas (NBI) pasó de 29,48\% a $22,33 \%$ ubicándose por debajo de la pobreza a nivel nacional $(27,78 \%)$, en la zona urbana para ese año fue de $20,99 \%$ mientras en la rural fue de $32,37 \%$. (2012, p.4)

Por otra parte, el PDM (2012, p.80) destaca que "el municipio de Barrancabermeja el tema demográfico se ha caracterizado por la existencia de grandes migraciones, algunas de ellas voluntarias, otras forzadas como consecuencia de la exploración petrolera y fenómeno de violencia presente en el territorio".

También dentro del PDM se indica que ese tipo de migraciones ocasiona grandes inconvenientes de tipo económico y social para el municipio, especialmente porque los problemas económicos se expresan en asentamientos en zonas de alto riesgo de desastre por inundaciones y deslizamientos debido a la ubicación en terrenos no aptos para urbanizar como las riberas del Río Magdalena, ciénagas, humedales y bajos, además, por el tipo de materiales utilizados; esto genera una deficiencia en la cobertura para la prestación de servicios públicos y otros problemas como insuficiencia de vías de acceso a estos sitios. Respecto del componente social el aumento de las migraciones ha generado un crecimiento en los niveles de desempleo y subempleo, 
manteniéndose el índice de necesidades básicas insatisfechas (salud, educación, nutrición, etc.) en $22.3 \% 8$, muy inferior al 50 a $70 \%$, rango en el que oscilan la mayoría de sus municipios vecinos. Lo cual a su vez retroalimenta el problema de migraciones encontrado en Barrancabermeja:

Entre 1973 y 2000 la población de Barrancabermeja aumentó 2,6 veces, al pasar de 99.155 a 259.882 habitantes. Los procesos migratorios (fenómeno constante en la región) durante los años cincuenta y setenta fueron alimentados por la expectativa del 'oro negro', mientras que los años ochenta y noventa por las confrontaciones armadas en los campos (García, 2006, p. 256).

Según los datos proyectados del Censo del DANE 2005, la población de Barrancabermeja se estima en 191.718 habitantes. Comparándolo con los datos de Santander, concluimos que ocupa el puesto tres de los 87 municipios que hay en el departamento y representa un 9,7078 \% de la población total de éste.

La población de Barrancabermeja está conformada por un $49 \%$ de hombres y un $51 \%$ de mujeres. De acuerdo a la edad, ésta se concentra entre los 10 y los 35 años; así mismo, los mayores de 66 años tienen la menor participación en el total de la población 6,19\%. En contraste, la población menor de 18 años representa el 19,4\%. (CER, 2013a, p. 17)

De acuerdo con la caracterización de la demanda de talento humano realizada por el CER, en el tema de educación uno de los indicadores más importantes es la tasa de analfabetismo, la cual calculada para el municipio de Barrancabermeja es de 6,8\% (EHB 2011). Adicionalmente, se señala que el 32\% de la población de 5 años y más, asiste a la escuela, colegio o universidad, y el $75 \%$ de esta población va a un establecimiento oficial. En cuanto al nivel educativo predomina la secundaria como nivel de formación máximo alcanzado. 
Con respecto a las acciones contempladas en los dos planes de desarrollo que abarcan el periodo comprendido para esta investigación (2008-2014) el primero de éstos denominado "Barrancabermeja Donde el Amor es Clave" del alcalde Carlos Alberto Contreras López (2008-2011) quien impulsó el Acuerdo 005 de 2008 para establecer la política pública de empleo y posteriormente el plan de desarrollo "En Barrancabermeja, el futuro de construye hoy" del alcalde Elkín David Bueno Altahona (2012-2015), quien continuó con esta norma regulativa para defender la mano de obra local y generar ingresos a la comunidad. A continuación se presenta un cuadro con los proyectos contemplados para materializar la PP:

Tabla 2: Planes de Desarrollo - Periodo de estudio 2008- 2014

\begin{tabular}{|c|c|}
\hline $\begin{array}{l}\text { Plan de Desarrollo: } \\
\text { “Barrancabermeja donde el Amor } \\
\text { es Clave” (2008-2011) }\end{array}$ & $\begin{array}{l}\text { Plan de Desarrollo: “En } \\
\text { Barrancabermeja, el futuro se } \\
\text { construye hoy"(2012-2015) }\end{array}$ \\
\hline $\begin{array}{l}\text { Con cuatro objetivos generales: vida } \\
\text { digna, ambiente y territorio propio, } \\
\text { productiva y competitividad } \\
\text { (desarrolla las acciones en materia de } \\
\text { empleo); y participación para la } \\
\text { inclusión. }\end{array}$ & $\begin{array}{l}\text { Con cinco ejes estructurantes: } \\
\text { específicamente sobre el tema de } \\
\text { investigación, el eje estructurante } 3 \\
\text { "Barrancabermeja ciudad región, } \\
\text { competitiva, innovadora y } \\
\text { emprendedora" }\end{array}$ \\
\hline $\begin{array}{l}\text { Objetivos específicos relacionados con } \\
\text { el desarrollo del tema: "aprovechemos } \\
\text { bien el agua" como estrategia para dar } \\
\text { un uso sostenible al agua para el } \\
\text { desarrollo social y económico de la } \\
\text { ciudad. }\end{array}$ & $\begin{array}{l}\text { El objetivo es crear las condiciones } \\
\text { propicias para la competitividad } \\
\text { empresarial y laboral, enfocada en la } \\
\text { generación sostenible de ingresos y } \\
\text { empleo, que aseguren prosperidad y } \\
\text { una mejor calidad de vida para los } \\
\text { habitantes del Municipio de } \\
\text { Barrancabermeja; fundamentada en la } \\
\text { generación de identidad de ciudad, la } \\
\text { promoción del empleo, la formalidad, el } \\
\text { emprendimiento, el empresarismo y la } \\
\text { innovación. }\end{array}$ \\
\hline $\begin{array}{l}\text { "Petróleo, bien para todos: ampliar los } \\
\text { beneficios de la producción petrolera y } \\
\text { de la industria derivada para el } \\
\text { desarrollo económico y social del } \\
\text { municipio con criterios de equidad, }\end{array}$ & $\begin{array}{l}\text { Acciones: sistema generador de } \\
\text { emprendimiento y apoyo al desarrollo } \\
\text { Empresarial, que articulará acciones de: } \\
\text { Capacitación, Asistencia Técnica, } \\
\text { Comercialización, Asociatividad, }\end{array}$ \\
\hline
\end{tabular}




\begin{tabular}{|c|c|}
\hline $\begin{array}{l}\text { inclusión social y compensación } \\
\text { socioambiental. }\end{array}$ & $\begin{array}{l}\text { financiamiento y seguimiento al } \\
\text { desarrollo empresarial y generación de } \\
\text { empleo en el Municipio. }\end{array}$ \\
\hline $\begin{array}{l}\text { "Somos más que petróleo": diversificar } \\
\text { la base económica del desarrollo } \\
\text { municipal reduciendo la dependencia } \\
\text { del petróleo y generando condiciones } \\
\text { más estables de crecimiento y empleo. }\end{array}$ & $\begin{array}{l}\text { "Aumentar la tasa de ocupación en el } \\
\text { Municipio de Barrancabermeja en } 2 \\
\text { puntos" Línea base: } 43.5 \% \text { Meta } \\
\text { cuatrienio: } 45.5 \%\end{array}$ \\
\hline $\begin{array}{l}\text { "Empleo, ingreso y mérito": aumentar la } \\
\text { oferta y la calidad del empleo y la } \\
\text { generación de ingresos, privilegiando la } \\
\text { mano de obra local y asegurando } \\
\text { mecanismos de acceso transparentes y } \\
\text { basados en los méritos de formación, } \\
\text { experiencia y calidad de cada } \\
\text { trabajador. }\end{array}$ & $\begin{array}{l}\text { Programa: "Sistema de gestión de } \\
\text { empleo para Barrancabermeja" } \\
\text { El sistema Municipal de Empleo de } \\
\text { Barrancabermeja es el proceso con el } \\
\text { cual se busca dinamiza la demanda y } \\
\text { oferta de empleo en la ciudad, con la } \\
\text { finalidad de generar más y mejores } \\
\text { oportunidades laborales para los } \\
\text { Barranqueños. }\end{array}$ \\
\hline $\begin{array}{l}\text { "Capacitémonos y organicémonos": } \\
\text { fortalecer la cualificación y la } \\
\text { organización de los barranqueños para } \\
\text { la producción económica y la } \\
\text { generación de empleo. }\end{array}$ & $\begin{array}{l}\text { Mejorar el nivel de acceso de los } \\
\text { barranqueños a la demanda de empleo } \\
\text { existente en el Municipio. Línea base: } \\
\text { ND. Meta cuatrienio: } 30 \%\end{array}$ \\
\hline $\begin{array}{l}\text { La estrategia: a aplicar consiste en el } \\
\text { fomento del crecimiento de los sectores } \\
\text { y actividades económicas intensivas en } \\
\text { mano de obra, sumado a un pacto } \\
\text { interinstitucional que involucra a los } \\
\text { principales contratantes públicos y } \\
\text { privados, para fortalecer y defender el } \\
\text { Sistema Nacional de Empleo como } \\
\text { canal único y conjunto de reglas claras } \\
\text { y justas para distribuir las } \\
\text { oportunidades y fomentar la formación } \\
\text { de la mano de obra. }\end{array}$ & $\begin{array}{l}\text { Crear una la bolsa de empleo municipal } \\
\text { para construir información oportuna, } \\
\text { permanente, confiable y actualizada } \\
\text { sobre la demanda y la oferta del empleo } \\
\text { de la ciudad, que permita dinamizar la } \\
\text { vinculación de la mano de obra local en } \\
\text { el mercado laboral. Línea base: } 0\end{array}$ \\
\hline $\begin{array}{l}\text { Acciones para la línea Sistema único de } \\
\text { Empleo: } \\
\text { - Formación por demanda anticipada } \\
\text { - } \quad \text { Estímulos al residente } \\
\text { - Plan Vida Digna control } \\
\text { - Clúster del petróleo y gas } \\
\text { - Fortalecimiento del Sistema de Empleo } \\
\quad \text { del Sena. }\end{array}$ & $\begin{array}{l}\text { Formar el recurso humano local en las } \\
\text { competencias y oficios que requiere el } \\
\text { mercado laboral identificado en la bolsa } \\
\text { de empleo. Línea base: } 1.596 \text { Meta } \\
\text { cuatrienio: } 4.096\end{array}$ \\
\hline
\end{tabular}

Fuente: Planes de Desarrollo Municipales Barrancabermeja (2008-2011 y 2012-2015) 
Con base en lo anterior, de acuerdo a la versión ofrecida por el delegado municipal en el Comité de Política Pública, Adrián Rodríguez, la inversión que se ha realizado durante el actual gobierno local se materializó con la firma de tres convenios: uno para desarrollar y ejecutar la primera fase del sistema de gestión laboral con el fin de contribuir con el acceso a las oportunidades laborales para la población de Barrancabermeja, firmado entre Ecopetrol, el Municipio, las Unidades Tecnológicas de Santander y Fundesmag por un valor que asciende los 2 mil 73 millones de pesos.

Otro convenio se firmó entre el Ministerio de Trabajo y la Alcaldía Municipal con el objeto de aunar esfuerzos técnicos, administrativos y financieros para la implementación, operación y funcionamiento del Servicio Público de Empleo en el Municipio de Barrancabermeja, Santander, en ejecución de los proyectos de inversión "Asesoría Desarrollo de un Sistema Integral de Gestión de Empleo Nacional" del Ministerio del Trabajo, e "Implementación del Sistema de Gestión de Empleo para Barrancabermeja, Santander, Centro Oriente", de Barrancabermeja, con un valor que asciende los 1 mil 379 millones de pesos.

Así mismo, se estableció el convenio entre el Municipio y la Caja de Compensación Familiar (Cafaba) con la misión de implementar, operación y funcionamiento del servicio público de empleo para la ciudad con una inversión aproximada de 1 mil 538 millones de pesos, con una vigencia de un año de duración.

Adicionalmente, con la puesta en marcha del Gran Acuerdo Social (GASB), una propuesta convocada por la Diócesis de Barrancabermeja, el Programa de Desarrollo y Paz del Magdalena Medio, Ecopetrol, la Gobernación de Santander y la Alcaldía de Barrancabermeja, que le apuesta a la construcción conjunta de un desarrollo integral para la región Magdalena Medio para impulsar cinco ejes 
temáticos como son: desarrollo del talento humano, fortalecimiento institucional, fortalecimiento económico, infraestructura para la sostenibilidad y cultura ciudadana. Entre éstos algunos relacionados directamente con el tema del objeto de estudio, con el cual se han implementado estrategias para certificación, capacitación y formación del talento humano bajo el concepto de la demanda anticipada, que se trata de analizar la demanda laboral de la región para enfocar los recursos de manera apropiada y evitar falsas expectativas en la población.

Otras estrategias implementadas con el GASB liderada por la Diócesis de Barrancabermeja tiene que ver con la formación humana en temas como ética, valores, familia, comunicación asertiva y liderazgo. Con el objetivo de brindarle al ciudadano principios para que sea honesto, tolerante, con arraigo por su tierra, responsable y respetuoso, todo en un contexto familiar. Por otra parte, la gestión interinstitucional logró establecer el Observatorio del Mercado Laboral con el liderato del CER, para dimensionar el fenómeno del trabajo de manera integral, con el propósito de convertirlo en una herramienta para la toma de decisiones.

También durante la revisión documental se encontró, que el municipio pacto mediante un anexo contractual establecer obligaciones en conjunto con Ecopetrol y sus contratistas, y entre éstos y sus subcontratistas, para que la empresa de petróleos en materia de responsabilidad social, se privilegie la vinculación de la mano de obra no profesional y profesional de las comunidades en donde se realice la extracción de los recursos.

Con lo anterior, el gobierno municipal y las entidades participantes pretendían abordar el tema del empleo de manera estructural para generar cambios en el modelo educativo de la ciudad, desarrollando procesos de emprendimiento y creando mecanismos para que la selección del personal fuera transparente, equitativo e incluyente. 


\subsubsection{Caracterización del Comité de Política Pública de Empleo}

Para la conformación del Comité de Política Pública de Empleo en Barrancabermeja, el gobierno local de la época precedido por el Alcalde Carlos Alberto Contreras López, expidió el Decreto 223 del 29 de julio de 2009, con el cual se creó el Comité Municipal de la Política de Empleo de Barrancabermeja, como instancia de articulación de la institucionalidad y los diferentes actores civiles, sociales, académicos, económicos y gremiales de la ciudad, con el objeto de realizar la evaluación y seguimiento de la implementación y cumplimiento de la política pública de empleo del Municipio de Barrancabermeja, con arreglo a lo establecido por el Acuerdo Municipal No. 005 de 2008. Dando cumplimiento a esta regulación de política, se establece la creación de dicho estamento que estará conformado por:

- Alcalde Municipal o su delegado, quien lo presidirá.

- El Secretario de Desarrollo Económico y Social, quien ejerce y ejecuta las funciones de secretaría técnica.

- Un miembro del Concejo Municipal.

- Un delegado del Ministerio de la Protección Social.

- El Subdirector (a) del SENA Barrancabermeja.

- Un representante de Ecopetrol.

- Un representante de los sindicatos.

- Un representante de las Asociaciones de Trabajadores de Barrancabermeja.

- Un representante del sector Académico y Centros de Investigaciones.

- Un representante de la Cámara de Comercio de la ciudad.

- Un representante de los Gremios económicos de la ciudad.

- Un representante de las Juntas de Acción Comunal (JAC).

- Un representante de las Juntas Administradoras Locales (JAL).

De acuerdo a lo referido en el Decreto 223 de 2009 la conformación del Comité se realizará automáticamente cuando algunas de las entidades realicen 
cambios de sus representantes. Adicionalmente, el Comité podrá invitar a cualquier funcionario del Municipio o representantes de entidades privadas con el fin de recibir asesoría o acompañamiento a determinada política o programa para despejar aspectos técnicos o especializados, quien tendrá voz pero no voto en la toma de decisiones del Comité.

Algunas de las funciones del Comité están relacionadas con establecer pautas para la implementación, adaptación, complementación y mejoramiento permanente de la Política Pública de Empleo; aprobar planes y proyectos para la implementación de la PP; reglamentar la aplicación de incentivos y estímulos especiales a los empresarios que favorezcan la PP; estudiar y revisar el cumplimiento del propósito fundamental, desarrollo y articulación de componentes de la PP; promover y generar propuestas de modificación y mejoramiento de proyectos y planes articulados a la PP; diseñar y aprobar las herramientas de seguimiento y evaluación de la PP; aprobar la implementación de acciones correctivas y preventivas orientadas al logro del propósito fundamental de la PP; evaluar el avance en el logro fundamental y la implementación de la PP; establecer su propio reglamento; y las demás que la Ley, Acuerdos Municipales o actos administrativos disponga la autoridad competente.

Finalmente, sobre este apartado el mismo Decreto 223 de 2009 refiere que el Comité de Política Pública de Empleo deberá sesionar de manera ordinaria cada dos meses, previo a la convocatoria que realice la Secretaría Técnica, que para este caso está en cabeza de la Secretaría de Desarrollo Económico y Social. Para deliberar es suficiente la presencia de al menos cinco de sus miembros y para decidir la mitad más uno de sus integrantes. 


\subsubsection{Niveles de desempleo de Barrancabermeja}

La información para realizar este apartado se refiere a la Encuesta de Hogares 2011 y 2013; y la Caracterización de la demanda del talento humano para los sectores comercio, servicios, construcción y transporte de Barrancabermeja, realizadas por el Observatorio de Mercado Laboral y el Centro de Estudios Regionales (CER) para comprender la dinámica laboral de Barrancabermeja, información que sirvió como línea de base municipal para la construcción de datos porque anteriormente no existían cifras concretas sobre el fenómeno laboral de la ciudad.

De acuerdo a los datos previos que maneja el CER, en el 2007 se estimaba según el CER en $21,2 \%$, y a nivel nacional se calculaba en $10.6 \%$ para la misma fecha (Almario, 2010). Posteriormente, con la aplicación de las Encuestas de Hogares aplicadas por el CER en los años 2011 y 2013 el desempleo en el puerto petrolero se estimaban en $16.2 \%$ y $19.9 \%$ y un subempleo del $24.1 \%$ y $26.0 \%$ respectivamente, comparándolo con las cifras de desempleo nacional en 2011 fue de $10.8 \%$ y en 2013 de $9.65 \%$ (CER, 2013a). En la actualidad, el gobernador de Santander, Didier Tavera Amado, informó que el índice de desempleo en el puerto petrolero está en el $30 \%$, debido a los bajos precios del petróleo y el fenómeno del niño (W Radio, 2016).

Basados en la última encuesta a hogares del municipio (CER, 2013a, p. 41) establece que "la población total de Barrancabermeja es de 192.368 habitantes (DANE 2013), de ésta, el $84,1 \%$ se encuentra en edad de trabajar -PET(161.810). El 51,2\% son económicamente inactivos, es decir que pueden ser: estudiantes, jubilados, ama de casa, incapacitado permanentemente o realiza actividades no laborales. El 48,8\% de la PET se encuentran en el mercado laboral 
(Ocupada o buscando trabajo)". La siguiente gráfica representa la estructura del mercado laboral de Barrancabermeja 2013:

Gráfica 3. Encuesta de Hogares urbano - rural de Barrancabermeja

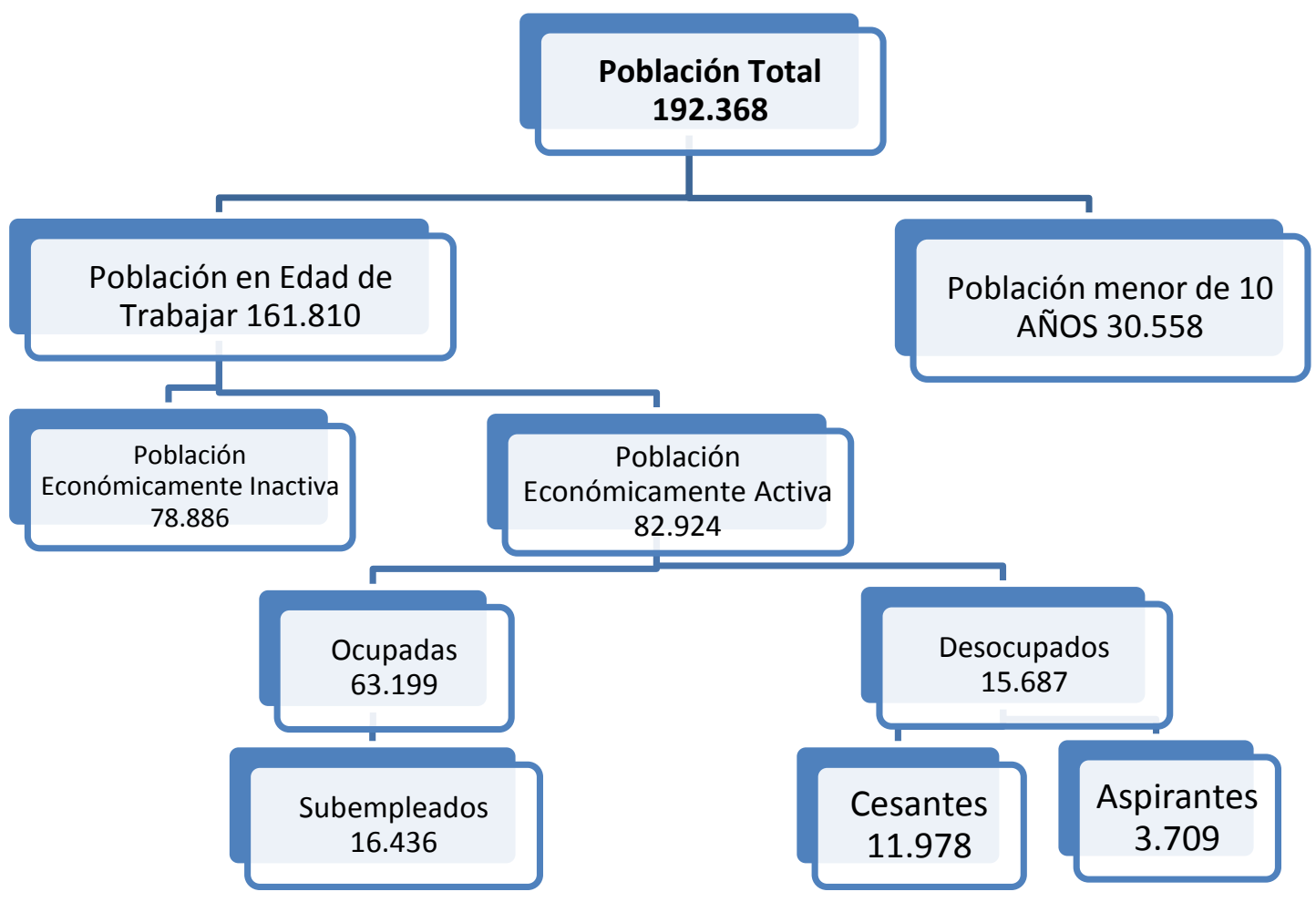

Fuente: CER (2013a, p. 41).

La mencionada encuesta también presenta los indicadores laborales de acuerdo a la zona y al sexo. Se evidenció que la Tasa Global de Participación TGP- y la Tasa de Ocupación -TO- son mayores en la zona urbana. Los hombres tienen una participación y una ocupación mayor en comparación con las mujeres. La TD es mayor en la zona rural y en las mujeres. El subempleo es mayor en la zona urbana, en donde los hombres tienen una tasa de subempleo mayor que las mujeres. En comparación, en la zona rural la tasa de subempleo es mayor 
para las mujeres. La siguiente tabla muestra los resultados de los cálculos según zona y sexo:

Tabla 3. Encuesta a Hogares urbano - rural del municipio de Barrancabermeja

\begin{tabular}{|c|c|c|c|c|c|}
\hline \multicolumn{2}{|c|}{ Zona y Sexo } & TGP & $\begin{array}{c}\text { Tasa de } \\
\text { ocupación }\end{array}$ & $\begin{array}{c}\text { Tasa de } \\
\text { subempleo }\end{array}$ & $\begin{array}{c}\text { Tasa de } \\
\text { desempleo }\end{array}$ \\
\hline \multirow{3}{*}{ Urbano } & Hombre & 61,5 & 50,8 & 25,8 & 17,3 \\
\cline { 2 - 6 } & Mujer & 38,5 & 29,7 & 26,4 & 22,9 \\
\cline { 2 - 6 } & Total & $\mathbf{4 9 , 2}$ & $\mathbf{3 9 , 6}$ & $\mathbf{2 6 , 0}$ & $\mathbf{1 9 , 6}$ \\
\hline \multirow{3}{*}{ Rural } & Hombre & 64,3 & 52,9 & 23,3 & 17,7 \\
\cline { 2 - 6 } & Mujer & 23,4 & 14,3 & 35,4 & 38,6 \\
\cline { 2 - 6 } & Total & $\mathbf{4 4 , 3}$ & $\mathbf{3 4 , 1}$ & $\mathbf{2 5 , 8}$ & $\mathbf{2 3 , 1}$ \\
\hline \multirow{3}{*}{ Total } & Hombre & 61,7 & 51,0 & 25,5 & 17,3 \\
\cline { 2 - 6 } & Mujer & 37,2 & 28,4 & 26,8 & 23,7 \\
\cline { 2 - 6 } & Total & $\mathbf{4 8 , 8}$ & $\mathbf{3 9 , 1}$ & $\mathbf{2 6 , 0}$ & $\mathbf{1 9 , 9}$ \\
\hline
\end{tabular}

Fuente: CER (2013a, p. 43).

De acuerdo a la caracterización realizada por el CER en la Encuesta a Hogares de Barrancabermeja 2013, los sectores que absorben la mayor cantidad de trabajadores son Servicios (32.2\%) que incluyen alojamiento, restaurantes, información y comunicación, actividades inmobiliarias y financieras entre otras; comercio (18.7\%) que incluye comercio al por mayor y menor; e industria (13.1\%) que incluye la refinería, el subsector metalmecánico y el textil. 
Tabla 4. Encuesta a Hogares urbano - rural del municipio de Barrancabermeja

\section{Ocupados por sector económico}

\begin{tabular}{cc|}
\hline Agropecuario & $2,5 \%$ \\
\hline Educación & $5,3 \%$ \\
\hline Transporte & $6,8 \%$ \\
\hline Minería & $9,9 \%$ \\
\hline Construcción & $11,6 \%$ \\
Industria & $13,1 \%$ \\
Comercio & $18,7 \%$ \\
Servicios & $32,2 \%$ \\
\hline
\end{tabular}

Fuente: CER (2013a, p. 50).

La misma encuesta de hogares realizada por el CER (2013a, p. 56-62), genera cifras del municipio sobre los desocupados en la ciudad, que asciende a los 15 mil, de los cuales el 24\% (3 mil) nunca han tenido un empleo, es decir, son aspirantes. Las tasas de desempleo son mayores en los jóvenes, especialmente en mujeres, donde la TD es $49 \%$ en tanto que los hombres es $30 \%$. Por comunas, la TD para las mujeres es más alta en la comuna $6(33.1 \%)$ mientras que para el caso de los hombres es en la 5 (25.4\%). Por nivel educativo, se encuentra que quienes alcanzan posgrado tienen la menor tasa de desempleo, en tanto que quienes son bachilleres, técnicos y tecnólogos tienen la TD más alta en la ciudad. Algunas cifran dan cuenta de la situación de empleo en la ciudad: 
Tabla 5. Cuadro comparativo según cifras del Fenómeno de Empleo en Barrancabermeja

\begin{tabular}{|l|l|l|l|l|l|l|l|l|l|}
\hline $\begin{array}{c}\text { Barranca/ja } \\
\text { Vs B/ga y } \\
\text { Nación } \\
\text { (2007-2013) }\end{array}$ & $\begin{array}{c}\text { Local } \\
2007\end{array}$ & $\begin{array}{c}\text { B/ga } \\
2007\end{array}$ & $\begin{array}{c}\text { Nación } \\
2007\end{array}$ & $\begin{array}{c}\text { Local } \\
2011\end{array}$ & $\begin{array}{c}\text { B/ga } \\
2011\end{array}$ & $\begin{array}{c}\text { Nación } \\
2011\end{array}$ & $\begin{array}{l}\text { Local } \\
2013\end{array}$ & $\begin{array}{l}\text { B/ga } \\
2013\end{array}$ & $\begin{array}{c}\text { Nación } \\
2013\end{array}$ \\
\hline Ocupados & N.D. & $51,2 \%$ & $51,2 \%$ & $43.5 \%$ & $64 \%$ & $56,8 \%$ & $39,1 \%$ & $\begin{array}{l}63,3 \\
\%\end{array}$ & $58,2 \%$ \\
\hline Desempleo & $21,2 \%$ & $9,3 \%$ & $11,1 \%$ & $16.2 \%$ & $9.6 \%$ & $10,8 \%$ & $19.9 \%$ & $9.4 \%$ & $9.6 \%$ \\
\hline Subempleo & N.D. & $36,3 \%$ & $34,9 \%$ & $24.1 \%$ & $\begin{array}{l}34.8 \\
\%\end{array}$ & $31,5 \%$ & $26,0 \%$ & $\begin{array}{l}34.7 \\
\%\end{array}$ & $29,3 \%$ \\
\hline
\end{tabular}

Fuente: Dane 2007-2011-2013 - CER EHB 2011-2013

Por otra parte, de acuerdo a la EHB 2013 de los más de 15 mil desocupados de la ciudad, 1.000 (7\%) durante el último año rechazaron ofertas de empleo. Las causas principales son en orden de importancia salario insuficiente y horario inadecuado. De estos mil el 33\% han rechazado hasta 5 ofertas laborales.

Los principales medio de búsqueda de quienes están desocupados son en orden de importancia: pidiendo ayuda a conocidos o familiares (39.3\%), visitando o enviando hojas de vida (36.0\%) y a través de la agencia de empleo de SENA (14.2\%).

Las tasas de informalidad más altas se concentran en los niveles educativos básicos, es decir primaria (32.0\%) y secundaria (24.7\%). Los sectores servicios y comercio son quienes concentran el mayor número de informales en la ciudad con una participación de $42 \%$ y $30 \%$ respectivamente. Seguido de lejos por construcción (8\%). 
4.1.5. Fuentes de empleo que existen en Barrancabermeja

El CER (2013b) también realizó la "Caracterización de la demanda del talento humano para los sectores comercio, servicios, construcción y transporte de Barrancabermeja". En este documento, de las mediciones establecidas, estimaron que cerca de la mitad del empleo generado en la ciudad está soportado en actividades relacionadas con el comercio al por mayor y menor, reparación de vehículos, servicios bancarios, hoteles, restaurantes, bares y actividades relacionadas con la construcción. Este último sector ha sido jalonado en el último año debido principalmente al aumento en la edificación de viviendas y hoteles. De igual manera es de reconocer que la economía de Barrancabermeja está marcada por los sectores de comercio y servicios incluyendo el transporte, los cuales agrupan el $80 \%$ de las empresas que operan en la ciudad, según registros de la Cámara de Comercio de Barrancabermeja. En este sentido la dinámica de contratación que desarrollan estos sectores genera un gran impacto en la población económicamente activa de la ciudad, especialmente para los desocupados.

Actualmente Barrancabermeja, de acuerdo al último informe de la Cámara de Comercio, cuenta con cerca de 5.500 unidades productivas de carácter formal, dónde el $64.7 \%$ de estos pertenece al comercio, $23.1 \%$ a servicios y el $12.2 \%$ a la industria.

Otro aporte importante de la EHB realizada por el CER para este proyecto de investigación, es que de las personas que residen en el municipio, el 75,8\% (146 mil personas) nacieron y llevan viviendo toda la vida el municipio:

De las 47 mil personas que son migrantes $76,7 \%$ llegaron a Barrancabermeja hace más de 5 años. Al desagregar por zona, de las personas que migraron hacia el municipio, el $91,4 \%$ reside en la zona urbana y $8,6 \%$ en la zona rural. El $53,9 \%$ de los migrantes son mujeres, 
$46,1 \%$ hombres y el $94,3 \%$ se encuentran en Edad de Trabajar. Las principales razones por las que estas personas migraron se encuentran, traslado del hogar $59,1 \%$, para trabajar $17,7 \%$ y para buscar trabajo 11,4\%. (CER, 2013a, p. 11).

Según el PDM (2012, p.33) estas relaciones mostradas han ocasionado que Barrancabermeja sea altamente dependiente de la industria petrolera en su producción y refinación, haya comenzado a transformarse en una ciudad con otros sectores adicionales que lideran las actividades económicas locales relacionadas principalmente al sostenimiento de una población que demanda servicios tales como alimentos, construcción, esparcimiento, vestuario y transporte, sin que esto signifique una disminución en la importancia de sector Petrolero, el cual concentra importantes inversiones en la ciudad. 


\section{MARCO NORMATIVO}

El marco normativo rastreado sobre la defensa a la mano de obra y la protección laboral para el sector petrolero mencionado en este proyecto, está motivado y fundamentado básicamente en los lineamientos descritos a continuación:

- Convenios ratificados por Colombia con la OIT.

- Constitución Política de Colombia 1991.

- Código Sustantivo del Trabajo.

- Jurisprudencia colombiana en la materia.

- Decretos y normas nacionales reglamentarias para el sector hidrocarburos.

- Acuerdos y decretos municipales implementados para la puesta en marcha de la política pública de empleo y la defensa de la mano de obra.

\subsection{Convenios firmados con la OIT para la protección laboral de Colombia}

A nivel mundial, la Organización Internacional del Trabajo en el marco de los derechos humanos fundamentales ha abordado todo los temas relacionados con el derecho al trabajo, puesto que el mismo permite la dignificación de la persona y su participación en la prosperidad y el progreso de la sociedad. 
Al respecto, Colombia ha ratificado 61 convenios internacionales con la OIT de los cuales sólo se encuentran vigentes 55 contenidos en los siguientes tres bloques: convenios fundamentales, convenios de gobernanza y convenios técnicos, abordando diversas temáticas como el trabajo forzoso, la libertad sindical y negociación colectiva, igualdad de remuneración, discriminación y trabajo infantil. Estos convenios son fuente principal y son aplicables directamente para resolver las controversias. Además, es importante recalcar que los convenios que integran el bloque de constitucionalidad orientan la interpretación de la norma suprema y en el sentido estricto prevalecen en el orden interno. Así serán valorados especialmente por los jueces y los funcionarios administrativos. Los convenios internacionales del trabajo debidamente ratificados hacen parte de la legislación interna.

\subsection{Principales leyes y normas generadas en Colombia para la protección laboral en el sector petrolero}

En el contexto nacional, el trabajo es un derecho fundamental que debe ser garantizado por el Estado, así lo expresa el artículo 25 de la Constitución Política de 1991: "el trabajo es un derecho y una obligación social y goza, en todas sus modalidades, de la especial protección del Estado. Toda persona tiene derecho a un trabajo en condiciones dignas y justas". Adicionalmente, el artículo 39 consagra el derecho de asociación sindical para los trabajadores y empleadores, sin intervención del Estado.

Por otra parte, el artículo 53 de la carta magna reglamentó que el Congreso expedirá el Estatuto del Trabajo bajo los siguientes principios mínimos: igualdad de oportunidades, remuneración mínima vital y móvil, proporcional a la cantidad y calidad trabajo, estabilidad en el empleo, garantía a la seguridad social, 
capacitación, adiestramiento y descanso necesario, protección especial para la mujer y el trabajador menor de edad. El Estado debe garantizar el derecho al pago oportuno.

El artículo 54 señala: "es obligación del Estado y de los empleadores ofrecer formación y habilitación profesional y técnica a quienes lo requieran. El Estado debe propiciar la ubicación laboral de las personas en edad de trabajar y garantizar a los minusválidos el derecho a un trabajo acorde con sus condiciones de salud". Seguidamente los artículos 55, 56 y 57 garantizan la negociación colectiva, el derecho a la huelga y los estímulos para que los trabajadores participen en la gestión de empresas respectivamente.

Estas disposiciones concuerdan con los tratados internacionales de los que Colombia es parte, tales como la Declaración Universal de los Derechos Humanos, el Pacto Internacional de Derechos Económicos, Sociales y Culturales, el Pacto Internacional de Derechos Civiles y Políticos, y la Convención Americana sobre Derechos Humanos.

De acuerdo al rastreo jurisprudencial, la Corte Constitucional colombiana se ha ocupado en múltiples ocasiones del tema, las cuales dan la pauta para analizar el alcance y la repercusión que este principio fundamental tiene en materia laboral, si se quiere una de las áreas vitales para el ser humano, en razón a que del trabajo depende en parte su estabilidad. Al respecto el alto tribunal ha basado sus decisiones en la necesidad de que exista igualdad en las relaciones laborales; si esta es inexistente, se cae en relaciones inequitativas.

En algunas de las sentencias sobre la constitucionalidad de los convenios internacionales de la OIT ratificados por Colombia, la Corte se pronunció: 
De ninguna manera los convenios internacionales del trabajo pueden ser considerados simplemente como parámetros supletorios en el ordenamiento laboral. Independientemente de la definición acerca de cuáles son los convenios que forman parte del bloque de constitucionalidad, es claro que todos forman parte de la legislación interna, lo que significa que no pueden ser relegados, por regla general, a parámetros supletorios de interpretación ante vacíos normativos en el orden legal. Adicionalmente, aquellos convenios que integran el bloque de constitucionalidad han de ser aplicados por todas las autoridades y los particulares para asegurarse de que las leyes nacionales sean interpretadas de manera acorde con la Constitución y tales convenios debido a que los mismos han sido adoptados (Sentencia C-203 de 2005) por diversas vías y por mandato de la propia Carta Política -entre otros en los artículos 9, 93, 94, 214, 53 y 102. (Corte Constitucional, Sentencia C-401 de 2005)

Se evidenció que sobre la jurisprudencia relacionada con las normas del trabajo en el sector de hidrocarburos no se encontraron decisiones específicas al respecto debido a que la legislación existente en materia laboral recoge la mayor parte de los temas que podrían afectar directamente al sector de hidrocarburos y por ende aplicables a las distintas formas de trabajo en todos los sectores productivos de la economía nacional.

Respecto a la normativa nacional, con el Código Sustantivo del Trabajo adoptado por el Decreto Ley 2663 del 5 de agosto de 1950, se reguló el derecho a la igualdad y su aplicabilidad en el ámbito laboral. Uno de los mecanismos instituidos para garantizarlo es mediante la expedición de normas generales que, además de regular los aspectos relativos a la prestación individual de servicios, cualquiera que sea el ámbito en que ella se desarrolle, le aseguren al trabajador una vida digna.

Dentro de los principios generales (21 artículos) el objetivo principal del Código Sustantivo del Trabajo es lograr el equilibrio en las relaciones obreropatronales, al encontrarse el trabajador desprotegido desde el punto de vista 
económico y social. Por ello se le otorga una serie de prerrogativas, como el principio de irrenunciabilidad, favorabilidad y la protección del trabajo. Luego, se resalta la definición del trabajo, que de acuerdo a este Código, es 'toda actividad humana libre, ya sea material o intelectual, permanente o transitoria, que una persona natural ejecuta conscientemente al servicio de otra, y cualquiera que sea su finalidad, siempre que se efectúe en ejecución de un contrato de trabajo". También el Código plantea la igualdad de los trabajadores, el derecho al trabajo, el derecho a la asociación y huelga, entre otros como principios rectores.

Particularmente lo referido a este proyecto de investigación, el Capítulo VIII está relacionado específicamente con los trabajadores de empresas de petróleos. Aunque no mencionada la defensa de la mano de obra local, si presenta las consideraciones que deben tener en cuenta los empleadores y trabajadores de este sector sobre las obligaciones y derechos en materia de habitación y saneamiento, alimentación y costo de vida, asistencia médica, hospitales e higiene, sobre hospitalización y medidas profilácticas, entre otras disposiciones en torno a la seguridad social. Lo anterior es obligatorio para las empresas de petróleos que realizan trabajos en lugares alejados de los centros urbanos.

Sobre las competencias territoriales, la Ley 715 de 2001 en los artículos 74 y 76, define que los departamentos en coordinación con los municipios deben "participar en la promoción del empleo y la protección de los desempleados" y "promover el empleo y la protección a los desempleados" (art. 74.15 y 76) respectivamente, por ende, Barrancabermeja estableció la política pública de empleo en el año 2008 para ser gestor y planificador de su propio desarrollo.

Por otra parte, el gobierno nacional crea en el 2004 la Agencia Nacional de Hidrocarburos $(\mathrm{ANH})$ con el objeto de administrar las reservas de hidrocarburos 
de propiedad la nación y el establecimiento de términos contractuales competitivos. La regulación específica aplicable al sector de hidrocarburos se encuentra consagrada principalmente en el Código de Petróleos, en los Acuerdos emitidos por el Consejo Directivo de la $\mathrm{ANH}$ y en los respectivos contratos para la exploración y explotación.

Con la creación de la $\mathrm{ANH}$, el interés del gobierno se centró en permitir la llega de nuevos actores, nuevas empresas que ampliaron la frontera hidrocarburífera del país, las cuales llegaron a regiones en las cuales no había presencia de actividad en campo. En otras áreas de tradición petrolera, se aumentó el número de contratos y las actividades crecieron sustancialmente, constituyéndose en un elemento fundamental para el desarrollo de las economías locales, generando impactos positivos y negativos en el entorno donde operan.

Para el año 2011, la ANH comenzó a dimensionar un proyecto para el desarrollo de la Guía Técnica Colombiana GTC250 "Buenas prácticas sociales para la exploración y la explotación de hidrocarburos". Finalmente el 17 de septiembre de 2014, la agencia presenta este documento con el fin de construir una guía que le permitiera al inversionista extranjero y nacional poder contar con los elementos mínimos para facilitar el ingreso a los territorios, el relacionamiento con las comunidades, la protección de los derechos de las mismas y su interrelación con las autoridades locales y regionales.

Otras disposiciones nacionales que tienen que ver con el tema objeto de investigación, son reglamentadas a través de los siguientes decretos:

El Decreto 2089 del 17 de octubre de 2014. Es el más relevante dentro de la temática de investigación porque con este mandato se adoptaron medidas especiales para garantizar la vinculación de mano de obra local a proyectos de 
exploración y producción de hidrocarburos. El Gobierno Nacional determinó que la totalidad de la mano de obra no calificada debe ser del municipio y con prioridad del área en que se desarrollen proyectos de exploración y producción de hidrocarburos. Sólo cuando no exista el talento humano suficiente y con los perfiles requeridos, se posibilitará la contratación de personal de municipios aledaños y en su defecto del resto del país. La mano de obra calificada como mínimo debe corresponder al $30 \%$ y debe ser residente del municipio en que se encuentre el proyecto.

Además, se puso en marcha la implementación del Servicio Público de Empleo (SPE) mediante el Decreto 0722 del 15 de abril de 2013 para ser ejecutado de manera progresiva en las regiones. Con esto se busca que el Servicio Público de Empleo genere mecanismos para que los porcentajes de mano de obra local se implementen de manera adecuada. Por eso, en los municipios en donde ya existen Centros de Empleo se fortalecerán los mecanismos para la convocatoria de personal local. Donde no existan aun centros de empleos se buscará la concertación con autoridades locales y comunidades para definir quienes operarán el Servicio de Empleo en esos municipios. Las autoridades locales, los actores sociales y empresarios serán escuchados en el proceso de implementación progresiva del SPE.

El 6 de diciembre de 2013 se expide el Decreto 2852 para reglamentar el Mecanismo de Protección al Cesante creado por la Ley 1636 de 2013, específicamente en los componentes relacionados al empleo, la capacitación para la inserción laboral, prestaciones económicas y de seguridad social.

Es preciso mencionar que la regulación del tema de la mano de obra local no es muy extenso. No obstante algunas leyes como la ley 685 de 2001 Código de Minas, en su Capítulo XXIV al mencionar algunos aspectos sociales de la minería 
en sus artículos 251, 253 y 254 contempla que los titulares de concesiones a la hora de contratar deben preferir la mano de obra local siempre que dicha mano de obra tenga las competencias y calificación laboral requerida; así mismo retoma lo planteado por la Ley 10 de 1961 en su artículo 18 sobre la igualdad de condiciones salariales para los trabajadores del sector petrolero adaptándolo para el conjunto de trabajadores de explotaciones mineras al establecer que no deberán ser remunerados en un porcentaje inferior al 70\% de la remuneración del personal calificado y no menos del $80 \%$ de la remuneración de los trabajadores ordinarios.

Así mismo, el artículo 254 establece que:

...en los trabajos mineros y ambientales del concesionario de minas la autoridad minera, oídos los interesados, señalará los porcentajes mínimos de trabajadores oriundos de la respectiva región y domiciliados en el área de influencia de los proyectos que deberán ser contratados. Periódicamente estos porcentajes serán revisables.

En concordancia con lo anterior, un trabajo que si está reglamentado es la profesión de Ingeniero de Petróleos, mediante Ley 20 de 1984. En la mencionada ley el artículo 4 establece:

...se concederán licencias especiales temporales para ejercer la profesión de Ingeniero de Petróleos en Colombia a extranjeros cuando según concepto del Consejo Profesional de Ingeniería de Petróleos, sea conveniente o necesario su concurso especialmente cuando se trate de especialidades que no existan en el país, o que existan en grado muy limitado [...]" norma que se reglamentó mediante el Decreto 1412 de 1986. 


\subsection{Acuerdos y decretos municipales generados en Barrancabermeja para la defensa de la mano de obra local y la puesta en marcha de la política pública de empleo en la ciudad}

En lo referente al tema en el contexto local, en Barrancabermeja se han generado acuerdos para la defensa de la mano de obra y la puesta en marcha de su política pública sobre empleo, que da cuenta de una necesidad histórica exigida por la comunidad desde 1985. En aquella época se originó el Acuerdo 026 con el que se creó el comité de protección al empleo. El artículo cuarto dice: "Ios contratos que celebre el Municipio con las diferentes Empresas Contratistas, debe exigir a través de una clausula especifica el empleo de mano de obra residente en el Municipio de Barrancabermeja".

Sin embargo, con el transcurrir del tiempo el problema de inmigración laboral y el desplazamiento de la mano de obra local se agudizaron en la ciudad. Es así como el 30 de mayo de 2008 se expide el Acuerdo 005 con el que se establece la política de empleo, generación de ingresos y defensa de la mano de obra barrameja.

Sobre éste último, el artículo quinto define:

...toda entidad del sector público que desarrolle procesos de selección de contratistas, establecerá una puntuación en calificación final o los oferentes que garanticen la vinculación de la mano de obra local en un mínimo del $80 \%$ del total de puestos de trabajo que se generen en la ejecución de dicho contrato. Si dicho contrato se ejecuta en forma directa por el adjudicatario, bajo la figura de subcontratación, el subcontratante también quedara sujeto a respeto de la obligación establecida en este artículo. 
Posteriormente, el 2 de julio de 2009 se emite el Decreto 223 con el cual se conforma el Comité Municipal de la Política de Empleo para Barrancabermeja, con el objeto de articular los diferentes actores civiles, sociales, académicos, económicos y gremiales de la ciudad para realizar la evaluación y seguimiento de la implementación y cumplimiento de la política pública de empleo del Municipio de Barrancabermeja.

En función a estas regulaciones, el 4 de abril de 2013 se genera el Decreto 080 con el que se reglamenta la expedición de la certificación para acreditar la residencia de aquellas personas que viven en el territorio del área de influencia de los proyectos de exploración y explotación petrolera y minera en general, que aspiren a acceder a labores en mano de obra no calificada y calificada. Luego con el Decreto 220 del 7 de Octubre 2013 se establece el procedimiento para la obtención de dicho certificado de territorialidad, teniendo en cuenta los siguientes componentes: cédula con expedición en Barrancabermeja, pago del impuesto predial, vinculación como estudiante o con hijos estudiando (mínimo dos años consecutivos) en planteles educativos, estar en la base de datos del Sisben y en el censo electoral de 2011. Siempre y cuando se cumpla con algunos de los anteriores requisitos, la Secretaría de Gobierno podrá verificar y expedir el certificado en tres días hábiles. 


\section{MARCO METODOLÓGICO}

Con base en el Acuerdo 005 de 2008 con el cual se establece la política pública de empleo, generación de ingresos y defensa de la mano de obra de Barrancabermeja, el presente trabajo de investigación pretende analizar la política y las percepciones de los diversos actores involucrados en el Comité que hace control, seguimiento y evaluación a esta política, específicamente en el componente defensa de la mano de obra local para el sector petrolero, con el propósito de conocer la contribución para el mejoramiento del desarrollo local del periodo comprendido entre los años 2008 y 2014.

La metodología se realizó mediante un estudio explicativo con enfoque cualitativo, para brindar diferentes posibilidades en su abordaje, técnicas, interpretación y análisis de la información del objeto de estudio, mediante la utilización de diferentes estrategias para conocer de la propia fuente de información lo que piensa, siente y lo que espera en este caso de la política pública de empleo de Barrancabermeja. El trabajo de campo se realizó en dos fases: una primera visita de acercamiento y luego, en el mes de septiembre de 2014 se aplicaron los instrumentos que dan cuenta de las categorías de análisis con las que se abordó este proyecto de investigación fueron: políticas públicas (implementación y territorialización), trabajo y/o empleo (mano de obra calificada y no calificada), desarrollo local y desarrollo para el empleo y economías extractivas, con el objetivo de explicar bajo argumentos teóricos estos conceptos y generar un análisis de las percepciones de los miembros del Comité de Política Pública durante el proceso de implementación del Acuerdo 005 de 2008. 


\subsection{Técnicas de investigación}

Las principales técnicas de recolección de información son las entrevistas semi-estructuradas (ver anexo) y la revisión documental para analizar la política de empleo y su aporte al desarrollo local a partir de las percepciones de los integrantes del Comité de Política Pública de Empleo de Barrancabermeja; para conocer en palabras de los entrevistados la situación de empleo de la ciudad; el surgimiento, puesta en marcha, aciertos, desaciertos y retos de la política pública de empleo; expresar una definición sobre defensa de la mano de obra local y su visión sobre este componente en la realidad social, así como establecer si ésta ha contribuido al desarrollo local del Puerto Petrolero.

La revisión documental, incluye los acuerdos generados para la defensa de la mano de obra local (Acuerdo 026 de 1985 y Acuerdo 005 de 2008), los decretos que se generaron para la implementación de la Política Pública de Empleo de Barrancabermeja, las principales normas que regulan la contratación de la mano de obra local en sectores donde se realizan extracciones de petróleo, los planes de desarrollo generados en el periodo de estudio, entre otros.

\subsection{Muestra}

La selección para la práctica de entrevistas semi-estructuradas tuvo en cuenta un método discrecional, en donde se escoge una muestra representativa de cada uno de los grupos poblacionales que conforman el Comité de Política Pública, como sus voceros en esta instancia de evaluación, seguimiento y 
control. Adicionalmente, era preciso contar con el concurso de cada una de las personas identificadas, para atender la entrevista.

Las personas a las que se les realizó la entrevista fueron definidos, especialmente con la intención de contar con un representante de la Alcaldía Municipal, Ecopetrol, Sindicatos, Juntas de Acción Comunal JAC, Juntas Administradoras Locales JAL, Sector Académico o Centros de Investigación y Asociaciones de Trabajadores, entre otros. En la siguiente tabla, se presenta la caracterización de los entrevistados:

Tabla 6, Actores entrevistados, miembros del Comité de Política Pública de Empleo de Barrancabermeja

\begin{tabular}{|c|c|c|c|}
\hline $\begin{array}{l}\text { SECTOR QUE } \\
\text { REPRESENTA }\end{array}$ & NOMBRE & $\begin{array}{l}\text { ARRAIGO CON } \\
\text { EL TERRITORIO }\end{array}$ & CARGO \\
\hline $\begin{array}{l}\text { Alcaldía } \\
\text { Municipal }\end{array}$ & $\begin{array}{l}\text { Angélica } \\
\text { Suárez Serrano }\end{array}$ & $\begin{array}{l}\text { Nacida y criada } \\
\text { en la ciudad }\end{array}$ & $\begin{array}{l}\text { Secretaria Privada } \\
\text { delegada del Alcalde }\end{array}$ \\
\hline $\begin{array}{l}\text { Alcaldía } \\
\text { Municipal }\end{array}$ & $\begin{array}{l}\text { Adrián Mauricio } \\
\text { Rodríguez } \\
\text { Gambín }\end{array}$ & $\begin{array}{l}\text { Nacido y criado } \\
\text { en la ciudad }\end{array}$ & 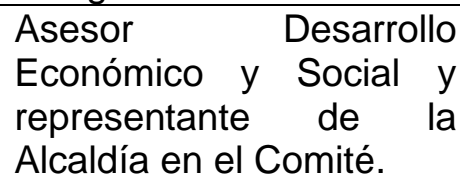 \\
\hline $\begin{array}{l}\text { Alcaldía } \\
\text { Municipal }\end{array}$ & $\begin{array}{l}\text { Darlinson } \\
\text { Rendón } \\
\text { Córdoba }\end{array}$ & $\begin{array}{l}\text { Nacido y criado } \\
\text { en la ciudad }\end{array}$ & $\begin{array}{l}\text { Profesional Especializado } \\
\text { en Sistema de Gestión } \\
\text { Laboral (SIGLA) }\end{array}$ \\
\hline Ecopetrol & $\begin{array}{l}\text { Alba } \\
\text { Amaya } \\
\text { Gutiérrez } \\
\end{array}$ & $\begin{array}{l}\text { Llegó a la } \\
\text { ciudad en } 1987\end{array}$ & $\begin{array}{l}\text { Profesional en Gestión } \\
\text { Social. }\end{array}$ \\
\hline $\begin{array}{l}\text { Unión Sindical } \\
\text { Obrera, (USO) }\end{array}$ & $\begin{array}{l}\text { Ernesto Arias } \\
\text { Rodríguez }\end{array}$ & $\begin{array}{l}\text { Nacido y criado } \\
\text { en la ciudad }\end{array}$ & $\begin{array}{l}\text { Secretario de Seguridad } \\
\text { Social y Medio Ambiente }\end{array}$ \\
\hline $\begin{array}{l}\text { Unión Sindical } \\
\text { Obrera, (USO) }\end{array}$ & Ignacio Vecino & $\begin{array}{l}\text { Nacido y criado } \\
\text { en la ciudad }\end{array}$ & $\begin{array}{l}\text { Dirigente sindical de la } \\
\text { USO }\end{array}$ \\
\hline $\begin{array}{l}\text { Juntas } \\
\text { Administradoras } \\
\text { Locales }\end{array}$ & $\begin{array}{l}\text { Pedro Antonio } \\
\text { Barrera Flórez }\end{array}$ & $\begin{array}{l}\text { Nacido y criado } \\
\text { en la ciudad }\end{array}$ & $\begin{array}{l}\text { Representante de las JAL } \\
\text { y miembro del Comité } \\
\text { Conciliador en Equidad. }\end{array}$ \\
\hline $\begin{array}{l}\text { Juntas de Acción } \\
\text { Comunal y } \\
\text { delegado de la } \\
\text { Personería } \\
\text { Municipal. }\end{array}$ & $\begin{array}{ll}\text { Miguel } & \text { Nieto } \\
\text { Machuca } & \end{array}$ & $\begin{array}{l}\text { Nacido y criado } \\
\text { en la ciudad }\end{array}$ & $\begin{array}{l}\text { Presidente de la JAC del } \\
\text { Barrio Pueblo Nuevo y } \\
\text { delegado de la Comuna } 2 .\end{array}$ \\
\hline
\end{tabular}




\begin{tabular}{|c|c|c|c|}
\hline $\begin{array}{l}\text { Universidades - } \\
\text { Sector } \\
\text { Académico }\end{array}$ & $\begin{array}{l}\text { Cristina Cecilia } \\
\text { Arenas } \\
\text { Sepúlveda }\end{array}$ & $\begin{array}{l}\text { Llegó a la } \\
\text { ciudad en } 1975\end{array}$ & $\begin{array}{l}\text { Coordinadora del Centro } \\
\text { de Investigaciones de la } \\
\text { Universidad Cooperativa } \\
\text { de Colombia (UCC) }\end{array}$ \\
\hline $\begin{array}{ll}\text { Centros } & \text { de } \\
\text { Investigación }\end{array}$ & $\begin{array}{l}\text { Diana } \\
\text { Estupiñán }\end{array}$ & $\begin{array}{l}4 \text { años viviendo } \\
\text { en la ciudad }\end{array}$ & $\begin{array}{ll}\text { Coordinadora } & \text { del } \\
\text { Observatorio de Mercado } \\
\text { Laboral del } \\
\text { Estudios } & \text { Regionales de } \\
\text { (CER) } & \end{array}$ \\
\hline $\begin{array}{l}\text { Asociaciones de } \\
\text { Trabajadores }\end{array}$ & $\begin{array}{l}\text { Jenaro Pedroso } \\
\text { Sánchez }\end{array}$ & $\begin{array}{l}\text { Nacido y criado } \\
\text { en la ciudad }\end{array}$ & $\begin{array}{l}\text { Representante Legal de la } \\
\text { Corporación la Malla } \\
\text { Barranqueña. }\end{array}$ \\
\hline $\begin{array}{l}\text { Asociaciones de } \\
\text { Trabajadores }\end{array}$ & $\begin{array}{l}\text { Armando } \\
\text { Augusto Vargas } \\
\text { Rincón }\end{array}$ & $\begin{array}{ll}10 & \text { años } \\
\text { viviendo en la } \\
\text { ciudad }\end{array}$ & $\begin{array}{l}\text { Presidente de la } \\
\text { Asociación Gremial de } \\
\text { Aisladores Térmicos y } \\
\text { Refractaristas Industriales } \\
\text { de Barrancabermeja. } \\
\text { Líder de la Junta de } \\
\text { Acción Comunal del } \\
\text { Barrio Nuevo Milenio y } \\
\text { delegado de la Red de } \\
\text { Veeduría Departamental } \\
\text { de Santander y laboral de } \\
\text { Barrancabermeja. }\end{array}$ \\
\hline
\end{tabular}

Fuente: Elaboración Propia

En general, las personas interrogadas están directa 0 indirectamente involucrados con la implementación de la Política Pública, son 4 mujeres y 8 hombres algunos profesionales, tecnólogos, técnicos y otros con nivel básico de bachillerato. De acuerdo a la información suministrada por el representante de la Alcaldía Municipal, Adrián Rodríguez, las personas entrevistadas son los miembros que participan activamente en la puesta en marcha de la política pública de empleo a través del Comité que se creó para su materialización. Cada una de estas personas conoce la problemática de empleo y vinculación de mano de obra de la ciudad al sector petrolero de primera mano, de allí la importancia de sus percepciones para el desarrollo de esta investigación. 


\section{MARCO DE ANALSIS}

La situación de empleo y las problemáticas de la ciudad de acuerdo a la totalidad de los entrevistados es compleja, porque son muchas las expectativas frente a mejores condiciones laborales y altos salarios que se generan entorno a la industria del petróleo, en cuanto allí se ubica la Refinería de Ecopetrol, pero para su infortunio y de acuerdo a los resultados de las últimas Encuesta de Hogares (CER 2011 - 2013), se evidenció que el desempleo es del 19,9\% y una tasa de subempleo del $26,0 \%$.

La última Encuesta de Hogares (CER, 2013a) demostró que la cifra para los meses de julio y agosto del desempleo es del 19,9\%, de ese mismo año, mientras que la tasa de desempleo de Bucaramanga era del $9 \%$ y del país del $9,5 \%$ en aquel momento.

Estas encuestas permitieron tener información primaria sobre la situación del empleo en la ciudad, porque la falta de información generaba especulaciones que no permitían tener de primera mano los datos para conocer la situación de empleo de la ciudad. Eso permitió que el ente gubernamental y las instituciones reconocieran la necesidad de llevar a cabo estas mediciones para realizar por lo menos una cada año en el sector rural y urbano del Puerto Petrolero. Al respecto Diana Estupiñán quien maneja el Observatorio de Mercado Laboral y trabaja para el CER, señala: 
Barranca tiene la mayor tasa de desempleo, la menor tasa de ocupación, la menor tasa global de participación, pero bueno es una de la ciudades con menor tasa de informalidad, aquí la formalidad es mucho más alta, a diferencia de Bucaramanga, aquí la informalidad es del $23 \%$ mientras que en Bucaramanga es del $53 \%$, entonces ese es uno de los pocos indicadores buenos para la ciudad. (2014, 23 de septiembre. Entrevistado por Merlano, L., Barrancabermeja)

De otra parte, cuando se indagó sobre la situación de empleo, varios de los entrevistados, quiénes se encuentran involucrados directamente con las entidades gubernamentales e instituciones, manifiestan que la situación de empleo está ligado a dos frentes en la ciudad: uno que corresponde al que se genera por la industria petrolera y otro el que resulta de diferentes actividades "comunes y corrientes" derivadas del comercio y el sector servicios "desde esta perspectiva, la situación se torna en dos lugares, los bien remunerados y los que superan el salario mínimo o simplemente el mínimo, en una ciudad donde todo se tasa desde los salarios o sueldos de la industria de los hidrocarburos" (Cristina Arenas, 2014, 23 de septiembre. Entrevistado por Merlano, L., Barrancabermeja).

Lo anterior, de acuerdo a las percepciones de los entrevistados ha generado un desempleo "voluntario" porque se conocen casos de personas que no aceptan los trabajos debido a que los salarios son inferiores a los que se ofrecen en el sector de petróleo o en la Refinería, afirma Darlinson Rendón Córdoba, profesional especializado en Sistema de Gestión Laboral (SIGLA). Otras percepciones al respecto del tema:

Hoy en día una persona no tiene un trabajo, pero le ofrecen otro de iguales características pero con un salario más bajo, y aquí en Barrancabermeja se da que esa persona no lo acepta porque las condiciones salariales no se dan y prefiere seguir así dos o tres meses sin trabajo hasta esperar la oportunidad que se ajuste a su necesidad económica. (Darlinson Rendón, 2014, 18 de septiembre. Entrevistado por Merlano, L., Barrancabermeja) 
... sabemos que alrededor de 1.300 personas, es decir el $7 \%$ de los 15.000 desempleados, han rechazado hasta 5 ofertas de empleo principalmente por el sueldo, sabemos que alrededor de 15.000 personas también no están haciendo nada, técnicamente ellos se llaman los NINI, ni trabajan, ni estudian, ni nada y eso es preocupante. (Diana Estupiñán, 2014, 23 de septiembre. Entrevistado por Merlano, L., Barrancabermeja)

Esta preocupación lleva a pensar que muchos de los pobladores no desarrollan un proyecto de vida con base al trabajo en otros sectores formales de la economía; por el contrario, puede permanecer el tiempo suficiente sin empleo hasta esperar la oportunidad en el sector petrolero para ganar los ingresos que allí se pagan. Algunos entrevistados, por ejemplo, los representantes de la USO, sindicato de Ecopetrol, y el de los trabajadores que están por fuera de la estatal petrolera, tienen en su imaginario una expectativa por los beneficios que se ofrecen desde el sector de hidrocarburos. Señalan que el hecho que llegue gente foránea les quita las oportunidades, esto hace que sea más difícil que la gente nativa se vincule directamente con la empresa, que en la actualidad se realiza a través de la intermediación ó outsourcing. Armando Vargas, miembro de la asociación gremial de aisladores térmicos y refractaristas industriales de Barrancabermeja, en la entrevista indica: “...el sector empresarial siempre busca el recurso humano fuera de esta región y a cambio nos dejan a nosotros una serie de inclemencias, el ambiente bien contaminado, nos deja pobreza y flagelo social porque ellos no dan esa oportunidad" (2014, 24 de septiembre. Entrevistado por Merlano, L., Barrancabermeja).

Otros son los argumentos de los representantes de la Alcaldía Municipal, quienes aseguran que con las Encuestas de Hogares aplicadas, se detectó que "lamentablemente gran parte del talento humano local no cumple las expectativas de las empresas contratistas, ósea no están formados debidamente, entonces teniendo en cuenta esos aspectos y teniendo en cuenta que siempre la excusa de las empresas contratistas es esa, que la calidad de la mano de obra local es 
mala, por eso fue que se iniciaron los procesos de formación con el Sena", dijo Angélica Suárez, Secretaria Privada de la Alcaldía Municipal. Pese a los esfuerzos que argumentan desde el ente municipal, la inconformidad aún se considera en las percepciones de los representantes de los trabajadores y miembros de las JAC y JAL:

...en el 2013 logramos hacer una caracterización de esos 4 sectores (comercio, servicios, transporte e industria del petróleo), un trabajador, que $76 \%$ no llegan más allá del bachillerato, son trabajadores que ganan muy poco en comparación por ejemplo con la industria petrolera y ese es uno de los motivantes o las razones por las cuales no miran casi los otros sectores. Son trabajadores que tienen mejores condiciones desde la protección laboral, porque la mayoría tienen trabajo a contrato indefinido, tienen unas prestaciones sociales etc..., tienen unas mejores garantías de estabilidad en el tiempo. (Diana Estupiñán, 2014, 23 de septiembre. Entrevistado por Merlano, L., Barrancabermeja)

Es claro, para la mayoría, que las expectativas y la demanda sobrepasan la capacidad que se ofrece en materia de empleo para la ciudad dentro del sector petrolero. La Encuesta de Hogares referida anteriormente demostró que Ecopetrol no es la principal generadora de oportunidades para los habitantes de Barrancabermeja; todo lo contrario, como lo argumenta Diana Estupiñán desde el Observatorio del Mercado Laboral y del CER:

... de los 63.000 empleos que se generan en la ciudad, alrededor del $16 \%$ es generado por Ecopetrol a través ya sea de transporte, de la refinación o de la explotación petrolera, más allá de eso, no genera más empleo. Sin embargo, la expectativa o la demanda para el sector es mucho mayor y eso lo demuestran también los indicadores, ¿quiénes generan el empleo en la ciudad? por lo general el sector comercio, servicios, transporte, es donde está el grueso de trabajadores y del cual no sabíamos nada antes de 2011. (2014, 23 de septiembre. Entrevistado por Merlano, L., Barrancabermeja) 
Para los miembros del Comité de la Política Pública de Empleo desde la mirada estatal, esto fue una sorpresa, porque no esperaban contar con estas cifras arrojadas por la Encuesta de Hogares. Incluso, aseguran que no entienden la dinámica que se presenta en la ciudad respecto de la situación de empleo, porque en una ciudad con una tasa de desempleo tan alta, los bienes y servicios deberían bajar y esto no pasa, al tener una inflación tan alta como lo argumentan:

...la política pública está enfocada a la protección de la mano de obra local, pero encontramos que si hay fuentes de empleo, en estos 4 sectores, encontramos que en 2013 habían 8.000 vacantes, entonces qué pasa en el mercado, es decir realmente el problema es que llega gente de afuera? O realmente es que las personas están sólo pensando en contratar en un sector?, (Diana Estupiñán. 2014, 23 de septiembre. Entrevistado por Merlano, L., Barrancabermeja)

Con esta información pública arrojada por la Encuesta de Hogares 2011 y 2013, los miembros que representan a trabajadores y comunidad en general del Comité de la Política Pública de Empleo de Barrancabermeja insisten que la situación del empleo en el Puerto Petrolero es "bastante caótica", pese a las políticas implementadas para defender la mano de obra calificada y no calificada, se sigue prefiriendo al foráneo, de acuerdo a las percepciones.

Respecto, de la pregunta sobre si en Barrancabermeja existen las suficientes fuentes de empleo para la población en edad de trabajar, las respuestas de siete personas es que no (entre las 12 entrevistadas), Alba Luz Amaya de Ecopetrol dice: "definitivamente esa es la razón por la cual seguramente el desempleo es tan alto" (2014, 19 de septiembre. Entrevistado por Merlano, L., Barrancabermeja), otros piensan que las únicas fuentes de empleo en la ciudad son la Alcaldía y Ecopetrol.

No, de hecho las personas de Barrancabermeja e incluso las que llegan a buscar empleo, esa migración se ve por la esperanza de encontrar un trabajo en la industria; pero está demostrado que dentro 
de los trabajos petroleros no hay empleo para todas las personas y de hecho, la sobreoferta se ve reflejada en eso, no hay cupos de empleo para todos" (Adrián Rodríguez, 2014, 18 de septiembre. Entrevistado por Merlano, L., Barrancabermeja)

Ante esta situación, la propuesta de la Secretaria Privada de la Alcaldía es que el Puerto Petrolero debe diversificar su economía, generar nuevas fuentes de empleo para los habitantes de la ciudad que esperan una oportunidad para emplearse. Esto ha generado que el ente estatal jalone algunos macroproyectos enfocados al multimodalismo, a la construcción, incluso hablan de reactivar el Río Magdalena como una fuente de trabajo y sacar beneficio del territorio para aprovechar la Ruta del Sol, una importante vía que pasará cerca del municipio y que esto debe ser explotado por el sector hotelero y turístico de la ciudad.

Lo mismo piensan los representantes de la USO, quienes dicen que es necesario utilizar los recursos que genera el sector petrolero, es decir aprovechar sus derivados para crear fábricas que den oportunidades a la mano de obra local cesante.

...se requiere que la clase política y todos nosotros empecemos a desarrollar otras actividades, ósea aquí sale una gran materia prima para hacer muchos productos y esto lo hemos planteado tanto en el Concejo Municipal como en varias partes en donde nos ha tocado hablar del tema, que es un tema bastante importante, (Ernesto Arias, 2014, 20 de septiembre. Entrevistado por Merlano, L., Barrancabermeja)

Lo anterior les preocupa, porque las oportunidades las siguen esperando únicamente del sector petrolero que genera la Refinería de Ecopetrol, aunque son conscientes que las vacantes en este renglón de la economía se dan en los momentos en los que surgen proyectos dentro de esta factoría:

...la expectativa se genera a raíz de los proyectos de la Refinería y en la empresa hay un tope de personal que tienen que emplear y por lo general hay mucha mano de obra y la demanda es muy poca y esto 
genera mucho desempleo, un caos, genera violencia, ladronismo, entonces esa expectativa se genera con base a que dicen que es la mejor Refinería del país, (Pedro Barrera, 2014, 22 de septiembre. Entrevistado por Merlano, L., Barrancabermeja)

Por otra parte, los otros cinco entrevistados aseguraron que en Barrancabermeja si existen suficientes fuentes de empleo, y las respuestas tienen que ver con los perfiles de los empleados y los tiempos que duran los trabajos; algunos son más optimistas porque piensan que el territorio tiene las potencialidades para los proyectos planeados en la nación y el municipio. Hay quienes piensan que llega mano de obra foránea y que resulta necesario un ordenamiento en la ciudad para que las oportunidades los beneficien a todos. Por último indican que la oferta de empleo es variada pero la demanda sólo le apunta a las oportunidades del sector petrolero. A continuación algunos comentarios:

...hay bastantes oportunidades, pero lastimosamente los empresarios que vienen de afuera, los inversionistas, buscan es el recurso humano de afuera. (Armando Vargas, 2014, 24 de septiembre. Entrevistado por Merlano, L., Barrancabermeja)

...suficientes si se trata de dar empleo por unos meses, pocos, rotativo; hoy tiene trabajo y en dos meses no. Lo otro es, el concepto de habitantes; puesto que el municipio es un territorio de habitantes residentes, de paso, flotantes, entre otros. (Cristina Arenas, 2014, 23 de septiembre. Entrevistado por Merlano, L., Barrancabermeja)

...si hay empleo, lo que pasa es que no todo el mundo quiere trabajar en otro lado que no sea el sector petrolero, para mí si hay empleo. (Diana Estupiñán, 2014, 23 de septiembre. Entrevistado por Merlano, L., Barrancabermeja)

La situación de empleo es compleja, de acuerdo a las percepciones generalizadas de los entrevistados, no sólo por los niveles de desempleo que registra la Encuesta de Hogares aplicada por el CER (2011 - 2013) sino porque la industria del petróleo genera expectativas que sobredimensionan la realidad 
de las vacantes. Es claro que existe una división generada en la dinámica laboral del territorio: por un lado las personas que trabajan servicios bancarios, hoteles, restaurantes, bares y actividades relacionadas con la construcción y por otro las personas que esperan una oportunidad para ingresar a Ecopetrol o a través de empresas contratistas debido a los salarios y prestaciones, esto sin importar cuanto tiempo dura cesante.

Lo anterior, no permite una construcción de proyectos de vida entorno al empleo. Pese a los esfuerzos locales por la generación de estrategias para que se vincule la mano de obra local a los proyectos petroleros, la percepción es que aún se da preferencia al que "viene de afuera"; sin lugar a duda bajo estos argumentos se torna complicado emprender un modelo de desarrollo local que propenda por mejorar las condiciones de las personas que buscan mediante el empleo tener bienestar para su vida.

En suma, uno de los problemas más sentidos, de acuerdo a los argumentos, es que la mano de obra local no se emplea, como si existiera una resistencia con los trabajadores de la ciudad.

Desde sus inicios, Barrancabermeja ha sido una ciudad que se ha caracterizado y se ha distinguido por exigir, reclamar y hacer respetar sus derechos, eso nos ha hecho ganar el estigma que somos conflictivos, problemáticos o que de pronto seamos personas que realmente formamos problemas por todo, eso conlleva que las empresas creen que trayendo personal de afuera solucionan su problema. (Jenaro Pedroso, 2014, 24 de septiembre. Entrevistado por Merlano, L., Barrancabermeja)

Así como él, las percepciones de Angélica Suarez y Darlinson Rendón, representantes del ente municipal son similares.

...no se ha creado un ambiente de confianza entre los grandes empleadores y la mano de obra local, no existe ese ambiente de 
confianza, los grandes empleadores traen sus gentes de otras ciudades y precisamente por eso es la lucha que nosotros tenemos, ya que no se pudo por la conciliación entonces toca por la vía de las normas, por la vía de la institucionalidad, para que esas personas contraten la mano de obra local. (Angélica Suarez, 2014, 18 de septiembre. Entrevistado por Merlano, L., Barrancabermeja)

...la mayoría de los barranqueños nos han marcado porque nuestros familiares o nuestros vecinos de la época de los 90 y 80 tenían una forma diferente de luchar por sus ideales laborales, hoy en día tenemos nuevas generaciones que estamos trabajando con el dialogo a través de las instituciones, pero el estigma de ser barranqueños hace que los empresarios ya tengan su mano de obra lista, traída de otra ciudad para ejecutar sus labores en Barrancabermeja. (Darlinson Rendón, 2014, 18 de septiembre. Entrevistado por Merlano, L., Barrancabermeja)

Otro de los factores sobre la problemática de empleo está asociado con la falta de una política sobre desarrollo económico para la ciudad. Según los testimonios, esto se evidencia con la llegada de nuevos proyectos en los que el municipio no está preparado, así lo afirma Adrián Rodríguez:

...no tenemos una política que incentive la inversión privada en esta ciudad, entonces estamos en mora de esa construcción, si tenemos la defensa la mano de obra local como un clamor o como una solución a una situación de intermediación laboral que se presenta en las zonas petroleras, pero hasta ahí llega, no tiene un alcance que vaya más allá, que genere nuevas fuentes de empleo diferentes a las que ya existen. (2014, 18 de septiembre. Entrevistado por Merlano, L., Barrancabermeja)

Por su parte, Cristina Arenas, representante del Centro de Investigación y Universidades, delegada de la academia, asegura que la problemática es compleja debido a que la extracción del "oro negro" encarece el nivel de vida para las comunidades ajenas a esta dinámica en la ciudad. Esto hace que se requiera con urgencia "políticas públicas para que la desigualdad de los tipos de salarios se iguale de alguna manera desde lo social para que las personas no busquen 
siempre ingresar a la industria petrolera" (2014, 23 de septiembre. Entrevistado por Merlano, L., Barrancabermeja)

Otra causa mencionada obedece al bajo nivel educativo de la ciudad, de acuerdo con el testimonio de Angélica Suárez, Secretaria Privada de la Alcaldía, con quien coincide Diana Estupiñán del CER:

...el nivel de educación en Barrancabermeja es muy bajo lamentablemente, es muy bajo, incluso muy pocas personas alcanzan la formación técnica, las estadísticas indican que más o menos el $75 \%$ de los barranqueños y el $80 \%$ tienen máximo bachillerato, sólo el $20 \%$ tiene técnica profesional o posgrado y partamos de ahí esa es la principal problemática. (Angélica Suárez, 2014, 18 de septiembre. Entrevistado por Merlano, L., Barrancabermeja)

...muchas personas acá que creen que con una técnica ya tienen, es decir la industria petrolera requiere de una mano de obra excelente y una mano de obra que no se equivoque, porque los procesos de ellos son en tiempo real y requieren de unas capacidades, unas habilidades y unos conocimientos. (Diana Estupiñán, 2014, 23 de septiembre. Entrevistado por Merlano, L., Barrancabermeja)

Al respecto, se consultó la Encuesta de Hogares aplicada por el CER para el año 2011. De acuerdo a las cifras la tasa de analfabetismo del municipio se calcula en $6,8 \%$. En la tasa desagregada por zonas, se encuentra un porcentaje de $11,2 \%$ en el sector rural de la ciudad, mientras que la parte urbana es del $6 \%$. El nivel educativo del jefe del hogar no supera la educación básica secundaria y media (44\%).

Para el año 2013, el CER aplicó nuevamente una Encuesta de Hogares; en esta ocasión 176 mil habitantes de 5 años y más en Barrancabermeja alcanzaron hasta nivel educativo primaria, es decir el $29.6 \%$, el $43.0 \%$ segundaria y el $24.8 \%$ restante niveles de educación superior. En esta misma medición, la tasa de analfabetismo para el municipio entre personas de 5 y más años es del $2.2 \%$. 
En la tasa desagregada por zonas se encuentra un porcentaje de $5.2 \%$ en zona rural y $1.9 \%$ en zona urbana. Cifras que varían mucho si se compara con base en la anterior encuesta.

Otro factor considerado como problemática del empleo se relaciona con la dependencia de las personas por vincularse en el sector petrolero, así lo señala Alba Luz Amaya representante de Ecopetrol en el Comité, quien además manifiesta: "son los sectores de servicio y comercio que desafortunadamente pagan mal y tienen incumplimiento en muchas ocasiones en los términos de ley del empleado y hace que haya una rotación gigantesca y pues no llene las expectativas de los trabajadores".

\section{Para Diana Estupiñán,}

Uno de los indicadores que nos llamó mucho la atención es el tiempo promedio que espera una persona para emplearse y en Barranca es más o menos de 9 meses para el caso de los hombres y en las mujeres es casi 12 meses, habría que hacerle la distinción de cuánto duran las personas que están desempleadas y que sólo quieren trabajar en el sector petrolero. (2014, 23 de septiembre. Entrevistado por Merlano, L., Barrancabermeja)

Finalmente, otra causa identificada es la falta de garantías para proteger la mano de obra local, los entrevistados aseguran que las normas y estrategias implementadas no han cambiado la situación, así lo argumenta Armando Vargas: "[...] las grietas siguen abiertas, esto permite a los que están por fuera de ellas hagan y deshagan y nosotros siempre llevamos la peor parte" (2014, 24 de septiembre. Entrevistado por Merlano, L., Barrancabermeja).

Una fuerte crítica se realizó al certificado de territorialidad (Decreto 080 de 4 de abril de 2013); las fallas señalan malos manejos por parte de la Alcaldía Municipal, "digamos no trasparente, y hemos tenido mucha falla en eso y nos 
preocupa porque la gente de afuera nos está invadiendo Barrancabermeja, no lo ven y no cumplen los requisitos que realmente exige el decreto", puntualizó Miguel Nieto, delegado de la Personería Municipal como veedor del Comité de Política Pública de Empleo de Barrancabermeja.

Como consigna de quienes representan a los trabajadores y la comunidad en general, las oportunidades deben priorizar a la gente del Puerto Petrolero: "aquella persona que venga tenga una oportunidad, pero primero están los nuestros", dijo Pedro Barrera (2014, 22 de septiembre. Entrevistado por Merlano, L., Barrancabermeja)

La problemática del empleo en la ciudad obedece entre muchos otros factores, a la falta de una política de desarrollo económico por fuera del enclave petrolero, para que se potencialicen otros renglones de la economía en las que se garanticen las condiciones laborales en materia salarial y prestacional de los barramejos. Existe una estigmatización con el oriundo del municipio, al considerarlo parte de la cultura contestaría. Desde esta mirada se complica la preferencia de la mano de obra local en los proyectos emergentes, generando altos índices de desempleo que en nada ayuda para la calidad de vida de sus pobladores.

Es necesario priorizar la educación como política pública para aumentar los niveles de escolaridad, de la mano con la generación de oportunidades laborales para propiciar un ambiente esperanzador en quienes se están formando. La gobernanza debe ser transparente y de cara a la sociedad, la falta de confianza entre los actores no vislumbra un panorama que avance hacia un desarrollo común y colectivo. 


\subsection{Surgimiento, contexto y actores que formularon la Política Pública de empleo en Barrancabermeja.}

Una de las causas del surgimiento de la Política Pública de Empleo es la intermediación de todo tipo de actores -incluso armados- en la adjudicación de empleos en la región, como lo asegura Angélica Suárez (representante de la Alcaldía Municipal):

...las juntas de acción comunal estaban ejerciendo intermediación laboral, iba y se presentaba ante el contratista y el contratista por quitárselo de encima le daba dos o tres cupos y ese líder comunal vendía los cupos, no sólo las juntas, también los grupos al margen de la ley hacían eso y cuanta asociación había hacían la misma intermediación, entonces obviamente acceder al empleo en Barrancabermeja se estaba volviendo un mercado negro. (2014, 18 de septiembre. Entrevistado por Merlano, L., Barrancabermeja)

Suárez señala que otro de los detonantes para que surgiera esta política tiene que ver con el asesinato del presidente de una JAC: "el punto culminante estuvo cuando se da el asesinato de un líder comunal, al que le decían "Cachetes", ahora no recuerdo el nombre, en el barrio (20 de enero, Ciudadela Pipatón) en la zona de la comuna 3" (2014, 18 de septiembre. Entrevistado por Merlano, L., Barrancabermeja).

Otra razón, fue el clamor de los ciudadanos de proteger la mano de obra local como una exigencia para garantizar el acceso a las fuentes de empleo en la ciudad y de organizar el tema.

...con el objeto de crear el Comité de Política Pública de Empleo para poder delimitar y hacer la trazabilidad de las políticas que se van a implantar en la ciudad con el objeto de propender y defender el recurso 
humano local. (Armando Vargas, 2014, 24 de septiembre. Entrevistado por Merlano, L., Barrancabermeja)

A raíz de que se quería buscar en Barrancabermeja una fórmula que permitiera dar solución al problema de empleo, a la mano de obra local, para ello se hicieron varios esfuerzos y se crearon decretos y leyes con el ánimo de poderle poner freno a esta problemática. (Pedro Barrera, 2014, 22 de septiembre. Entrevistado por Merlano, L., Barrancabermeja)

En ese mismo sentido, argumenta Alba Luz Amaya, representante de Ecopetrol en el Comité,

[...] esa política pública lo que hizo fue buscar la protección de la mano de obra local, tratar de cerrar las puertas de la ciudad a personas foráneas, con lo que no estamos de acuerdo en Ecopetrol en su totalidad, es decir creemos que indudablemente hay que proteger la mano de obra local, pero no es violando la constitución como se logra el mejoramiento de los indicadores de desempleo. (2014, 19 de septiembre. Entrevistado por Merlano, L., Barrancabermeja)

El surgimiento de la Política Pública de Empleo de Barrancabermeja se presenta en el año 2008 con el Acuerdo 005; sin embargo, la defensa de la mano de obra local se remonta muchos años atrás. Así lo constata Diana Estupiñán del CER:

...yo hice un rastreo de otras acciones o políticas públicas que se habían hecho frente al tema y hay un acuerdo de 1985 en donde se esboza la creación de un comité también para la protección de la mano de obra local, sin embargo, eso quedo ahí y fue a principios del gobierno anterior (Alcalde Carlos Contreras López 2008-2011) que se ve la necesidad ante las demandas de la sociedad civil, de pensar en qué hacer con el tema del empleo y aparece el Concejo Municipal con la creación del Acuerdo 005 y luego con la creación del Comité en el 2009. (2014, 23 de septiembre. Entrevistado por Merlano, L., Barrancabermeja) 
Una última razón que se expone es la necesidad de capacitar la mano de obra local, para certificar al personal por competencias y darle un valor agregado al talento humano con el que cuenta la ciudad. Angélica Suárez indica que:

...la persona que tiene mucha experiencia, basada en el hacer, entonces se le realizan unas pruebas técnicas y académicas escritas, si pasas esos dos exámenes, tiene que pasarlo con 100, se le certifica esa competencia laboral, eso es una lucha terrible, ya todo el mundo entendió que esto es un proceso muy complicado. (2014, 18 de septiembre. Entrevistado por Merlano, L., Barrancabermeja)

Tanto la intermediación, las capacitaciones y certificaciones por competencias están en cabeza del SENA, que es la entidad estatal delegada para tratar de evitar que estos problemas que manifiestan los miembros del Comité de la Política Pública de Empleo se presenten. Sin embargo, esta estrategia de selección a través del SENA tiene muchos detractores, que serán puestos en conocimiento dentro de este capítulo.

Por ahora, para seguir contextualizando la Política Pública de Empleo de Barrancabermeja, se mencionan las personas y entidades que permitieron y jalonaron esta iniciativa en el Puerto Petrolero. Algunas personas dan cuenta que esta PP surge en el Gobierno del Alcalde Municipal Carlos Alberto Contreras López (2008-2011), quien presenta el proyecto ante el Concejo Municipal y logra su aprobación para convertirse en el Acuerdo 005 de 2008. Angélica Suárez dice que fue vital el trabajo conjunto entre la Alcaldía Municipal y Ecopetrol; "también digamos con el concurso de entidades como el SENA, Fundesmag y el Centro de Estudios Regionales, estas son como las 5 entidades que se han unido para trabajar ese tema y bueno otros han ido llegando".

Darlinson Rendón, del SIGLA, relata que quienes impulsaron la política fueron "el Concejo Municipal, la Unión Sindical Obrera (USO subdirectiva 
Barrancabermeja), la Diócesis de Barrancabermeja, los gremios de empresarios de la ciudad, y muchos otros, son aproximadamente 22 instituciones que pensaron en una Barrancabermeja mejor y en eso estamos trabajando actualmente" (2014, 18 de septiembre. Entrevistado por Merlano, L., Barrancabermeja).

Pedro Barrera asegura ser una de las personas que impulsó esta iniciativa: "yo soy uno de los fundadores de la mesa pública de empleo, he estado en el gran acuerdo social, en ese tiempo el alcalde era el señor Carlos Contreras y el gobernador era Horacio Serpa de acuerdo a las necesidades se generó esa figura" (2014, 22 de septiembre. Entrevistado por Merlano, L., Barrancabermeja).

Un aporte distinto menciona Cristina Arenas, en representación de la Academia, quien señala: "nada en Barrancabermeja surge de la nada; todo es un proceso social del cual, los políticos y los gobernantes de turno, dan cuenta; en ese sentido, hubo voluntad de las partes y los sectores se han unido para impulsarla".

Algunos no conocen quienes impulsaron esta propuesta y lograron su materialización en Política Pública de Empleo Municipal. Como es el caso de Diana Estupiñán y Armando Vargas; éste último manifiesta: “...pues a ciencia cierta no tengo ese conocimiento y me gustaría conocerlo e ir más a fondo al respecto" (2014, 24 de septiembre. Entrevistado por Merlano, L., Barrancabermeja).

Cualquiera que sea el origen de la Política Pública de Empleo de la ciudad, lo cierto es que existe un clamor social por la defensa de la mano de obra local que deriva un trabajo constante de la sociedad civil, las organizaciones, las 
empresas y las instituciones para encontrar nuevas oportunidades laborales a sus comunidades.

\section{2. $\quad$ Definiciones de Defensa de la mano de obra local}

El componente de la defensa de la mano de obra local como un punto estratégico dentro de las acciones que persigue la Política Pública de empleo de la ciudad, fue una de las indagaciones de mayor interés por cuanto relaciona el tema de la ocupación y del desarrollo en Barrancabermeja, que está contenido en el Acuerdo Municipal 005 de 2008 que busca entre otras cosas, evitar la discriminación de la mano de obra local para generar oportunidades a las personas de la ciudad, de manera que esto traiga beneficios económicos y sociales, tal como se plantea existe mano de obra calificada y mano de obra no calificada en tanto las percepciones sobre este apartado se realizaron para saber qué se entiende por defensa de la mano de obra local, las estrategias implementadas para garantizar esa defensa, identificar si la política ha contribuido en esa defensa de la mano de obra local, si esto ha generado más oportunidades de empleo para la gente del territorio, entre otros interrogantes que surgieron en medio de la conversación, especialmente cuando se presentaron denuncias o quejas sobre la situación que viven los trabajadores y quienes los representan. A continuación se presentan apartes de los relatos.

Defender la mano de obra local para nosotros es que en igualdad de condiciones, es decir, si se presentan tres personas a un proceso de selección y en igualdad de condiciones esas tres personas todas sacan 90 puntos en el examen, pero sí de las tres hay un barranqueño que se prefiera el barranqueño, esa es la filosofía digamos de manera muy coloquial. (Angélica Suárez, 2014, 18 de septiembre. Entrevistado por Merlano, L., Barrancabermeja) 
Quien además agregó que lo anterior no generaría una migración adicional de gente a la ciudad, que luego demandaría servicios públicos, educación, transporte, vivienda, porque no viven allí... "esa es la filosofía, ¿para qué? Para no ocasionar más problemas sociales en la región". Por último reconoció que la preferencia de la mano de obra local debe basarse en las capacidades y el talento de la gente: "no es que me tiene que contratar porque soy de Barranca, de ninguna manera, si el personaje sacó 50 puntos en el examen, chao te vi y se lo ganó el de Bucaramanga, pero si están en igualdad de condiciones preferir al barranqueño" (2014, 18 de septiembre. Entrevistado por Merlano, L., Barrancabermeja).

Por otra parte, otros entrevistados piensan que la defensa de la mano de obra local significa:

...buscarle las oportunidades a los residentes locales de la ciudad, que como bien es cierto es la fuerza laboral económicamente activa de nuestra ciudad, somos los que movemos la economía local y somos los que generamos el desarrollo de la ciudad, pero si nos coartan ese espacio obviamente que no va haber ninguna ciudad futuro. (Armando Vargas, 2014, 24 de septiembre. Entrevistado por Merlano, L., Barrancabermeja)

Los significados se construyen desde lo social, en ese sentido, defender la mano de obra local, se constituye en la posición racional que asume la sociedad a partir de sus representantes, de dar pautas claras para que los empleadores asuman al ciudadano barranqueño como un sujeto capaz y competente para desempeñar una labor determinada y para ello, se crean estrategias de formación para la demanda y la oferta; buscando que no se discrimine al barranqueño por conocimiento o competencia; la defensa de la mano de obra local, se entiende como el derecho de ejercer la ciudadanía laboral en su localidad, Barrancabermeja. (Cristina Arenas, 2014, 23 de septiembre. Entrevistado por Merlano, L., Barrancabermeja)

Una percepción distinta es la que se explica desde la normatividad expedida. Algunos entrevistados no están de acuerdo con dar exclusividad a la mano de 
obra local; hay quienes demuestran su descontento y cuentan cómo les ha tocado organizarse para proteger el trabajo de su gente.

...la defensa de mano de obra local tiene ciertos requisitos para identificar cuáles son las personas que tienen sus arraigos con esta ciudad, la defensa de mano de obra local trata que estas personas sean las primeras opcionadas en acceder al empleo. (Adrián Rodríguez, 2014, 18 de septiembre. Entrevistado por Merlano, L., Barrancabermeja)

...la gente debe tener el perfil, cumplir con el perfil que se requiere para trabajar y si la cédula pues le ayuda, pues mejor, pero no quiere decir que sólo la cédula es la que genera o la que debe permitir el acceso a los contratos de Ecopetrol" y "así es como lo trató de hacer la política, la cédula por encima del conocimiento. No, lo que tenemos que hacer los barranqueños es prepararnos para que seamos nosotros con nuestro talento lo que hagamos respetar esa mano de obra. (Alba Luz Amaya, 2014, 19 de septiembre. Entrevistado por Merlano, L., Barrancabermeja)

Uno de los inconvenientes que se presenta respecto del componente defensa de la mano de obra local, es la necesidad que la política pública atienda otros aspectos para dar solución a la problemática de empleo de la ciudad y jalonar procesos de desarrollo distintos al de la industria. Es la percepción de Diana Estupiñán, del Centro de Estudios Regionales (CER):

Para mí el tema de la defensa de la mano de obra local es darle contentillo a unos pocos, como tratar con pañitos de agua tibia de calmar la cosa, entonces hay unas exigencias desde los sindicatos, desde las comunidades, etc.

También agregó:

El alcalde dice estamos construyendo una ciudad para el futuro, una ciudad región, pero por el otro lado evitan o ponen barreras de entrada a personas que puedan construir territorio conjunto así no hayan nacido acá, cierran las puertas. Una de las premisas básicas y la Constitución Política lo dice, la movilidad laboral es un derecho de todo 
el mundo (2014, 23 de septiembre. Entrevistado por Merlano, L., Barrancabermeja).

Concluyó con una recomendación:

Esa política pública debería de enfocarse a otro tipo de cosas, a cómo generar incentivos para que los jóvenes que vienen atrás empiecen a mirar otros sectores y empiecen a buscar empleos en unos lugares que no tengan que ser necesariamente el tema de Ecopetrol y el tema de la industria (2014, 23 de septiembre. Entrevistado por Merlano, L., Barrancabermeja).

Con lo anterior se muestra un panorama de percepciones diversas respecto del significado de la defensa de la mano de obra local, posiciones que se dan de acuerdo al papel de los entrevistados dentro del Comité de política pública. En términos generales se podría decir que la defensa de la mano de obra se evidencia cuando en la ciudad existe igualdad de condiciones en los procesos de selección, oportunidades laborales para las personas con arraigo en el territorio, reconocimiento de las capacidades de los barranqueños, espacios de formación para mejorar los conocimientos y habilidades, además de no discriminación, todo esto para ejercer el derecho a la ciudadanía de laborar en su propia localidad.

Con respecto a las estrategias implementadas para garantizar la mano de obra local, se evidencian algunas acciones emprendidas como la expedición del certificado de territorialidad (Decreto 220) que establece los vínculos de las personas con el territorio; la implementación de plataformas de servicio público de empleo a través del SENA y de CAFABA -aunque con respecto a este punto, como se puso de manifiesto anteriormente, estas dos acciones tienen detractores que denuncian el mal manejo del tema-; La concertación que se hace con las empresas que llegan a la ciudad para vincularlos con la política pública de manera que se tenga en cuenta la mano de obra local y se creen acuerdos de voluntades para dar cumplimiento a la política; la creación del 
Observatorio Laboral como herramienta con la que buscan conocer la dinámica de empleo para hacer seguimiento, que permitió contar con información del tema que antes no se tenía.

Finalmente, Alba Luz Amaya de Ecopetrol mencionó la formación del talento humano local:

...lo que buscamos realmente es que la calidad de la educación de Barrancabermeja mejore y creemos que la forma de generar empleo, desarrollo y crecimiento, progreso en general es a partir de la educación y eso es un ejercicio que estamos liderando todos con la unión de universidades y de algunas instituciones. (2014, 19 de septiembre. Entrevistado por Merlano, L., Barrancabermeja)

Pese a la identificación de las acciones anteriores, una de las quejas y denuncias más comunes, es el manejo que se le ha dado al certificado de territorialidad y a la falta de oportunidades laborales para los locales:

Se está garantizando a través de una serie de obstáculos que se denominan normas, decretos, resoluciones y como dicen hecha la norma hecha la trampa, pues obviamente para nosotros nos condicionan que tenemos que seguir unos lineamientos como por ejemplo el Decreto 2852, que tenemos que pasar por una plataforma pública de empleo, que tenemos que cumplir el 220 que es el certificado de territorialidad, en fin, en ese orden de ideas, hay una serie de obstáculos donde dicen que las intermediaciones laborales en Barrancabermeja son prohibidas, sin embargo, eso es el plato preferido en la ciudad. (Armando Vargas, 2014, 24 de septiembre. Entrevistado por Merlano, L., Barrancabermeja)

Es complejo decir que hay una garantía total de la mano de obra, hay una garantía parcial a través de los acuerdos que tiene la Alcaldía con Ecopetrol y con algunas empresas que de una $u$ otra forma han querido vincularse a este proyecto pero desafortunadamente en nuestro país hecha la norma, hecha la ley hecha la trampa y entonces todavía encontramos gente tramposa que de una u otra forma tratan de burlar los mecanismos que se tienen. (Jenaro Pedrozo, 2014, 24 de septiembre. Entrevistado por Merlano, L., Barrancabermeja) 
La Unión Sindical Obrera (USO) a través Ernesto Arias, uno de sus voceros, aseguró:

Nosotros hemos denunciado que ese documento (certificado de territorialidad) se está entregando también a la gente foránea, a la gente que no es de acá, consiguen sus amistades, consiguen sus palancas como dice uno acá y ellos por medio de esas personas consiguen ese documento. (2014, 20 de septiembre. Entrevistado por Merlano, L., Barrancabermeja)

Adicionalmente, agregó que esto puede generar problemas porque "los que somos de acá, conocemos quien es el foráneo, entonces a veces se da la tarea que la gente de acá persiga a la gente de afuera y empezar a preguntarle usted de dónde sacó el documento y eso se está poniendo riesgoso". Al respecto concluyó diciendo "acá no es que se le esté cerrando la puerta a ningún foráneo, aquí primero es la gente de la casa y con todo el respeto después todo el que viene de afuera" (Ernesto Arias, 2014, 24 de septiembre. Entrevistado por Merlano, L., Barrancabermeja).

Es importante aclarar que la USO no hace parte del Comité de Política Pública de Empleo en el momento de la entrevista; sin embargo, fue considerado dentro de los testimonios porque en sus inicios fue activo en su participación y porque el Secretario General y Representante de la Alcaldía consideró que era necesario que se escucharan todas las voces de quienes han formado parte del proceso y de la puesta en marcha de la política. Al respecto el vocero del sindicato petrolero, Ernesto Arias, explicó que debido a que las propuestas presentadas por el sindicato no eran tenidas en cuenta, la Junta Directiva Nacional de la USO decidió retirarse.

Durante las entrevistas surgieron algunas contra-preguntas, específicamente sobre el tema del manejo que se le está dando al certificado de territorialidad. 
Con base en los testimonios y quejas al respecto, se amplió esta información con Darlinson Rendón, uno de los profesionales delegados por el Comité y la Alcaldía municipal para generar su expedición:

Desafortunadamente en nuestra ciudad hay personas que se han dedicado a falsificar este documento, donde desafortunadamente para ellos es fácil detectarlos en cualquier filtro, ya sea en el momento que la Alcaldía le está haciendo un estudio a la nómina o sea la empresa contratista o la interventoría que lo esté validando, actualmente esos filtro están funcionando, se han detectado ya varios casos. Lamentamos por las personas que lo han hecho, pero se están haciendo acreedores a una denuncia penal por parte de la Administración Municipal, Ecopetrol o por la empresa que se los detecte por falsedad en documento público. (Darlinson Rendón, 2014, 18 de septiembre. Entrevistado por Merlano, L., Barrancabermeja)

Al respecto, a Armando Vargas y Miguel Nieto, quienes representan a las agremiaciones de trabajadores y a la comunidad civil en el Comité de la Política Pública de Empleo de Barrancabermeja respectivamente, se les contra-preguntó sobre los resultados que requieren de las mesas de trabajo y cómo les gustaría que se dieran las cosas con esta política:

Nosotros necesitamos más acciones tangibles, por ejemplo, que se vea el desarrollo y el bienestar, la mejora de la calidad de vida de cada uno de los ciudadanos", y agregó "muchas personas conocen un perfil, lo saben desarrollar, tienen sus actitudes y sus habilidades pero las oportunidades están como un eslabón perdido y ellos se refugian allí (mototaxismo o la piratería como actividad opcional) para poder subsistir. (Armando Vargas, (2014, 24 de septiembre. Entrevistado por Merlano, L., Barrancabermeja)

Fomentar empresa, que existan más oportunidades, pedirle al municipio y al gobierno nacional que nos colaboren en fomentar más empleo, más empresas, porque si no hay empresas no hay trabajo. (Miguel Nieto, 2014, 22 de septiembre. Entrevistado por Merlano, L., Barrancabermeja) 
En lo respectivo a si la política pública de empleo ha mejorado la defensa de la mano de obra local, si esto les ha traído oportunidades para acceder a un trabajo en el municipio, por lo general existe una actitud de conformidad, mientras que otros consideran que la PP no está dando más opciones a los barranqueños para vincularse y tener un empleo en el territorio. Desde los representantes de la institucionalidad la tendencia fue a resaltar lo que se ha avanzado y mejorado al respecto:

Si claro, afortunadamente hemos tenido un evidente ingreso de las personas a laborar con mayor frecuencia, anteriormente una persona entraba una vez al año y duraba tres o cuatro meses en refinería trabajando, porque no se defendía la mano de obra local, hoy en día esa misma persona entra 4, 5 y 6 veces a trabajar aquí en la ciudad, lo que si tenemos claro es que el empleo en la ciudad no ha sido suficiente para todos los barranqueños, desafortunadamente se evidenció la necesidad de otros fuentes de trabajo. (Darlinson Rendón, 2014, 18 de septiembre. Entrevistado por Merlano, L., Barrancabermeja)

Pero para los representantes de los trabajadores y la comunidad en general a través de las asociaciones, sindicato y hasta para la delegada del CER, la política pública no ha mejorado los niveles de empleo para las personas que están en capacidad de trabajar en el territorio:

El nivel de empleo no responde a la política pública, que haya más o menos empleo depende de acciones de las empresas, de acciones económicas y no de una política pública, es decir que haya protección de la mano de obra local no quiere decir que Ecopetrol vaya a generar mayor empleo, entonces yo creo que no. (Diana Estupiñán, 2014, 23 de septiembre. Entrevistado por Merlano, L., Barrancabermeja)

De pronto que haya mejorado los niveles no, que haya como más organización, lo que nosotros creemos que nos ha servido es en qué, en que la gente tenga como más amor por estar en la región, por estar en Barranca, por hacerse notar de que aquí hay gente capacitada, preparada, en eso ha ayudado mucho, en eso somos conscientes que le han dado a la gente como esa iniciativa que entre más yo esté entre 
los primeros pues voy a tener la oportunidad de ingresar. (Ernesto Arias, 2014, 20 de septiembre. Entrevistado por Merlano, L., Barrancabermeja)

Las acciones para garantizar la defensa de la mano de obra local en la política pública de empleo no llenan las expectativas de quienes hacen parte del Comité de Política Pública. Estas acciones han sido deslegitimadas por la falta de confianza. Esto se evidencia con las denuncias realizadas por algunos de los entrevistados, específicamente con respecto a la expedición del certificado de territorialidad y la plataforma pública de empleo del SENA, con las cuales los procesos pueden carecer de validez al ser señalados por su falta de transparencia, de acuerdo a las quejas que hacen los encargados de poner en marcha la política pública. En tal sentido, la PP está en mora de revisarse para ser ajustada y con esto avanzar con el propósito de generar un ambiente legítimo en su ruta por la generación de oportunidades laborales para el bienestar de los ciudadanos del puerto petrolero.

\subsection{La implementación de la Política Pública de empleo en Barrancabermeja}

Los entrevistados aseguran que la implementación de la PP "busca generar empleo en la ciudad, tratar de disminuir la tasa tan alta de desempleo" (Adrián Rodríguez, 2014, 18 de septiembre. Entrevistado por Merlano, L., Barrancabermeja). Para Alba Luz Amaya de Ecopetrol, "mejorar los indicadores, lo dice textualmente, no la defensa de la mano de obra local, yo creo que debería de ampliarse un poco en función del desarrollo o de la dinamización de la economía, que es lo que generaría más empleo" (2014, 19 de septiembre. Entrevistado por Merlano, L., Barrancabermeja).

Para Darlinson Rendón, la política busca: 
...mayores ingresos para nuestras personas, desarrollo local, que la inversión crezca en la ciudad, que los habitantes tengan un mayor poder adquisitivo, que los proyectos que se ejecuten en la ciudad sean hechos en su mayoría por mano de obra barranqueña [...] que haya participación, que haya mejor calidad de vida y que sean vinculadas nuestras personas que están formadas y capacitadas para ejercer estas labores. (2014, 18 de septiembre. Entrevistado por Merlano, L., Barrancabermeja).

Por su parte Jenaro Pedroso pide "[...] que al barranqueño no se le estigmatice, que el barranqueño tenga la oportunidad laboral, que las mujeres barranqueñas cabezas de familia puedan tener acceso a un puesto laboral" (2014, 24 de septiembre. Entrevistado por Merlano, L., Barrancabermeja).

Otro aporte que complementa lo anterior es hecho por Cristina Arenas, de la Academia, quien indica que:

se busca que haya convivencia pacífica, que la comunidad tenga los recursos para una mejor calidad de vida; se busca ofrecer a todos los barranqueños nativos o a quienes cumplan con este título, la garantía que frente a los empresarios, se respetan sus derechos; se busca además generar una cultura del trabajo en los distintos sectores para que las personas rompan el paradigma del salario petrolero por dos 0 tres meses y lograr el de un salario digno, con prestaciones y probablemente indefinido. (2014, 23 de septiembre. Entrevistado por Merlano, L., Barrancabermeja)

Posiciones encontradas son presentadas por Diana Estupiñán del CER y Armando Vargas, quienes indican que la política pública de empleo busca:

Claramente defender el empleo de Ecopetrol, porque ese es el empleo de la ciudad, defender la mano de obra para que pueda acceder al mercado de trabajo de Ecopetrol. La política de empleo no busca mejorar las condiciones de la ciudad, busca mejorar el acceso al empleo a un grupo de personas que quieren acceder a la industria 
petrolera. (Diana Estupiñán, 2014, 23 de septiembre. Entrevistado por Merlano, L., Barrancabermeja)

...la idea es mejorar la calidad de vida de todos los ciudadanos de Barrancabermeja, pero eso está dentro de un contexto de la letra muerta por que si nosotros nos salimos de allí y vamos, obtenemos las experiencias y las vivencias cotidianas que viven día a día cada ciudadano, eso no está pasando,(Armando Vargas, 2014, 24 de septiembre. Entrevistado por Merlano, L., Barrancabermeja)

Para la Secretaria Privada y representante de la Alcaldía Municipal, se buscan tres cosas: la primera capacitar el talento humano local, la segunda fortalecer la dinámica económica de la ciudad y la tercera calidad en todos los procesos que se desarrollen en Barranca.

En cuanto a las percepciones relacionadas con la puesta en marcha de la Política Pública de Empleo de Barrancabermeja, en términos generales las opiniones son variadas; sin embargo, para la mayoría la implementación ha sido regular y/o aceptable. Cristina Arenas, representante del sector académico de la ciudad dice que "hace falta seguimiento por parte de los subcomités de la política... es un proceso que lleva cerca de cinco o seis años y por tanto, aún tiene mucho que desarrollar y desaprender" (2014, 23 de septiembre. Entrevistado por Merlano, L., Barrancabermeja). Mientras que para otros miembros del Comité no se han cumplido las expectativas: "Hasta la presente yo la veo como regular, porque no se ha dado lo que nosotros estábamos esperando, están teniendo en cuenta a la gente de afuera y aquí en Barrancabermeja se han visto ya espejos", aseguró Miguel Nieto (2014, 22 de septiembre. Entrevistado por Merlano, L., Barrancabermeja). Por su parte Adrián Rodríguez señala:

No ha tenido todo el alcance que uno pudiese esperar, con el agravante de que no tenemos una política de desarrollo económico de la ciudad, que debería integrase; deberíamos tener una sola política 
que contemple temas de generación de empleo, emprendimiento, de desarrollo económico, eso debería ser una sola política de empleo...ha sido un desempeño aceptable con lo que hay, pero nos falta proyectarnos más. (2014, 18 de septiembre. Entrevistado por Merlano, L., Barrancabermeja)

Algunos de los entrevistados no asignaron una evaluación a la puesta en macha de la Política Pública de Empleo del Puerto Petrolero, dentro del rango sugerido (buena, regular o mala). Como es el caso de Alba Luz Amaya de Ecopetrol quien dice que la implementación ha resultado lenta y difícil porque las personas no la han aceptado:

...nosotros estuvimos un año distribuidos por equipos dando a conocer lo que estamos haciendo y hubo una comuna donde nos sacaron amenazados, tuvimos que llamar a la policía, porque para la gente la política es sólo en función de Ecopetrol... La verdad es que hay gente de afuera trabajando en Ecopetrol, hay, habrá y tiene que haber, la política pública de empleo no es para sacar corriendo a la gente que viene de afuera, no toda la gente de la ciudad tienen los perfiles que la empresa... hemos invertido más de $\$ 8.000$ millones en eso, lo estamos haciendo con la confianza, con la seguridad y con el compromiso que el empleo deber ser para la gente local preferiblemente, eso lo tenemos clarísimo, pero tenemos que modificar muchas cosas en preparación y sobre todo en comportamiento y en actitud, de la gente frente a su desempeño laboral. (Alba Luz Amaya, 2014, 19 de septiembre. Entrevistado por Merlano, L., Barrancabermeja)

Por su parte, Darlinson Rendón del SIGLA reconoce que la puesta en marcha de la Política Pública de Empleo en la ciudad ha sido difícil porque asegura en el territorio aún persisten grupos al margen de la ley:

...hemos encontrado muchos actores que han dificultado la puesta en marcha en algunos sitios, como lo son los corregimientos donde actualmente existen grupos al margen de la ley manejando el tema de empleo, llevar la política pública, y el servicio público de empleo a esos sitios ha sido bastante difícil. (2014, 18 de septiembre. Entrevistado por Merlano, L., Barrancabermeja) 
Otras personas son más optimistas frente a la implementación desarrollada para la Política Pública, porque aunque hace falta mucho camino por recorrer, la ciudad fue pionera en la puesta en marcha de lineamientos para combatir la intermediación y defender la mano de obra local en economías extractivas como la refinación del petróleo:

...el alcalde Elkin Bueno quiere dejarla implementada como una política pública de tal manera que indistintamente del gobernante que llegue, haya unos parámetros, unos lineamientos que sea obligatorio cumplir y creo que eso es importante, (Angélica Suárez, 2014, 18 de septiembre. Entrevistado por Merlano, L., Barrancabermeja)

...al principio fue muy mala porque la gente no entendía qué era una mesa pública de empleo, cuál era el objetivo y hacia dónde iba. Hubo contradictores pero gracias a Dios, con el trascurrir del tiempo, han entendido tanto los empresarios como los empleados que es una herramienta buena para todos, tanto al señor que viene a contratar como a la mano de obra que hay. (Pedro Barrera, 2014, 22 de septiembre. Entrevistado por Merlano, L., Barrancabermeja)

Para Diana Estupiñán del CER, la Política Pública desde su formulación tiene problemas. Sin embargo, ha sido buena por el esfuerzo de los actores (principalmente menciona al SENA, Ecopetrol y a la Alcaldía), que han encaminado acciones para monitorear la dinámica laboral, que anteriormente no contaban con una línea de base. Por medio del Observatorio Laboral pueden tener una visión de la ciudad frente al tema del empleo, que no sólo da cuenta de la protección a la mano de obra local, también reconoce que los resultados no son los esperados pero se han buscado los mecanismos para seguir firmes con el compromiso "...entonces yo siento que si ha sido muy bueno la puesta en marcha de la política, aunque siento que la política no responde al problema, pero lo que se ha hecho ha sido muy bueno, a la luz de lo que se decidió hacer" (2014, 23 de septiembre. Entrevistado por Merlano, L., Barrancabermeja). 
La percepción de Armando Vargas sobre la puesta en marcha de la política pública de empleo en Barrancabermeja es que ésta no pasó la prueba. Para él, la implementación ha sido mala porque no está dando los resultados y en ese caso el Comité debe ser cambiado, rotar y renovarse por no generar acciones y medidas que propendan por la calidad de vida de las personas de la ciudad:

...simplemente se están es eternizando allí, si esas ideas que están allí en 5 años que es un tiempo suficiente no lograron hacer nada, hay que hacerse a un lado y darle la oportunidad a las nuevas generaciones $u$ otra series de mentes que tengan otras ideas más positivas. (2014, 2\$ de septiembre. Entrevistado por Merlano, L., Barrancabermeja)

Al referirse a la etapa de implementación, se habla de acciones a desarrollar para la materialización de la Política Pública. Sin embargo, en este caso muchos de los componentes no se han desarrollado, así lo asegura Adrián Rodríguez, Coordinador de esta mesa de trabajo:

...la política de empleo del Acuerdo 005 tiene alrededor de 15 componentes, actualmente estamos trabajando con la preferencia de la mano de obra local, se habla de un sistema georeferenciado para identificar cuáles son las comunas en las que hay mayor desempleo... otro componente es aquel que habla de incentivos tributarios para la población vulnerable, algo se ha trabajado de eso. (2014, 18 de septiembre. Entrevistado por Merlano, L., Barrancabermeja)

Rodríguez, agrega que esto se debe a "la calidad del Comité de Política Pública que se ha convertido en un comité de quejas y reclamos, y el interés de ese comité se ha desviado hacia simplemente verificar y defender la obra de mano local y no se ha mirado más allá". Finaliza asegurando que es necesario desarrollar otros componentes del Acuerdo Municipal para avanzar en la Política Pública: 
La política pública tiene otros componentes que debemos desarrollar, ese comité tiene que hacer sugerencias, ya que es un comité técnico no sólo ser un comité donde se lleven quejas y reclamos sobre la plataforma de empleo o sobre la defensa de mano de obra local, se deben generar las otras estrategias que están contempladas en ese Acuerdo. (2014, 18 de septiembre. Entrevistado por Merlano, L., Barrancabermeja)

Una de las acciones ejecutadas en la Política Pública de Empleo de la ciudad es el Decreto 220 del 7 de octubre de 2013 -con el que se derogó al anterior Decreto 080 del 4 de abril de 2013-, por medio del cual se estableció el procedimiento para expedir el certificado de territorialidad para acreditar la residencia en el municipio de Barrancabermeja, con el que se pretende proteger la mano de obra calificada y no calificada del Puerto Petrolero de acuerdo a las demandas que ha exigido la sociedad porteña desde 1985. Esta es una de las acciones más destacadas por los entrevistados.

...se buscó darle un documento que permita identificar al trabajador barranqueño, bastando que su cédula fuera del municipio o hubiese nacido en Barrancabermeja y las otras personas que han vivido o que han venido, caso específico como el mío que tenemos 60 años o más de vivir en barranca, que nuestros hijos son barranqueños y han estudiado aquí he inclusive unos también han estudiado acá, se le acredite o se le adopte como barranqueño. (Jenaro Pedroso Sánchez, 2014, 24 de septiembre. Entrevistado por Merlano, L., Barrancabermeja)

...la creación del decreto de territorialidad, que tampoco es la solución, pero que ha servido. El decreto no es para trabajar, el decreto es para identificar las personas que tienen vínculo con la ciudad y Ecopetrol ha articulado su trabajo en Barrancabermeja en función de esa exigencia del municipio. (Alba Luz Amaya, 2014, 19 de septiembre. Entrevistado por Merlano, L., Barrancabermeja)

Otra acción es el acuerdo de voluntades con el que se busca que las empresas que lleguen a la ciudad, especialmente las que trabajan la extracción o refinación del petróleo, contraten el $80 \%$ de mano de obra calificada y no 
calificada. El 20\% restante puede ser mano de obra foránea, así lo indicó Pedro Barrera en representación de las JAL:

...Ecopetrol cuando va a firmar con la persona el contrato le dice aquí hay un acuerdo municipal que dice que el $80 \%$ tiene que ser gente local y el $20 \%$ puede ser foránea, bajo esos acuerdos es que firman el contrato, sin embargo, hay empresas que han sido muy solidarias y contratan el $100 \%$ de personal local, ósea si ha dado resultado de acuerdo a las voluntades y a la mano de obra que hemos capacitado. (2014, 22 de septiembre. Entrevistado por Merlano, L., Barrancabermeja)

Al respecto de ese acuerdo de voluntades, para Ecopetrol es un anexo contractual, según lo asegura su representante en el Comité:

Se firman para su ejecución en Barrancabermeja y busca mecanismos que permiten que la ciudad esté informada sobre el empleo que se genera, nosotros estamos haciendo cosas que no está haciendo nadie en el país, sin ninguna modestia creo que nosotros podemos decirle al Ministerio que es acá, que es con base en los resultados del trabajo de aquí, que el Ministerio genera la nueva política nacional. (Alba Luz Amaya, 2014, 19 de septiembre. Entrevistado por Merlano, L., Barrancabermeja)

Aunque este acuerdo de voluntades, como lo han denominado, no obliga a las empresas a realizarlo, el Comité de la Política Pública por medio de la socialización ha vinculado a otros contratistas para que participen de esta propuesta local. Así lo manifiesta Darlinson Rendón del SIGLA:

Nuestro señor Alcalde ha estado presente en las empresas que han llegado a la ciudad, que están desarrollando proyectos de alto impacto, donde estas empresas se han comprometido con la ciudad, como el proyecto de construcción del puerto IMPALA Barrancabermeja, en este momento estamos trabajando un acuerdo de voluntades que consta que ellos se acogen a la política pública de empleo y se comprometerían a llevar su porcentaje de mano de obra local hasta el $80 \%$ entre la mano de obra calificada y o calificada. (2014, 18 de septiembre. Entrevistado por Merlano, L., Barrancabermeja) 
Dentro del proceso de implementación también se han desarrollado procesos de formación, resaltó Angélica Suárez, Secretaria Privada de la Alcaldía Municipal, con lo cual Barrancabermeja es modelo a nivel nacional en temas como la certificación por competencias, los procesos de formación para el trabajo y el de formación humana que es liderado por la Diócesis Municipal. Por otra parte la funcionaria mencionó que ahora a las personas interesadas se les brinda orientación laboral a través de las agencias públicas de empleo: "a veces la gente, llega siempre pensando en que, bueno tengo que trabajar en esto, pero en la agencia le pueden decir, no vea su perfil da más para este lado, entonces la orientación laboral también es importante, en eso también estamos fuertes" (2014, 18 de septiembre. Entrevistado por Merlano, L., Barrancabermeja).

Otra acción es la socialización que se le ha dado a la Política Pública, es decir, que a cada empresa contratista que llega a la ciudad para el sector petrolero se le comunica de la existencia de la misma para hacerlos participes en lo que se viene trabajando y los beneficios que pueden recibir. Así lo aseguró Diana Estupiñán del CER:

...digamos que las acciones del comité han sido como venga, llamar a la gente, como venga conozca y empecemos a trabajar conjuntamente por la ciudad. Me parece que ese ha sido un mecanismo exitoso en el sentido que las empresas conocen. Ya digamos si cumplen o no, depende es de los lideres, es decir los lideres le hacen presión a Ecopetrol, pero no le hacen presión a otros sectores a pesar de que los llaman, es decir, que el comité está haciendo su trabajo de socializar y entonces los veedores dónde están, si son las empresas que deciden, por voluntad propia, no porque sea una obligación hacerlo, dónde están los veedores de otros sectores que no sean los de Ecopetrol. (2014, 23 de septiembre. Entrevistado por Merlano, L., Barrancabermeja)

En ese mismo sentido, la información se ha convertido en una fortaleza; así lo señala Alba Luz Amaya de Ecopetrol, quien reconoce que antes era una 
falencia y ahora son ejemplo en el Magdalena Medio porque han logrado "la creación del observatorio del mercado laboral, han obtenido la recopilación de información y el diseño de una línea base para poder trabajar un camino que permita identificar resultados a largo plazo" (2014, 19 de septiembre. Entrevistado por Merlano, L., Barrancabermeja).

Por unanimidad, una acción importante fue a la creación de una nueva agencia pública de empleo liderada por la Caja de Compensación Familiar de Barrancabermeja (Cafaba). Sin embargo, para quienes representan a la sociedad civil o a los trabajadores en el Comité de Política Pública de Empleo, ésta no satisface las expectativas:

...el desarrollo del servicio público de empleo termina siendo un negocio para las mismas empresas, me explico, el tema es que quien tenía el monopolio venía dándole las claves de acceso de la plataforma a los contratistas, no pudiera probar, si por plata o por cuestiones políticas del mismo SENA, pero lo que si es cierto es que ellos terminaban postulando y escogiendo el mismo personal que la misma empresa quería. Nosotros como organización terminamos denunciando, eso hace que la Alcaldía a través del alcalde de turno, crea un nuevo servicio público de empleo (CAFABA), nos vincula como organización, no solo a los sindicatos sino también a parte de la comunidad y es donde entran a jugar todos los representantes de cada una de las especialidades, en ese punto es donde logramos de alguna manera frenar un poco, aunque se pudiera decir que está funcionando o ha empezado el desarrollo de este servicio público de empleo, aún falta mucho por mejorar. (Ignacio Vecino. 2014, 20 de septiembre. Entrevistado por Merlano, L., Barrancabermeja)

La estrategia más criticada fue la plataforma implementada a través del Servicio Público de Empleo del SENA. Sin embargo, está se desarrolla en un apartado más adelante porque amerita un abordaje del tema.

Finalmente, sobre las acciones implementadas por el Comité en cumplimiento de la Política Pública de Empleo municipal, Cristina Arenas 
Sepúlveda representante de Centros de Investigación y Universidades de la ciudad, destacó:

...el apoyo de la empresa Ecopetrol, a mi juicio, ha sido importante, ha marcado una pauta para 'obligar' a las contratistas a respetar; con el apoyo de la compañía se ha logrado construir el Observatorio Laboral, desarrollar censos, capacitar a la población, entrar en un diálogo con el alto gobierno, con el SENA y así, poco a poco, ir convenciendo a los empresarios de no hacerle trampa a la plataforma; de ser más públicos; es un proceso que lleva cerca de cinco o seis años y por tanto, aún tiene mucho que desarrollar y desaprender. (2014, 23 de septiembre. Entrevistado por Merlano, L., Barrancabermeja)

La implementación de la política pública no ha sido lo que esperaban quienes hacen parte del Comité; la mayoría no tiene claridad sobre los objetivos y las apuestas de la PP. Además, las estrategias propuestas para defender la mano de obra local siguen siendo deficientes y no resuelven el problema del desempleo en el municipio. Efectivamente se evidencia que la puesta en marcha ha sido compleja, pero eso se agrava al no existir un trabajo coordinado para sacar adelante las acciones planteadas. La lucha por los intereses de los actores del Comité da cuenta de las dificultades y no se han dejado a un lado las diferencias para trabajar por el sendero trazado en la política.

7.3.1. Aciertos, desaciertos y retos que enfrenta la Política Pública de empleo en Barrancabermeja

Resulta importante para este trabajo de investigación establecer los logros, desaciertos y retos que enfrenta la política pública de empleo del municipio de Barrancabermeja, desde la óptica de quienes hacen parte del comité que trabaja por promocionarla e impulsarla. Para esto se realizó la tabla 4 incluida en los 
anexos. Allí se contrastan las percepciones de los entrevistados, de acuerdo, al análisis realizado.

Los resultados señalan que a la política pública de empleo de la ciudad se le reconocen algunos logros, como la generación de acuerdos de voluntades con algunas de las empresas que han llegado al territorio para que se de preferencia a la mano de obra local, la consolidación de información sobre la situación de empleo de la ciudad a través del Observatorio de Mercado Laboral para hacer seguimiento y permitir la toma de decisiones al respecto, el impulso a la formación del talento humano para tener personal capacitado, el fortalecimiento como una visión conjunta del territorio el respeto por la mano de obra local, la posibilidad de vislumbrar la búsqueda de otras actividades diferentes a la extracción petrolera como una alternativas para encontrar en otros recursos del territorio el bienestar social, el rechazo a la intermediación laboral indebida y la creación de plataformas públicas para procurar procesos de selección equitativos. Sin embargo, es recomendable tener en cuenta las principales desventajas o desaciertos cometidos con la política pública para establecer acciones de mejora o cambio para sus resultados.

Se evidencia la falta de un alcance que no limite la PP exclusivamente a la defensa de la mano de obra local, sino que la potencie hacia la consolidación de una PP que genere desarrollo local a través del empleo; La PP debe trascender a la generación de empleos que resulten de la Refinería de Ecopetrol y dar prioridad a otras actividades productivas y económicas que pueden generar más opciones a quienes buscan un empleo en la ciudad; La PP no ha logrado atraer a los empresarios para vincularse y comprometerse en la implementación de la política; La cultura de la ilegalidad como una opción de vida ha generado inconvenientes para que la puesta en marcha de la PP tenga los resultados esperados; no se han generados los empleos suficientes para garantizar la 
ocupación de las personas que se han capacitado y formado con la esperanza de encontrar un empleo; La deslegitimación de algunas acciones emprendidas por la política ha generado desconfianza entre los diversos actores.

La apuesta implica un reto muy grande para la PP, porque ésta debe generar oportunidades para todos, sean locales o personas que encuentran en el territorio un espacio para establecerse. Es necesario actualizar la PP a la realidad social y económica, y con esto crear herramientas para un modelo de desarrollo local que responda las expectativas de las comunidades sino habrá fracasado la formulación de la política. Es imprescindible bajar los niveles de desempleo diversificando la economía, apostándole a otros renglones productivos para que las personas construyan un proyecto de vida entorno a mejores oportunidades laborales que les permitan ampliar sus capacidades. Generar estrategias o acciones para vincular a todos los empresarios en la consolidación de una PP clara, coherente y que presente resultados. La PP debe trazar lineamientos de empleos dignos y decentes para la población barrameja, en donde encuentren condiciones laborales que mejoren sus expectativas de vida. La sociedad debe rodear la PP, defenderla, construirla, implementarla, hacerle seguimiento, mejorarla y evaluarla, para vincular más sectores y actores que piensen el desarrollo que todos anhelan para la ciudad con una apuesta y visión compartida.

Dentro de las indagaciones, se encontró que varios actores plantean críticas a la política pública de empleo, es preciso recordar, para que una política pública tenga viabilidad es importante involucrar a los diferentes actores en cada uno de los procesos; con esto se está garantizando en buena medida la participación activa y la construcción colectiva en la solución de los conflictos de esa misma comunidad. Para este caso, es preciso mencionar que la PP dio lugar a desencuentros, incluso, algunos miembros del Comité entrevistados manifiestan críticas e inconformidades al respecto. En este sentido, vale la pena preguntarse 
si la política responde a la dinámica laboral del territorio y si cumplió los pasos para ser impulsada desde la sociedad de manera que atienda la problemática social que los afecta.

Es importante que la comunidad entienda, que la política pública de empleo no es para coger del pelo a la gente que no es de Barranca y sacarla a rastra de la ciudad, ese no es el propósito y eso es lo que la gente quiere que nosotros hagamos y eso es lo que se ha tratado de hacer, lo que tenemos que buscar es mecanismos que permitan que la gente tenga ocupación productiva y no necesariamente esa ocupación tiene que ser al interior de Ecopetrol, porque la Refinería no consume la cantidad de gente que hay desocupada y en eso tenemos que tener conciencia. (Alba Luz Amaya, 2014, 19 de septiembre. Entrevistado por Merlano, L., Barrancabermeja)

Sin lugar a dudas los altos niveles de desempleo que se registran en la ciudad, el nivel de formación académica no superior y la búsqueda de empleo en las mismas fuentes han generado esa resistencia. Para Armando Vargas esto se debe a que las personas conocen los desaciertos y a que los avances no corresponden a la realidad, "esto obliga a que la clase obrera salga a protestar para exigir que se corrijan esa serie de flagelos que no lo dejan a uno surgir y buscar el desarrollo de la ciudad" (2014, 24 de septiembre. Entrevistado por Merlano, L., Barrancabermeja).

Para otros miembros del Comité, muchas personas se niegan a reconocer que las cosas están mejorando porque la PP no está definida para garantizar o ampliar el empleo en la Refinería de Ecopetrol: "el empleo de la refinería es el que necesita la refinería punto, es decir más empleo no va a haber, es hacia dónde debo mirar yo y hacia dónde debo buscar empleo", (Diana Estupiñán, 2014, 23 de septiembre. Entrevistado por Merlano, L., Barrancabermeja) 
Algunos consideran que las protestas y la inconformidad con respecto a la política pública de empleo obedecen a un tema cultural y contestatario de las comunidades barramejas:

Aquí en barranca nosotros somos muy culturales en la protesta a raíz de la USO es algo que tenemos en la sangre y nosotros donde estemos en Colombia nos dicen sindicalistas porque nosotros no tapamos nada somos abiertos y les decimos las verdades al que sea y como sea. (Pedro Barrera, 2014, 22 de septiembre. Entrevistado por Merlano, L., Barrancabermeja)

Otras percepciones que están relacionadas con los resultados consideran que no son los que esperaban; aseguran que no se le ha dado un buen manejo por parte de la Alcaldía Municipal, especialmente con la expedición de los certificados de territorialidad, la defensa férrea de la mano de obra local y la generación de más capacitaciones. Algunos se atrevieron a argumentar que el inconformismo es debido a que se le quitó el negocio a quienes se lucraban con la intermediación:

Desafortunadamente si tenemos personas que no están de acuerdo con la política, por un lado están las personas que ejercen sus actividades que son contrarias a la política y que ajustarse a la política sería dejar su actividad económica, existen otras personas que son contrarias a la política porque no desean formarse, porque no desean ser regulados. (Darlinson Rendón, 2014, 18 de septiembre. Entrevistado por Merlano, L., Barrancabermeja)

Siempre vamos a contar con personas que no están conformes con lo que sucede y no tanto con la política sino contra aquellos que le hacen la jugada a la política, trayendo gente de otro lado después de haber colocado unos perfiles inalcanzables para poder responder a los que ya tienen contratados de otro lugar; eso lo evidencian algunas organizaciones y ponen la queja. (Cristina Arena, 2014, 23 de septiembre. Entrevistado por Merlano, L., Barrancabermeja)

La resistencia u oposición a la PP evidencia una falta de resultados concretos a los problemas que demanda la comunidad, su gerenciamiento vertical, en 
donde aun contando con la participación de algunos sectores no se trabaja coordinadamente para encontrar alternativas que permitan generar empleo, en el que se defienda la mano de obra local en el territorio. La construcción colectiva de la PP permite que sus acciones tengan mejor recepción y efectividad durante la implementación; lo contrario generará más dificultad para la materialización de los resultados.

7.3.2. Cambios o modificaciones para realizar en la Política Pública de empleo en Barrancabermeja

De acuerdo con el planteamiento de Ordoñez (2013), quien recomienda prever algunos cambios que se puedan presentar para mejorar la política pública durante la implementación, todos los entrevistados estuvieron de acuerdo en que es necesario modificar algunos de los planteamientos de la PP. Sobre esto, los relatos dan cuenta de la necesidad de actualizar la política, ajustar la parte normativa y fortalecer la formación de las personas:

Ya Barrancabermeja no es un anclaje petrolero nuestra economía se está diversificando, entonces debemos actualizar esta política; no solo enfocarla en la mano de obra local sino tener una verdadera política de desarrollo económico en la ciudad. (Adrián Rodríguez, 2014, 18 de septiembre. Entrevistado por Merlano, L., Barrancabermeja)

Recomendaría hacerle un ajuste a la parte normativa, la parte de la constitución y sus estatutos o al reglamento interno de ese comité de política pública de empleo, como también rotar la gente, rotarla para darle oportunidad a mentes frescas y con ideas nuevas de querer mejorar, porque uno está haciendo recomendaciones. (Armando Vargas, 2014, 24 de septiembre. Entrevistado por Merlano, L., Barrancabermeja)

También manifiestan que es necesario cambiar o rotar a los integrantes del Comité para que aporten nuevas ideas que ayuden a impulsar la política; 
consideran que deben incluirse nuevos sectores que operen los subcomités y que los representantes sean convocados con mayor asiduidad, además, movilizándose para realizar seguimiento; fortalecer la comunicación y la cultura ciudadana para evitar la agresividad, la ilegalidad y la violencia que se generan en torno al empleo; implementar una veeduría y una oficina de servicio al cliente para que la comunidad realice quejas y reclamos con el ánimo de atenderlas para buscar mejoras.

Algunos mencionaron la necesidad de "que la gente hiciera parte, se comprometieran realmente, se pusieran la mano en el corazón y le diéramos la oportunidad real a todos los barranqueños", con especial atención a los jóvenes, a las personas mayores de 50 años y a los discapacitados. Se indicó que es necesario hacer una planeación a futuro de la política pública para tener un rendimiento que llegue al 100\%. Finalmente, Diana Estupiñán del CER manifestó que es necesario reformular toda la política para que responda al tema del empleo de la ciudad.

Es preciso recordar que el proceso de implementación de una PP es difícil. En este sentido, cuando los resultados no cumplen lo planteado es indispensable replantear la política; es aquí cuando se puede pensar en un rediseño para adaptar el proceso al entorno social, económico y político que se esté presentando. Con esto se busca encontrar las soluciones para avanzar en la consecución de los resultados; de una u otra forma es aprender haciendo, como lo argumenta Ordoñez (2013 p. 220), para no deteriorar los resultados de la PP. Ahora el reto es minimizar los errores para salir adelante con las modificaciones que se concierten. 
7.3.3. El desarrollo local a través de la implementación de la Política Pública de empleo en Barrancabermeja

Son más de seis años desde que se puso en marcha la política pública de empleo de Barrancabermeja; es oportuno establecer cuál ha sido el aporte que ésta ha generado al desarrollo local de la ciudad. En este sentido algunos de los miembros del Comité consideran que con la implementación de la política se ha contribuido en disminuir en "algo" los niveles de desempleo; ha logrado un orden para controlar el "caos" entorno a la protección de la mano de obra local y que con estos salarios reinvertidos en la ciudad se brindan condiciones que mejoran la calidad de vida de los barranqueños. Por el contrario otros consideran que la PP no ha generado desarrollo local porque el nivel de desempleo es alto.

Según Cristina Arena Sepúlveda, la Política pública de empleo "ha generado un proceso de reflexión al interior de las empresas, ha generado transformaciones en las maneras de actuar de los empleadores $y$ ha organizado a los ciudadanos en torno a unas dinámicas diferentes a la malla y aunque siguen estando en ella, ahora visitan la red con mayor frecuencia generando otros lenguajes y subjetividades".

Por su parte para la Secretaría Privada de la Alcaldía Municipal, Angélica Suárez, la política aporta al desarrollo desde todo punto de vista:

En la medida en que hay ciudadanos que se favorecen de ella logrando un empleo digno, eso se refleja en la dinámica económica de la ciudad, en la medida que nosotros logremos que disminuya el índice de desempleo en Barrancabermeja, eso se va a reflejar en la dinámica económica de la ciudad, en la medida que logremos que disminuya la migración de gente hacia Barrancabermeja, buscando un empleo y quedándose aquí vamos a lograr favorecer el desarrollo de la ciudad. 
(2014, 18 de septiembre. Entrevistado por Merlano, L., Barrancabermeja)

Mientras que otras personas del Comité consideran que la política pública no contribuye al desarrollo local porque según ellos las cifras del desempleo hablan por sí solas: "Cada día vemos personas que claman una oportunidad laboral y no la encuentran, los pocos que la encuentran ganan unos salarios paupérrimos, muy deficientes que a veces pasan por encima de los estándares o las normativas de la parte laboral que son los salarios" (Armando Vargas, 2014, 24 de septiembre. Entrevistado por Merlano, L., Barrancabermeja). Por esta misma línea se ubica el Sindicato de la USO, quienes creen que la política está enfocada a recoger la mano de obra local que se requiere en el momento pero no tiene una visión más allá para generar oportunidades en otras actividades y oficios que se generan en el territorio. Otra visión relató Diana Estupiñán, quien señaló:

Pues es que depende del tipo de concepto que uno tenga de desarrollo, si hablamos del enfoque sobre desarrollo endógeno yo diría que posiblemente sí, porque el desarrollo endógeno tiende a que las capacidades se generen en el territorio y después se amplíen, pero si uno habla de desarrollo en general uno diría que no... si uno piensa en capital humano el desarrollo requiere de mayores niveles de educación de los trabajadores para generar innovación, para generar nuevas tecnologías y para desarrollar el territorio, es decir cómo le apunta la política a esa nueva generación de conocimiento que en ultimas es lo que aporta esas herramientas para que se pueda desarrollar un territorio... nosotros no estamos pensando en el desarrollo, estamos pensando en bienes individuales, en cómo logro yo poder acceder a mayores recursos, yo, pero la ciudad, los otros dónde quedan?. (2014, 23 de septiembre. Entrevistado por Merlano, L., Barrancabermeja)

Cada una de las percepciones están alineadas con la idea de un desarrollo desde la visión económica, que para Sergio Boisier (2010) es lo que comúnmente se ha hecho en la historia: asociar el desarrollo con la premisa del crecimiento económico, desconociendo con esto el planteamiento de otros desarrollos 
definidos por las comunidades en sus territorios, que con sus propios recursos, incluso con su mano de obra, su técnica y su innovación, les permita la satisfacción de sus necesidades, pero especialmente su libertad, su crecimiento y las capacidades del ser. En conclusión, desde lo planteado en la política pública, es una visión más economicista que no recoge elementos del desarrollo humano.

\subsection{La plataforma de empleo como herramienta para evitar la intermediación de laboral en Barrancabermeja}

En muchos casos durante las entrevistas se evidenciaron quejas por el manejo que se le ha dado a la plataforma de empleo; algunos la defienden mientras otros tienen reparos al respecto. Para la mayoría de los entrevistados del Comité está claro que la plataforma del Sena fue la única al inicio, así lo constata Alba Luz Amaya de Ecopetrol: "el SENA era la única entidad que estaba autorizada por el Gobierno Nacional para hacerlo y de eso hace 25 años" (2014, 19 de septiembre. Entrevistado por Merlano, L., Barrancabermeja). En ese mismo sentido opina Cristina Arena: "La plataforma del SENA era la única porque así lo determinaba la ley y le dieron esa potestad al SENA, y la experiencia fue dura, en la medida que las personas desconocían o decían desconocer los modos de operar en la plataforma" (2014, 23 de septiembre. Entrevistado por Merlano, L., Barrancabermeja).

Esto permitió que el SENA se convirtiera en blanco de críticas, y aunque los entrevistados reconocen su labor, argumentan que se han presentado fallas, "cosas que se han salido de control, la han hackeado en oportunidades, el contratista la ha manipulado de una manera que genera inconformidades con los trabajadores", (Adrián Rodríguez, 2014, 23 de septiembre. Entrevistado por 
Merlano, L., Barrancabermeja). Incluso hay quienes aseguran que las personas no saben utilizar la plataforma y que esto también genera inconvenientes en las postulaciones para acceder al trabajo:

Dicen que es una mano negra allá en el SENA que escoge los que entran y los que no entran, primero eso, segundo que la plataforma no es amigable, la plataforma no es sencilla, la plataforma lo muerde a uno, es decir cuando uno entra no es sencilla de consultar, ni es sencilla para uno postularse, tercero que las vacantes del SENA son muy al pie de la letra, entonces hay que saber cómo postularse. (Angélica Suárez, 2014, 18 de septiembre. Entrevistado por Merlano, L., Barrancabermeja)

Algunas de las quejas más reiterativas tienen que ver con la supuesta manipulación de la plataforma. Algunos miembros del Comité dicen que esto ha permitido que las personas interesadas en postularse paguen para presentarse a las pocas vacantes que se generan en la web:

...cuando hay proyectos buenos la postulación vale entre 200 a 300 mil pesos, entonces se postula esa persona y siempre con la expectativa que va a entrar, cuando no entra, a esa persona se le perdieron los 200 mil pesos. (Ernesto Arias, 2014, 20 de septiembre. Entrevistado por Merlano, L., Barrancabermeja) Comunicación personal, septiembre de 2014)

...es un hacker que tenemos ahí metido y no es el único, hay varias salas de internet aquí como 2 o 3 que venden las postulaciones así, entonces eso va en contra de la credibilidad y de la plataforma, es un proceso que hemos llevado a fiscalía pero no nos han prestado atención y la verdad eso va en detrimento de la plataforma. (Angélica Suárez, 2014, 18 de septiembre. Entrevistado por Merlano, L., Barrancabermeja)

Una de las situaciones que han identificado en la plataforma de empleo del SENA tiene que ver con la selección de personal. Para algunos es claro que ésta la realiza el empresario y no la página web; aseguran que en muchas ocasiones las personas del común no tienen claro el proceso lo cual ha generado inconformidades: 
...la agresión es en contra del SENA y no es así, es decir se pueden postular 1.000 personas y el contratista es el que decide a quien contrata y así debe ser, yo eso si lo defiendo, eso no puede ser que sea ni un sindicato, ni una asociación, ni Ecopetrol, ni un contratista o los empresarios de la ciudad no, el que paga el salario es el que debe decidir quién es el que entra a trabajar en su empresa. (Alba Luz Amaya, 2014, 19 de septiembre. Entrevistado por Merlano, L., Barrancabermeja)

...siempre se reitera que el dueño del proceso de selección es el contratista, lo que hace el servicio público de empleo es remitirle candidatos pero el contratista es el que hace el proceso de selección; la idea es hacerlo en un ambiente de transparencia, que todos tengan la misma información, el mismo acceso. (Adrián Rodríguez, 2014, 18 de septiembre. Entrevistado por Merlano, L., Barrancabermeja)

Algunas irregularidades denunciadas se relacionan con los horarios en los que se hacían públicas las postulaciones: horas no laborales, tipo 11 ó 12 de la noche. Frente a esto se generaron acuerdos para que las postulaciones se realizaran en horarios laborales y su divulgación con anticipación de 24 horas para lograr la participación de la comunidad interesada. Además, con la intervención del Ministerio de Trabajo en el tema se crearon otras agencias de empleo en la ciudad. Al respecto los miembros del Comité tienen muchas expectativas positivas y otros no guardan esperanza:

Es una de las mejores prácticas que tenemos en la ciudad en tema de intermediación y colocación, pues una forma trasparente a la cual yo accedo a una vacante laboral, postulo mi hoja de vida, postulo mi perfil, con las dos agencias que existen en la ciudad yo puedo decidir si me postulo o no a esa vacante pues en ambas la plataforma es fácil de manejar pero se puede mejorar, pero para mí son muy buenas las agencias. (Darlinson Rendón, 2014, 18 de septiembre. Entrevistado por Merlano, L., Barrancabermeja)

...la gente ha creado confianza en Cafaba raíz del comportamiento que han tenido los funcionarios porque les han ofrecido una oferta de empleo diferente, una capacitación diferente, un personal humano 
que psicológicamente prepara al joven para la entrevista y el Sena no tenía eso. (Pedro Barrera, 2014, 22 de septiembre. Entrevistado por Merlano, L., Barrancabermeja)

Sobre este tema, algunas personas consideran que el problema no es la herramienta tecnológica; es la falta de empleo, es la necesidad de generar otra dinámica económica, es abrir espacios para que otros sectores tengan cabida, incluso dentro de la plataforma virtual diferentes a la industria petrolera, es formar a las personas y ganarse la confianza por el manejo transparente de los procesos de vinculación, es hacer un trabajo social con las comunidades. Otro aspecto que señaló Ernesto Arias de la USO como necesario es "hablar con las personas que son potencialmente laborales, explicarles que se debe hacer, generar oportunidades y respetar las postulaciones" (2014, 20 de septiembre. Entrevistado por Merlano, L., Barrancabermeja).

\subsection{Divulgación y comunicación de la Política Pública de empleo en Barrancabermeja}

La estrategia de comunicación y divulgación está enmarcada dentro del Acuerdo 005 de 2008 y del Gran Acuerdo Social en el pilar de Talento Humano que se pactó entre las organizaciones sociales y las entidades públicas para generar un ambiente transparente. Con esto se busca que la comunidad participe y se postule a las vacantes, pero que además estén informados para que el proceso sea abierto:

El objetivo es contrarrestar todas esas inconformidades en la población respecto al manejo de la divulgación de empleo, el acuerdo es que 24 horas antes que el empleo se publique en la agencia, debió hacerse una divulgación previa en medios: televisión, radio e internet. (Adrián Rodríguez, 2014, 18 de septiembre. Entrevistado por Merlano, L., Barrancabermeja) 
Sin embargo, como lo indica el mismo Adrián Rodríguez, la divulgación no ha sido suficiente, principalmente por falta de recursos para pagar la publicidad a través de medios de comunicación locales. Según lo acordado en la Política Pública, el Artículo 12 menciona la necesidad de crear una estrategia de comunicación que permita sensibilizar, informar, convocar e incorporar el mayor número de entidades, empresas y actores sociales para que contribuyan en la implementación de la PP. Igualmente considera la necesidad de diseñar una estrategia comunicativa preventiva para la inmigración de mano de obra no calificada, con el objetivo de evitar que llegue personal de otras regiones a la ciudad. Pese a esto, el manejo que se le ha dado a la divulgación de los procesos en la política pública sigue siendo negativo:

Desde un comienzo se había hablado que ellos llevaban este mensaje a través de los medios de comunicación, lo hicieron y después ya lo abandonaron, ya casi no se da, la otra idea era socializar a través de letreritos en las carteleras, ya sea dentro y por fuera de la institución, ya casi no lo están colocando, o lo colocan muy tarde, donde casi la gente no se entera. (Armando Vargas, 2014, 24 de septiembre. Entrevistado por Merlano, L., Barrancabermeja)

...yo creería que falta, en la televisión local, en los medios electrónicos, pero hay una dificultad y es que no todo el personal maneja sistema electrónico, no tienen correo y no todo el mundo maneja eso. Entonces yo creería que aparte de educar a los trabajadores también hay que implementar otros medios para poder que sea más conocido el tema de las vacantes y así darles mayor oportunidad a los trabajadores (Ernesto Arias, 2014, 20 de septiembre. Entrevistado por Merlano, L., Barrancabermeja)

....Eso es un problema que dese al principio hemos tenido la socialización y divulgación, porque hay empresas que amarran la información porque no les conviene, porque ya viene con el personal del político que le adjudicó el contrato, y nos vemos a gatas para que esas empresas cumplan voluntariamente con el acuerdo que tenemos en la mesa pública de empleo es un trabajo arduo pero hay que hacerlo. (Pedro Barrera, 2014, 22 de septiembre. Entrevistado por Merlano, L., Barrancabermeja) 
Otros miembros del Comité de Política Pública, consideran que la divulgación que se le da es más que suficiente, pero mencionan otros problemas que son ajenos a este punto:

...el problema no es la difusión, el problema es el canal de búsqueda de los trabajadores, si yo tengo un canal de búsqueda formal y estoy hablando formal centro de empleo ahora, SENA, si las personas deciden apostarle al canal formal lo pueden hacer, pero es que las personas y eso lo dice la encuesta hogares, solamente el $13 \%$ de las personas en 2013 buscaba empleo a través de medios formales, el problema no es la divulgación, el problema es el método o el canal de búsqueda de las personas. (Diana Estupiñán, 2014, 23 de septiembre. Entrevistado por Merlano, L., Barrancabermeja)

Yo creo que es excelente lo que nosotros hacemos y yo creo que es ejemplo, es una consecuencia a los problemas que se generaron al comienzo, entonces al comienzo los contratistas ponían o publicaban sus vacantes en horarios fuera de oficina, manipulaban esa herramienta, eso es un producto del Gran Acuerdo Social, eso es un producto del pilar de Talento Humano, ahí se definió que las vacantes se iban a anunciar, llegó el Ministerio a decir eso es ilegalidad, eso es intermediación y lo defendimos, lo defendimos con uñas y dientes ante el ministerio, porque le dijimos NO, nosotros somos los únicos que salimos y le contamos a la gente..., eso es una forma democrática de socializar la información relacionada con el empleo y la dinámica que se genera. (Alba Luz Amaya, (2014, 19 de septiembre. Entrevistado por Merlano, L., Barrancabermeja)

Aun existiendo dentro del Acuerdo 005/2008 un artículo que precisa el lineamiento para la divulgación y la comunicación, existen puntos de discusión que demuestran las fallas que ha tenido su ejecución.

Las inconformidades evidencia los problemas que se han presentado para posicionar a la PP en el contexto local; no hay claridad sobre una estrategia de comunicación que impacte en los diferentes actores y entidades. Esto dificulta la participación, la información y permite la creación de imaginarios negativos que 
enlodan la gestión y coordinación de la Política pública. Para esto es indispensable que el Comité diseñe en la política una estrategia de comunicación que dé cuenta de las acciones desarrolladas, lo logrado hasta el momento, su apuesta, entre otros, para mejorar la percepción de la ciudadanía e impulsar la idea que con esta PP se propende no sólo por defender la mano de obra local sino por dinamizar la economía y generar desarrollo local para el bienestar de los barranqueños. 


\section{CONCLUSIONES Y RECOMENDACIONES}

A manera de conclusión se retomaron los resultados obtenidos en esta investigación, especialmente, para dar cuenta del objetivo que tuvo el presente trabajo de analizar la política pública a la luz de las percepciones de los diversos actores del Comité Municipal de la Política Pública de Empleo en Barrancabermeja sobre la defensa de la mano de obra local para la generación del desarrollo local.

En Barranca aunque existe una política pública regulatoria desde el año 2008, particularmente se evidencia una problemática social que se agudiza con los altos índices de desempleo y subempleo revelados por la Encuesta de Hogares 2013 realizada por el Centro de Estudios Regionales (CER) y las estadísticas regionales y nacionales comparadas, como se representa a continuación:

Tabla 7. Cuadro comparativo según cifras del Fenómeno de Empleo en Barrancabermeja

\begin{tabular}{|l|l|l|l|l|l|l|l|l|l|}
\hline $\begin{array}{c}\text { Barranca/ja } \\
\text { Vs B/ga y } \\
\text { Nación } \\
\text { (2007-2013) }\end{array}$ & $\begin{array}{c}\text { Local } \\
2007\end{array}$ & $\begin{array}{c}\text { B/ga } \\
2007\end{array}$ & $\begin{array}{c}\text { Nación } \\
2007\end{array}$ & $\begin{array}{c}\text { Local } \\
2011\end{array}$ & $\begin{array}{c}\text { B/ga } \\
2011\end{array}$ & $\begin{array}{c}\text { Nación } \\
2011\end{array}$ & $\begin{array}{l}\text { Local } \\
2013\end{array}$ & $\begin{array}{l}\text { B/ga } \\
2013\end{array}$ & $\begin{array}{c}\text { Nación } \\
2013\end{array}$ \\
\hline Ocupados & N.D. & $51,2 \%$ & $51,2 \%$ & $43.5 \%$ & $64 \%$ & $56,8 \%$ & $39,1 \%$ & $\begin{array}{l}63,3 \\
\%\end{array}$ & $58,2 \%$ \\
\hline Desempleo & $21,2 \%$ & $9,3 \%$ & $11,1 \%$ & $16.2 \%$ & $9.6 \%$ & $10,8 \%$ & $19.9 \%$ & $9.4 \%$ & $9.6 \%$ \\
\hline Subempleo & N.D. & $36,3 \%$ & $34,9 \%$ & $24.1 \%$ & $\begin{array}{l}34.8 \\
\%\end{array}$ & $31,5 \%$ & $26,0 \%$ & $\begin{array}{l}34.7 \\
\%\end{array}$ & $29,3 \%$ \\
\hline
\end{tabular}

Fuente: Dane 2007-2011-2013 - CER EHB 2011-2013

En la actualidad, según declaraciones del gobernador de Santander en la W Radio en marzo de 2016, Didier Tavera Amado, informó que el índice de desempleo en el puerto petrolero está en el 30\%, debido a los bajos precios del 
petróleo y el fenómeno del niño, situación que demuestra aún más la grave situación de empleo en la ciudad que ha llevado a la administración municipal exigirle al gobierno nacional atienda la petición de declarar emergencia económica en Barrancabermeja.

Esta investigación, permite dar cuenta de una compleja situación de empleo por la que atraviesa la ciudad de Barrancabermeja, en la que la política pública de empleo no ha respondido a la demanda de la mano de obra local cesante y a la generación de oportunidades laborales para la comunidad, por cuanto, la empresa petrolera no ha logrado absorber la gran mano de obra que existe en el puerto, esta afirmación se hace a partir de la información recolectada en campo.

Las expectativas que la industria del petróleo genera en las comunidades son amplias y no satisfacen en iguales proporciones sus realidades sociales. E proceso extractivo generalmente implica obtener jugosas ganancias a partir de inversiones muy pequeñas en términos de trabajo y acceso a la tierra, que "casi siempre crea condiciones de pobreza y por su mismo carácter es incapaz de propiciar el bienestar continuado y el crecimiento económico, tan anhelado por la economía convencional, en las áreas de las cuales se obtienen los bienes ambientales extraídos" (Angulo 2010 p. 16). Como lo plantean Isaza (1991) y Avellaneda (1998) para el caso petrolero, "las ganancias generadas a raíz de la extracción no han sido reinvertidas de la manera adecuada en los renglones necesarios y por lo tanto ha sido imposible dar cuenta de un mejoramiento real en las condiciones de vida de los habitantes de las regiones donde se ha logrado extraer el recurso" (Angulo 2010).

Por esta razón, los representantes del Comité de la Política Pública de Empleo de la ciudad reclaman una política pública que genere oportunidades laborales para la sociedad porteña, que involucre y potencie nuevos sectores 
productivos, distintos a la dinámica petrolera. Para esto, es necesario plantearse un modelo de desarrollo local que cuente con la participación activa de las fuerzas vivas de la ciudad para trazar una visión de territorio compartido y sino simplemente, se realizó una política púbica de arriba abajo (top down).

Se requiere reestructurar el Comité de Política Pública de Empleo y por tanto a sus miembros para generar nuevas ideas, debido a que desde la creación del Comité ha estado conformado por los mismos participantes, y se demuestra que no hay el seguimiento a las acciones encaminadas a minimizar los problemas de empleo de la ciudad, no se realiza una evaluación y control para mejorar la PP. No se evidencia una coordinación acertada entre los representantes, una participación real y valedera en la toma de decisiones. Para esto es preciso rotar o cambiar a los representantes que lo integran para que reciban nuevos aportes que le den a la PP un manejo distinto. Ahora deberán ejercer un control eficiente, empresarial, gubernamental y civil para la puesta en marcha de la PP y con la renovación se podrán implementar acciones de seguimiento, impacto e incidencia en los sectores productivos.

La actual apuesta de política pública de empleo, responde más a un modelo de desarrollo economicista, que en nada se parece al modelo referido en el planteamiento del Acuerdo 005 de 2008, con el que se busca "identificar los problemas prioritarios y sus alternativas de solución, de tal manera que la planificación y gestión municipal se orienten efectivamente a la satisfacción de las necesidades de la población. Pero también, al desarrollo local integral". En este sentido, es indispensable que los actores locales impulsen un desarrollo local desde una perspectiva distinta, porque no puede considerarse que haya éxito económico sin tener en cuenta la vida de los individuos que conforman la comunidad. El desarrollo es entonces el desarrollo de las personas de la sociedad. De acuerdo con Sen (1999) es indispensable que se generen opciones 
para que las personas tengan acceso al trabajo; eso permitirá la generación de ingresos a los individuos para satisfacer otras necesidades para su propio desarrollo. Con esta idea, Sen (1997) señala que la pobreza y el desempleo coartan la forma en que los individuos pueden disfrutar y apreciar; y representan severas violaciones a la libertad.

En la investigación se plantea un segundo objetivo, al respecto, durante el proceso de implementación de la política pública, no se han obtenido resultados concretos para la generación de empleos. Aunque, se evidencian acciones para defender la mano de obra local, los esfuerzos no son suficientes para crear nuevas fuentes de empleo, ajenas a la dinámica petrolera. Con esto resulta difícil que las estrategias puestas en marcha den solución a la problemática que tanto aqueja a los barranqueños para mejorar sus condiciones de vida dentro del desarrollo local para el empleo.

Es claro para los miembros del Comité de Política Pública, lo que significa defensa de la mano de obra local, concepto que está definido dentro de los relatos de los entrevistados, pero se destaca, que algunas de las acciones implementadas en la ejecución de la PP han tenido falencias, como es el caso de la plataforma pública del Sena y el certificado de territorialidad, con las que se presentaron quejas sobre su manejo "se encontraron en las fuentes testimoniales que la plataforma sufrió ataques de hackers que ocasionó problemas y desconfianza en la ciudadanía". De igual forma en varias de las entrevistas manifestaron "que los ciudadanos pagaban para las postulaciones en las vacantes ofrecidas". Esta práctica de alguna manera afecta el imaginario colectivo acerca de la transparencia y la efectividad de la PP en la consecución de resultados y genera una percepción negativa en los ciudadanos que buscan participar en los procesos vacantes. 
Es preciso recordar que aunque la PP obedece a un necesidad de la comunidad barranqueña por defender la mano de obra local, específicamente en la industria petrolera, su puesta en marcha permitió entender que es necesario apostarle a otros renglones económicos; obtener información sobre la situación de empleo de la ciudad y el talento humano; emprender capacitaciones y formación para los ciudadanos como herramienta para la generación de competencias, procurar una intermediación digna y decente en la que se premie la meritocracia en la selección de vacantes.

La desconfianza sobre las acciones implementadas que existe entre los trabajadores, agremiaciones, sindicatos y representantes de la comunidad que hacen parte de la mesa del Comité, extiende la deslegitimación de la política pública, generando un panorama que no es alentador para solucionar los problemas de empleo de la ciudad, ni al corto ni al mediano plazo. Para los integrantes del Comité, a la mano de obra local se le estigmatiza por considerar que el barranqueño no está lo suficientemente capacitado y por estar rotulado dentro de una cultura contestataria. Es imprescindible que la PP sea incluyente, que involucre y genere más participación de la sociedad para que sea ella misma quien valide las estrategias y acciones emprendidas en la búsqueda de nuevas opciones laborales para las personas establecidas en el territorio.

El Comité de política pública es gerenciado de forma vertical, direccionado desde la institucionalidad. Se evidencia la falta de coordinación para trabajar con cada estamento representante; no se tienen objetivos claros y acciones que permitan avanzar hacia una PP que dé cuenta de las necesidades laborales de las comunidades y que entregue resultados para generar bienestar común a los habitantes del puerto petrolero. 
Aunado a la falta de la estrategia de comunicación, no se encuentra evidencia que exista, por lo tanto, como conclusión se requiere implementar una fuerte estrategia de comunicación para reforzar una imagen positiva entre los ciudadanos de lo que se realiza a través de la PP, en donde se generen campañas de divulgación institucionales por la transparencia, la confianza y el compromiso por mejorar las condiciones laborales de las comunidades. Al respecto, Eugene Bardach expone un modelo compuesto por ocho pasos para el análisis de las políticas públicas; específicamente sobre la comunicación el autor asegura que es indispensable contar la historia... "en términos lo suficientemente sencillos y realistas como para que ese "cualquiera" sea capaz de seguir adelante con la tarea de la educación pública y democrática" (1998 p. 70). En tanto, una política pública que no se comunica ni difunde suficientemente presentará dificultades para su aceptación y adaptación social en el territorio.

En las fuentes secundarias y las entrevistas se evidencia que no hay planes, programas, proyectos o información con datos que demuestren que hay un estímulo a las a las empresas locales y foráneas para que se dé preferencia a la mano de obra local. En tanto, se concluye que es necesario caracterizar a las empresas que son fuente de empleo para obtener información veraz y tomar decisiones de política pública; atendiendo a que son situaciones desiguales, dispares y contradictorias a un desarrollo posible para todos son y que se generen nuevas estrategias como lo señala García (2004, p. 144).

Finalmente, se concluye que la política pública no está generando desarrollo local, porque los resultados así lo demuestran, ejemplo de ello es el alto nivel de desempleo, por el contrario, ha generado todo tipo de problemas sociales, entre ellos delincuencia, robo, consumo de SPA, que en nada contribuyen para que las comunidades puedan potenciar sus capacidades en el territorio, y cubrir sus necesidades básicas, tal como lo plantea Alburquerque (citado por García, 2004, 
p. 146) que es un proceso de transformación de la economía y la sociedad locales "para el aprovechamiento más eficiente y sustentable de los recursos endógenos existentes, mediante el fomento de las capacidades de emprendimiento empresarial locales y la creación de un entorno innovador en el territorio" y en Barrancabermeja el ethos cultural es el mismo, "seguir dependiendo de la industria petrolera".

Brevemente se plantean las siguientes recomendaciones:

Rediseñar de las acciones de la política pública de empleo de la ciudad para avanzar en estrategias que den solución a la problemática de trabajo que enfrentan las personas en el territorio, de manera que esto contribuya en mejorar las condiciones de vida de los ciudadanos. De acuerdo a lo planteado en el Capítulo 3 (Marco Conceptual) sobre PP, es recomendable hacer cambios y modificaciones a las PP, cuando no se logran los resultados esperados.

Trazar un modelo de desarrollo del territorio no sólo basado en el crecimiento económico, sino en las capacidades del ser, en el que se tenga en cuenta sus circunstancias culturales, políticas, administrativas, sociales y económicas, dando un uso responsable a los recursos del territorio para permitir la generación de riquezas para sus comunidades. En este modelo es indispensable la participación de la sociedad para impulsar de manera colectiva lo local en la consecución de su propio desarrollo.

Desarrollar estrategias de buen gobierno para que las acciones implementadas en el proceso de la PP sean transparentes, generen confianza en la ejecución, permitan la vinculación de la sociedad no sólo para defender la mano de obra local sino para trabajar mancomunadamente por el desarrollo local, de acuerdo a su visión compartida del territorio. 


\section{REFERENCIAS BIBLIOGRÁFICAS}

Aguilar, L. (1993). Implementación de las Políticas. Estudio Introductorio. México: Miguel Ángel Porrúa grupo editorial, [en línea], disponible en http://www.inap.mx/portal/images/RAP/la\%20implementacion\%20de\%20las\%20 politicas.pdf

(2008). "Marco para el Análisis de las Políticas Públicas", [en línea], disponible en https://docs.google.com/viewer?a=v\&pid=sites\&srcid=ZGVmYXVsdGRvbWFpbn xhbmFsaXNpc3BwdWd8Z3g6N2I1YzYxNzVjOGFhYzEzOQ

Alburquerque, F. (2004). Desarrollo económico local y descentralización en América Latina. Revista de la CEPAL (82) 157-171.

Alcaldía Municipal de Barrancabermeja. (2008). Plan de Desarrollo (2008-2011) Barrancabermeja, donde el amor es clave, [en línea], disponible en http://cdim.esap.edu.co/BancoMedios/Documentos\%20PDF/barrancabermeja\% 20-\%20santander\%20-\%20pd\%20-\%202008\%20-

\%202011\%20(p\%C3\%A1g\%20\%20-\%2011.654\%20kb).pdf

(2012). Plan de Desarrollo (2012-2015) Barrancabermeja, ciudad Futuro, [en línea], disponible https://www.barrancabermeja.gov.co/institucional/Nuestros\%20Planes/Plan\%20 de\%20Desarrollo.pdf

Almario M. (2012, 26 de enero). "Marcharon en contra de la política pública de empleo en Barrancabermeja", en vanguardia.com [en línea], disponible en http://www.vanguardia.com/santander/barrancabermeja/140796-marcharon-encontra-de-la-politica-publica-de-empleo-en-barrancaber

Álvarez, J. F. (2001). Capacidades, libertades y desarrollo: Amartya Sen. En Máiz, R. (comp.) Teorías políticas contemporáneas. (pp.381-396). Valencia: Tirant lo Blanch.

Angulo, R. (2010). Economías extractivas y desarrollo sostenible: análisis y reflexiones de sus relaciones, a partir de la explotación petrolera del Putumayo. [Tesis de Maestría]. Bogotá: Universidad Nacional de Colombia.

Antunes, R. (2000). Los sentidos del trabajo: ensayo sobre la afirmación y la negación del trabajo (2a ed.). São Paulo: Boitempo.

American Psychological Asociación (2002, Manual de estilo de publicaciones de la American Psychological Associatión, México: el manual Moderno.

Avellaneda, A. (1998). Petróleo, colonización y medio ambiente en Colombia. Bogotá: Ecoe ediciones. 
Ávila, C. (2009). Dinámica de la acumulación de capital humano en Yopal (Casanare).Apuntes del Cenes. 27 (6) 261-297.

Banco Mundial (2013). "Informe sobre el desarrollo mundial 2013: Empleo. Panorama general" [en línea], disponible en http://siteresources.worldbank.org/EXTNWDR2013/Resources/82580241320950747192/8260293-1322665883147/Overview_Spanish.pdf

Barañano, A. (2005) Diccionario de relaciones interculturales diversidad y globalización. Madrid: Editorial Complutense.

Bardach, E. (1998). Los ocho pasos para el análisis de políticas públicas. Un manual para la práctica. García-Junco D. (trad.) Mexico: Cide.

Boisier, S. (1999) Desarrollo Local ¿De qué estamos hablando?, Santiago de Chile: Cepal, ilpes.

Borges, L. \& Yamamoto, O. (2004). "El Mundo del Trabajo", [en línea], disponible en http://xa.yimg.com/kg/groups/24137146/956932885/name/Texto+1++Mundo+do +trab.+(Borges+e+Yamamoto).pdf

Centro de Estudios Regionales de Magdalena Medio (CER). Observatorio Mercado Laboral del Magdalena Medio (OML) (2013a) Encuesta a Hogares de Barrancabermeja. Barrancabermeja: CER-OML.

(2013b). "Caracterización de la demanda de talento humano para los sectores comercio, servicios, construcción y transporte", [en línea] disponible en http://200.114.17.148/flex/Documentos/Caracterizaciones/Documentodecaracter izaci\%C3\%B3ndelademandadeltalentohumano.pdf

(2011) Modulo de encuesta a Hogares de Barrancabermeja. Barrancabermeja: CER-OML [en línea] disponible en http://cer.org.co/index.php/observatorios/mercadolaboralobs/encuesta-hogares2011/53-cartilla-encuesta-de-hogares-2011

(2012). Dinámica demográfica de la ciudad de Barrancabermeja. [en línea] disponible en https://www.barrancabermeja.gov.co/institucional/Indicadores\%20Barrancaberm eja/Estudio\%20sobre\%20la\%20Din\%C3\%A1 mica\%20Demogr\%C3\%A1fica\%20 de\%20la\%20ciudad\%20de\%20Barrancabermeja.pdf

Comisión Económica para América Latina y el Caribe (CEPAL). (2009) Políticas para la generación de empleo de calidad. Santiago de Chile: ONU. Cepal, [en línea] disponible en

de http://repositorio.cepal.org/bitstream/handle/11362/1068/S0900483_es.pdf?sequ ence $=1$ 
(2012). Cambio estructural para la igualdad: Una visión integrada del desarrollo, propuesta estratégica del organismo para los próximos años. El Salvador: Cepal, [en línea] disponible en http://www.cepal.org/cgibin/getprod.asp?xml=/pses34/noticias/documentosdetrabajo/4/47424/P47424.x $\mathrm{ml} \& \mathrm{xs}=/$ pses34/tpl/p38f.xsl\&base=/pses34/tpl/top-bottom.xsl

Centro de Investigación y Educación Popular (CINEP) (2012) Informe Especial: Minería, Conflictos Sociales y Violación de Derechos Humanos en Colombia. Programa por la Paz. Bogotá: Cinep-PPP. [en línea] disponible en http://www.alainet.org/images/IE_CINEP_octubre_2012.pdf

Cuervo, J. (2007). Las políticas públicas: entre los modelos teóricos y la práctica gubernamental (una revisión de los presupuestos teóricos de las políticas públicas en función de su aplicación a la gestión pública colombiana). En: Cuervo, J. (Ed.). Ensayos sobre políticas públicas. (pp.65-95). Bogotá: Universidad Externado de Colombia.

Cuervo, L. (1999). Desarrollo económico local: leyendas y realidades. Territorios, ( ) 924. Recuperado de http://redalyc.org/articulo.oa?id=35700102

Da Rosa, S., Chalfin, M., Baasch, D., \& Soares, J. (2011). "Sentidos y significados del trabajo: un análisis con base en diferentes perspectivas teórico-epistemológicas en Psicología". Universitas psychologica. 10 (1) 175-188. [en línea] disponible en http://www.scielo.org.co/scielo.php?pid=S1657-

92672011000100015\&script=sci_arttext

De la Garza, E. (2001). Problemas clásicos y actuales de la crisis del trabajo. El Futuro del Trabajo. Buenos Aires: CLACSO.

Departamento Administrativo Nacional de Estadística (DANE) (2015). Gran Encuesta Integrada de Hogares. [en línea], disponible en http://www.dane.gov.co/index.php/esp/component/content/article/110boletines/encuestas-politicas-y-culturales/4565-mercado-laboral

(2005) Demografía y población. Proyecciones de población [en línea], disponible en http://www.dane.gov.co/index.php/poblacion-y-demografia/proyecciones-depoblacion

Escobar, A. (1998) La invención del Tercer mundo. Construcción y deconstrucción del desarrollo. Bogotá: Grupo Editorial Norma.

Etzioni, A. (1973), "La exploración combinada: un tercer enfoque en la toma de decisiones", Roqueñi M. (Trad.), en: Aguilar L. (1992). La hechura de las políticas públicas. (pp. 265-282). México: Miguel Ángel Porrúa grupo editorial

García, L. (2004). "El desarrollo local como estrategia de desarrollo emergente en un mundo globalizado. Presente y Pasado. Revista de Historia. 9 (17) 137-152. 
Recuperado

http://www.saber.ula.ve/bitstream/123456789/22981/2/articulo8.pdf

García, M. (2006). Conflicto, poderes e identidades en el Magdalena Medio, Barrancabermeja: ciudad en permanente disputa. Bogotá: Colciencias, Cinep.

Google (s.f). Mapa municipio de Barrancabermeja, [en línea], disponible en https://www.google.com.co/maps/place/Barrancabermeja,+Santander/@7.05972 46,-

73.8690052,14z/data=!4m2!3m1!1s0x8e42eca8af70acad:0xcfa9ac026f4a1cd6

Gómez, J. (2013) Creencias y percepciones acerca de las posibilidades laborales de las personas con discapacidad intelectual [Tesis Doctoral] España: Universidad de Alicante.

Gorofoli, G. (1994). Modelos Locales de Desarrollo (2da Edición). Milán: Franco Angeli.

Gudynas, E. (2013). Extracciones, Extractivismos y Extrahecciones. Un marco conceptual sobre la apropiación de recursos naturales. El Observatorio del Desarrollo, CLAES. [en línea] disponible en http://ambiental.net/wpcontent/uploads/2015/12/GudynasApropiacionExtractivismoExtraheccionesOde D2013.pdf

International Human Rights Internship Program y Asian Forum for Human Rights and Development (Forum-Asia). (2000) Círculo de Derechos, una herramienta de entrenamiento para el activismo en defensa de los derechos económicos, sociales y culturales. Washington: IHRIP y Forum Asia.

Jolly, J. (2012). “La interdeterminación entre territorio, territorialidad y territorialización de las políticas públicas: hacia una nueva propuesta de esquema para el análisis de las políticas públicas en el territorio", en XVII Congreso Internacional del CLAD sobre la Reforma del Estado y de la Administración Pública. Cartagena, [en línea] disponible en: http://www.dgsc.go.cr/dgsc/documentos/cladxvii/jollyjea.pdf

Kovács, I. (2005). El empleo flexible en Portugal: algunos resultados de un proyecto de investigación. La flexibilidad en el empleo: oportunidades y riesgos. Oeiras, Portugal: Celta.

London, S. \& Formichella, M.M. (2006), "El concepto de desarrollo de Sen y su vinculación con la Educación”, en Economía y Sociedad. XI (17) 17-32.

López, C.; Espinal, F. \& Menier, S. (2006). Impacto de la mano de obra haitiana en la economía dominicana. República Dominicana

LOWI, Th. (1964). "American Business and Public Policy Case Studies and Political Theory", en World Polities, XVI, pp. 677-715. 
Mejía, J. (2012). "Modelos de implementación de las políticas públicas en Colombia y su impacto en el bienestar social", en Analecta política. 2(3)141-164.

Michael Page. (2013). "Gas y petróleo, las industrias preferidas para trabajar por los ejecutivos", en Colombia, [en línea], disponible en http://michaelpage.com.co/productsApp_co/news/03/noticia03.html

Monnet, J. (1999). “Los casos de los Ángeles y la Ciudad de México”, en: Memorias del $V$ Seminario Internacional de la Red Iberoamericana de Investigadores sobre Globalización y Territorio. Toluca, México, [en línea], disponible en https://halshs.archives-ouvertes.fr/halshs-00007796/document

Muiños, B. (2002). Empleo y territorio: evaluación de la dimensión territorial de las políticas de empleo. [Tesis Doctoral].España: Universidad de Barcelona.

Murillo, F. (1995). Enfoques Metodológicos de Investigación en Ciencias Sociales. España: UAM, [en línea], disponible en http://www.uam.es/personal_pdi/stmaria/alenava/Docencia/DOCTORADO/PRIM ERA_PARTE_DOCS/ENFOQUES_METODOLOGICOS_J_MURILLO.pdf

Neffa, J. (2014). Actividad, empleo y desempleo. Conceptos y definiciones. Buenos Aires: Centro de Estudios e Investigaciones Laborales, [en línea], disponible en http://www.clacso.org.ar/libreria_cm/archivos/pdf_461.pdf

Negrete, R. (2013). "Capítulo 1: Derechos, minería y conflictos. Aspectos normativos", en: Garay, L. (Dir.) Minería en Colombia. Fundamentos para superar el modelo extractivista. (pp. 23-50). Bogotá: Contraloría General de la República.

Olea, M \& Casas, M. (2006). Derecho del Trabajo. Madrid: Ed. Thomson Civitas

Ordoñez, G. (2013). Manual de análisis y diseño de Políticas Públicas. Bogotá: Universidad Externado de Colombia.

Orellana, V. (2010). La responsabilidad social de las empresas multinacionales petroleras, Perenco Limited Colombia y Hocol S.A.: el aporte al desarrollo local del municipio de Yopal. [Trabajo de grado], Bogotá: Universidad Javeriana, Carrera de ciencia política.

Organización Internacional del Trabajo (OIT). (2015). "Informe sobre el Trabajo en el Mundo 2014 El desarrollo a través del empleo", [en línea], disponible en http://www.ilo.org/wcmsp5/groups/public/---dgreports/--dcomm/documents/publication/wcms_243965.pdf

(2013). "Nota conceptual de la OIT sobre la agenda de desarrollo post 2015", [en línea], disponible en http://www.ilo.org/wcmsp5/groups/public/---dgreports/--dcomm/documents/statement/wcms_206443.pdf 
Palomares, J. (s.f.). "Territorialización y Apropiación", [en línea], disponible en https://arqjespalfra.wordpress.com/4-territorializacion-y-apropiacion/

Patiño G. (2005), Citas y referencias bibliográficas. Bogotá: Pontificia Universidad javeriana.

Procuraduría General de la Nación. (2010). Trabajo digno y decente en Colombia Seguimiento y control preventivo a las políticas públicas. Bogotá: Procuraduría General de la Nación

Programa de las Naciones Unidas para el Desarrollo, PNUD. (2015). Repensar el trabajo por y para el desarrollo humano - Informe sobre Desarrollo Humano 2015. [en línea], disponible en http://hdr.undp.org/es/repensar-el-trabajo-por-y-para-eldesarrollo-humano

Pulido-Martínez, H. C. (2007). "Produciendo trabajadores modernos: conocimiento psicológico y el mundo del trabajo en el sur”. Universitas Psychologica. 6 (1) 2737.

Quivy (1997). Manual de Investigación en Ciencias Sociales. México D.F: Editorial Limusa S.A.

Real Academia Española (REA) (2014). [en línea], disponible en: http://dle.rae.es/?id=ZcqJYVW

Roth, A. (2002). Políticas públicas. Formulación, implementación y evaluación. Bogotá: Aurora

Sabatier, P. (1986). "Enfoques de arriba hacia abajo y de abajo hacia arriba en la investigación sobre implementación: un análisis crítico y propuesta de síntesis", en Periódico de políticas públicas. 6 (1)28-45.

Sen, A. (1997) Desigualdad y desempleo en el Europa Contemporánea. Revista Internacional del Trabajo. 116 (2) 169-187.

(1999) Desarrollo y Libertad. Editorial Planeta.

(2001) Capacidad y Bienestar, [en línea], disponible en http://www.chihuahua.gob.mx/atach2/codesoypc/uploads/Lecturas\%20de\%20Po 1\%C3\%ADtica\%20Social/Lecturas\%20sobre\%20Desarrollo\%20\%20Humano/Am artya\%20Sen/Capacidad\%20y\%20Bienestar.pdf

Servicio Nacional de Aprendizaje (SENA). (2007) Dirección General y Dirección de Empleo y Trabajo. Clasificación Nacional de ocupaciones. Versión 2007. [En línea] Recuperado https://cfsbusiness.files.wordpress.com/2012/09/cno_2007.pdf 
Vargas, Alejo. (2007). Fundamentos de políticas públicas. Bogotá: Departamento de Ciencia Política, Universidad Nacional de Colombia.

Vázquez, A. (1988). Desarrollo local. Una estrategia de creación de empleo. Madrid: Pirámide.

Velasco, J. \& Rocha, L. (2012) Una cadena de conflictos: Errores y aprendizajes de la actividad empresarial en Puerto Gaitán. Colombia: Cerac, [en línea], disponible en http://cerac.org.co/assets/pdf/Other\%20publications/CadenadeConflictos.pdf

Velásquez, R. (2009) Hacia una nueva definición del concepto "política pública". Desafíos. (10) 149-187.

W Radio. (2016, 3 de marzo), "Desempleo en Barrancabermeja llegó al 30\%” [en linea], en W Radio, Sanchez, J. (dir.), Grupo latino de radio S.L. (Prisa) y Caracol radio. Bogota [en linea], disponible en http://www.wradio.com.co/noticias/regionales/desempleo-en-barrancabermejallego-al-30/20160303/nota/3075315.aspx

\section{Lista de normas y convenios}

Colombia (2015), Código Sustantivo del Trabajo, Bogotá: Legis

Colombia (2015), Constitución política, Bogotá: Legis

Colombia, Congreso de la República (1961, 27 de marzo). "Ley 10 del 27 de marzo de1961 por la cual se dictan disposiciones en el ramo de petróleos", en Diario Oficial núm. 30.477, del 27 de marzo de 1961. Bogotá.

Colombia, Congreso de la República (1968, 31 de diciembre). "Ley 74 del 26 de diciembre de 1968, por la cual se aprueban los Pactos Internacionales de Derechos Económicos, Sociales y Culturales, de Derechos Civiles y Políticos, así como el protocolo Facultativo de este último, aprobados por la Asamblea General de las Naciones Unidas en votación unánime, en Nueva York, el 16 de diciembre de 1966”, en Diario Oficial núm. 32.682 de 30 de diciembre de 1968. Bogotá.

Colombia, Congreso de la República (1984, 17 de julio). "Ley 20 del 17 de julio de 1984 por la cual se reglamenta el ejercicio de la profesión de Ingeniero de Petróleos y se dictan otras disposiciones", en Diario Oficial núm. 36.768 del 17 de julio de 1984. Bogotá.

Colombia, Congreso de la República (1993, 22 de diciembre). "Ley 99 del 22 de diciembre de 1993 por la cual se crea el Ministerio del Medio Ambiente, se reordena el Sector Público encargado de la gestión y conservación del medio ambiente y los recursos naturales renovables, se organiza el Sistema Nacional 
Ambiental, SINA, y se dictan otras disposiciones.", en Diario Oficial núm. 41.146 del 22 de diciembre de 1993. Bogotá.

Colombia, Congreso de la República (2001, 8 de septiembre). "Ley 685 del 15 de agosto de 2001 por la cual se expide el Código de Minas y se dictan otras disposiciones", en Diario Oficial núm. 45.273 del 8 de agosto de 2001. Bogotá.

Colombia, Congreso de la República (2001, 21 de diciembre). "Ley 715 del 21 de diciembre de 2001, por la cual se dictan normas orgánicas en materia de recursos y competencias de conformidad con los artículos 151, 288, 356 y 357 (Acto Legislativo 01 de 2001) de la Constitución Política y se dictan otras disposiciones para organizar la prestación de los servicios de educación y salud, entre otros" en Diario Oficial núm, 44654 del 21 de diciembre del 2001. Bogotá.

Colombia, Congreso de la República (2013, 6 de diciembre). "Decreto número 2852 del 6 de diciembre de 2013 por la cual se reglamenta el Servicio Público de Empleo y el régimen de prestaciones del Mecanismo de Protección al Cesante, y se dictan otras disposiciones", en Diario Oficial núm. 48.996 del 6 de diciembre de 2013. Bogotá.

Colombia, Ministerio de minas y Energía (1986, 2 de mayo). "Decreto número 1412 del 2 de mayo de 1986, por la cual se reglamenta la Ley 20 de 1984, y se dictan otras disposiciones.", en Diario Oficial núm. 35.455 del 6 de mayo de 1986. Bogotá.

Colombia, Ministerio de Trabajo (2013, 15 de abril) "Decreto número 0722 del 15 de abril de 2013, por el cual se reglamenta la prestación del Servicio Público de Empleo, se conforma la red de operadores del Servicio Público de Empleo y se reglamenta la actividad de intermediación laboral", en Diario Oficial núm. 48762 del 15 abril de 2013. Bogotá.

Colombia, Corte Constitucional (2005,14 de abril), Sentencia (C-401), M.P.: Cepeda, M. Bogotá.

Colombia, Alcaldía municipal de Barrancabermeja (2009, 29 de julio). "Decreto número 223 del 29 de julio de 2009, por cual se crea y conforma el Comité Municipal de la Política de Empleo para Barrancabermeja". Barrancabermeja.

Colombia, Alcaldía municipal de Barrancabermeja (2013, 4 de abril). "Decreto número 080 del 4 de abril de 2013, por el cual el cual se establece el procedimiento para la expedición de la certificación para acreditar residencia a aquellas personas que residen en el territorio del área de influencia de los proyectos de exploración y explotación petrolera y minera en general, y que aspiren acceder a labores como mano de obra no calificada y calificada", Barrancabermeja.

Colombia, Alcaldía municipal de Barrancabermeja (2013, 7 de octubre). "Decreto número 220 del 7 de octubre de 2013, por el cual el cual se establece el procedimiento para la expedición del certificado de territorialidad, que acredita residencia en el municipio de Barrancabermeja". Barrancabermeja. 
Colombia, Concejo municipal de Barrancabermeja (1985, 12 de septiembre) "Acuerdo número 026 del 12 de septiembre de 1985, por medio del cual se crea el comité para protección del empleo y otras disposiciones". Barrancabermeja

Colombia, Concejo municipal de Barrancabermeja (2008, 6 de junio) “Acuerdo 005 del 6 de junio de 2008 por la cual se establece le política de empleo, generación de ingresos y defensa de la mano de obra barranqueña". Barrancabermeja.

Colombia, Municipio de Barrancabermeja- Ecopetrol- UTS-Fundesmag. (2012, 4 de diciembre) "Convenio de colaboración DHS núm. 5211713". Bogotá

Colombia, Ministerio del trabajo-Municipio de Barrancabermeja. (2013, 29 de agosto) "Convenio interadministrativo de colaboración núm. 315". Bogotá

Colombia, Municipio de Barrancabermeja- Cafaba. (2013, 29 de noviembre) "Convenio de colaboración núm. 1594-13". Bogotá

Organización Internacional del Trabajo (1998, 18 de junio) Declaración de la OIT relativa a los Principios y Derechos Fundamentales en el Trabajo". Ginebra

Organización de la Naciones Unidas (1948, 10 de diciembre). "Resolución 217 A (III), el 10 de diciembre de 1948. Declaración Universal de los Derechos Humanos, el Pacto Internacional de Derechos Económicos, Sociales y Culturales, el Pacto Internacional de Derechos Civiles y Políticos, y la Convención Americana sobre Derechos Humanos". Paris. 


\section{ANEXOS}

- Anexo 1. Formato de entrevistas (CD-ROM).

- Anexo 2. Cuadro de aciertos, desaciertos y retos que enfrenta la Política Pública de Empleo En Barrancabermeja (CD-ROM).

- Anexo 3. Acuerdos Municipales 005/2008 y 026/1985 (CD-ROM).

- Anexo 4. Decreto 223 de 2009, Decreto 080 de 2013, Decreto 220 de 2013, Decreto 0722 de 2013 y Decreto 2852 de 2013 (CD-ROM).

- Anexo 5. Cartillas Encuesta de Hogares 2011 y 2013 realizada por el CER (CD-ROM).

- Anexo 6. Planes de Desarrollo periodo de estudio 2008-2014. 